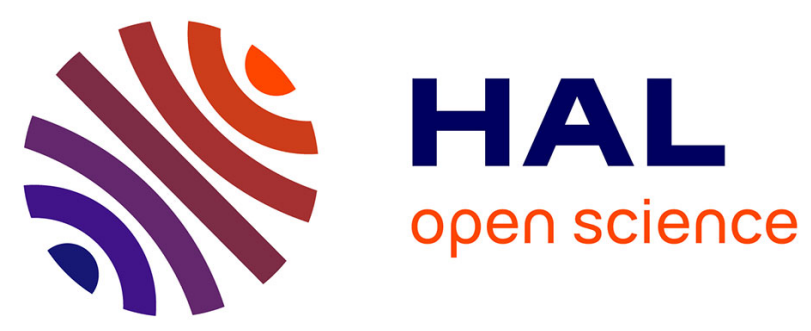

\title{
Driving mechanisms of Holocene coastal evolution in the Bonifacio Strait (Western Mediterranean)
}

Matteo Vacchi, Matthieu Ghilardi, Paolo Stocchi, Stefano Furlani, Veronica Rossi, Carla Buosi, Alessio Rovere, Sandro de Muro

\section{- To cite this version:}

Matteo Vacchi, Matthieu Ghilardi, Paolo Stocchi, Stefano Furlani, Veronica Rossi, et al.. Driving mechanisms of Holocene coastal evolution in the Bonifacio Strait (Western Mediterranean). Marine Geology, 2020, 427, 10.1016/j.margeo.2020.106265 . hal-03039386

\section{HAL Id: hal-03039386 https://hal.science/hal-03039386}

Submitted on 4 Jan 2021

HAL is a multi-disciplinary open access archive for the deposit and dissemination of scientific research documents, whether they are published or not. The documents may come from teaching and research institutions in France or abroad, or from public or private research centers.
L'archive ouverte pluridisciplinaire HAL, est destinée au dépôt et à la diffusion de documents scientifiques de niveau recherche, publiés ou non, émanant des établissements d'enseignement et de recherche français ou étrangers, des laboratoires publics ou privés. 


\section{Journal Pre-proof}

Driving mechanisms of Holocene coastal evolution of the Bonifacio Strait (Western Mediterranean)

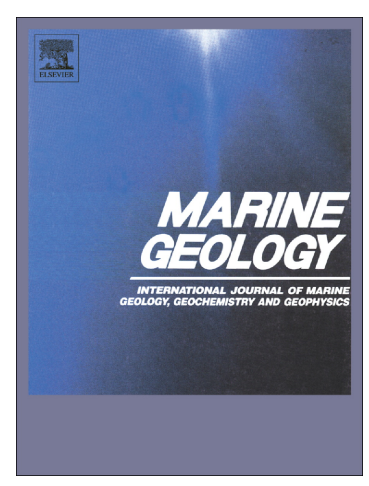

Matteo Vacchi, Matthieu Ghilardi, Paolo Stocchi, Stefano Furlani, Veronica Rossi, Carla Buosi, Alessio Rovere, Sandro De Muro

PII: $\quad$ S0025-3227(20)30153-5

DOI: $\quad$ https://doi.org/10.1016/j.margeo.2020.106265

Reference: $\quad$ MARGO 106265

To appear in: $\quad$ Marine Geology

Received date: $\quad 14$ April 2020

Revised date: $\quad 30$ May 2020

Accepted date: $\quad 7$ June 2020

Please cite this article as: M. Vacchi, M. Ghilardi, P. Stocchi, et al., Driving mechanisms of Holocene coastal evolution of the Bonifacio Strait (Western Mediterranean), Marine Geology (2020), https://doi.org/10.1016/j.margeo.2020.106265

This is a PDF file of an article that has undergone enhancements after acceptance, such as the addition of a cover page and metadata, and formatting for readability, but it is not yet the definitive version of record. This version will undergo additional copyediting, typesetting and review before it is published in its final form, but we are providing this version to give early visibility of the article. Please note that, during the production process, errors may be discovered which could affect the content, and all legal disclaimers that apply to the journal pertain.

(C) 2020 Published by Elsevier. 
Driving mechanisms of Holocene coastal evolution of the Bonifacio Strait (Western Mediterranean)

Matteo Vacchi ${ }^{1 *}$, Matthieu Ghilardi ${ }^{2}$, Paolo Stocchi $^{3}$, Stefano Furlani ${ }^{4}$, Veronica Rossi ${ }^{5}$, Carla Buosi ${ }^{6}$,

Alessio Rovere ${ }^{7}$ and Sandro De Muro ${ }^{6}$

${ }^{1}$ Dipartimento di Scienze Della Terra, Università di Pisa, Via S. Maria, 53, 56126, Pisa, Italy

${ }^{2}$ CEREGE Aix Marseille University, CNRS UMR 7330, IRD, Collège de France, INRAE. Europôle de l'Arbois BP 80 13545 Aix-en-Provence CEDEX 04, France.

${ }^{3} \mathrm{NIOZ}$ - Royal Netherlands Institute for Sea Research, Coastal Systems (TX), and Utrecht University, P.O. Box 59, 1790 AB, Den Burg, Texel, The Netherlands

${ }^{4}$ Dipartimento di Matematica e Geoscienze, University of Trieste, Italy

${ }^{5}$ Dipartimento di Scienze Biologiche, Geologiche e Ambientali, Universitì di Bologna, Via Zamboni 6740126 , Bologna, Italy.

${ }^{6}$ Dipartimento di Scienze Chimiche e Geologiche, Coastal and Marine Geoı ^rr iology Group (CMGG), Università degli Studi di Cagliari, 09042 Cagh ri, I ıly

${ }^{7}$ University of Bremen, Marum, ZMT, D-283,? Bremen, Germany

\section{Abstract}

We produced a new suite of sea-level data which allov $-i$ assessing the Holocene evolution of the Bonifacio Strait, a key coastal sector of the Mediterranear Se. which experienced significant morphological changes since the Last Glacial Maximum. Squeezed betwe $n$ Corsica and Sardinia islands, this strait connects the two major basins of the western Mediterranean $\mathrm{L} \cdot \mathrm{e}$ to its peculiar geographic and morphological setting, the Bonifacio Strait is affected by extrem f nelumarine conditions characterized by severe winds, waves, and currents.

The millennial sea-level changes ve e reconstructed through multiproxy investigations made of sediment coring and underwater beac'ru'sampling carried out on both sides of the strait. These data provided fresh insights into the timing of the progressive opening of the Bonifacio Strait which followed the Last Glacial Maximum when Corsica and Sardinia were connected forming the largest Mediterranean island. Major palaeogeographic changes occurred before $\sim 7 \mathrm{ka}$ BP. Since that period, the significant decrease of the northern ice-sheet melting triggered a significant sea-level stabilization which induced only minor modifications in the palaeogeography of the strait. In the late Holocene, the isostatic-related subsidence became the dominant factor controlling the sea-level changes which rose with rates $\leq 0.35 \mathrm{~mm} \mathrm{a}^{-1}$ in the last four millennia.

Our data have also an important archaeological implication because they indicate that the Bonifacio Strait has not represented a significant geographical barrier along the early Neolithic migration path which 
connected mainland Italy to northern Corsica and finally to Sardinia. This further confirms the ability of early Neolithic communities to navigate not also across large sea stretches but also maritime areas characterized by extremely complex meteomarine conditions.

\section{Introduction}

The Bonifacio Strait is a narrow coastal stretch connecting the two main basins of the western Mediterranean Sea and dividing the islands of Corsica and Sardinia, the third and the second largest western Mediterranean Islands. At the end of the Last Glacial Maximum (LGM, 20 ka), with sea level 120-140 m below present (e.g. Lambeck and Purcell, 2005), Corsica and Sardinia were connecte d. forming the largest Mediterranean island (with an area of about $47,000 \mathrm{~km}^{2}$ ) placed in the middle of the v esu $\mathrm{n}$ part of the basin (Lambeck and Purcell, 2005). The progressive melting of the northern hemisph re $k \geqslant$ sheets produced a very rapid sealevel rise until $\sim 7.0$ ka ago (e.g. Peltier, 2004; Lambeck $e^{ \pm}-1$., 2014) which resulted in the progressive development of the Bonifacio Strait and the separation of Cr.sic. and Sardinia. Conflicting sea-level data are presently available in the literature (Vacchi et al., $20^{1} 6,208$ ) resulting in uncertainties regarding the timing and magnitude of this major palaeogeographi ch nge. In particular, sea-level data from sediment cores performed in Sardinian coastal lagoons (Di ? ita and Melis, 2013; Melis et al., 2017; 2018) show a significant departure from a sea-level stand derived $\mathrm{rc}_{\mathrm{n}} \sim$ ome Neolithic archaeological data ( $7.3 \mathrm{ka}$ BP) found in a submerged cave in north-eastern Sardi.ं.? (Palombo et al., 2011; Benjamin et al., 2017).

This paper aims to provide novel : ola data on the Relative Sea Level (RSL) changes in this important Mediterranean sector, notably for he Holocene period (last $12.0 \mathrm{ka} \mathrm{BP}$ ). We thus produced a new geological sea-level dataset that was cou led with geophysical models and GIS analysis to provide new insights into the coastal landscape modifications triggered by the postglacial sea-level rise on both sides of the Bonifacio Strait.

There is further archaeological interest in better constrain the palaeogeographical evolution of the Bonifacio Strait since it always represented the most rapid way to cross from Sardinia to Corsica. Archaeological evidence of human frequentation was recovered along both sides of the strait and dated from the Mesolithic to the Roman Times (e.g., Modi et al., 2017; Lugliè et al., 2018; Revelles et al., 2019). This narrow strait always represented a key crossroad not only for the crossing from Corsica to Sardinia but also for naval trading routes across the Western Mediterranean, notably linking the Spanish colonies to Rome (e.g., Medas, 
2005; Opdebeeck, 2005; Reynolds, 2010). However, the extreme meteomarine conditions coupled with the complex geomorphology characterized by many emerging reefs have always made navigation in the strait very complex (e.g., Sorgente et al, 2012). This is not only testified by the number of historical shipwrecks found in the area (Opdebeeck, 2005; Boetto 2012; Secci et al., 2013) but also by a large number of presentday maritime incidents, that make the passage of ships with dangerous goods presently strongly discouraged and subject to mandatory piloting (Sorgente et al., 2012).

\section{Study area}

Sardinia $\left(\sim 24,100 \mathrm{~km}^{2}\right)$ and Corsica $\left(\sim 8,640 \mathrm{~km}^{2}\right)$ are the second and tie third-largest islands of the western Mediterranean (the largest being Sicily). The Bonifacio Strait (hereaf er Los) separates the two islands with $\sim 80,000$ ha of sea, and hosts a large number of small islands, is sts a nd sea shoals (De Muro et al., 2010; Buosi et al., 2012, Fig. 1A). The geology of both northern Sa nia and southern Corsica is dominated by the Hercynian batholiths of Upper Carboniferous-Permian age ha cterized by different calco-alkaline granitic formations and fields of basic dikes (Oggiano et a. $2^{\prime}$ 09). In northern Sardinia, the post-Hercynian formations are limited to Quaternary deposits $\mathrm{n}$ th 2 coastal areas and alluvial plains, except a very limited outcrop of Miocene limestone (Carmigna: et al, 2016). Miocene marine sedimentary rocks outcrop in southern Corsica for a total surface area ( $f, 5 \mathrm{~km}^{2}$, notably around the town of Bonifacio (Tommasetti and Brandano, 2013). The coastal geomrr $r_{Y}$ 'ology of both sides of the BoS is strongly related to the dominant granitic nature of the substrate (L. Muro et al., 2017) which resulted in several gently sloping rocky promontories alternated with rive, inlets often hosting brackish lagoons or salt-marshes. This peculiar riashape geomorphology is the re: ult of the postglacial drawings of former river valleys (Soldati and Marchetti, 2017). The sole exception to the general granitic landscape is represented by scenic steep cliffs of Bonifacio which are carved in the Miocene rocks (Tommasetti and Brandano, 2013; Furlani et al., 2014). The tidal regime is microtidal and does not exceed $\pm 0.2 \mathrm{~m}$ (De Falco et al., 2011).

The BoS separates two distinct Mediterranean sub-basins, the Tyrrhenian Sea and the Algero-Provençal (see Fig. 1B). The strait, $\sim 11 \mathrm{~km}$ wide between mainland Corsica and Sardinia, hosts two main archipelagos Lavezzi (Corsica) and La Maddalena (Sardinia) which are composed by 10 main islands and $\sim 75$ small islets. In the central portion of the strait, the maximal depth of the seafloor is reduced to $\sim-70 \mathrm{~m}$ while in the eastern 
and western openings of BoS depths slowly decreases down to 90-100 m before approaching the continental slope, where strong bathymetric gradients occur (Cucco et al., 2012; Gérigny et al., 2015).

Due to its morphology, the BoS presents a very peculiar meteomarine setting. Winds blow 328 days per year, with a wind speed exceeding $16 \mathrm{~m} / \mathrm{s}$ ( 31 knots) for over $52 \%$ of events (Cucco et al., 2012; Gérigny et al., 2015). This triggers high-intensity currents sometimes up to $1 \mathrm{~m} / \mathrm{s}$ (Gérigny et al., 2015). The main wind directions are the north-western Mistral and the south-western Libeccio, which are orographically controlled (De Falco et al., 2011). Western wind speed increases by up to $20 \%$ due to the Venturi tunneling effect caused by the funnel shape of the strait (Cucco et al., 2012). NW win is crossing the strait contribute to the generation of a wind-driven quasi-stable cyclonic gyre in the northe $\mathrm{n}$ ivrrhenian Sea that represents the most energetic mesoscale structure of this portion of western Mer iterr. nean (Iacono et al., 2013, Olita et al., 2015).

\section{Methods}

\subsection{Facies analysis and sea-level data from sedimen. :or es}

Sediment cores carried out in transitional envir 'nm' nts represent one of the major sources of Holocene sealevel data along the global coastlines (e.g., I han et al., 2019). In this paper, we used sea-level data derived from six cores that were recently drilled i $\mathrm{T}$ ia . arella (southern Corsica) and Budelli (a small island placed in La Maddalena archipelago, $\sim 8 \mathrm{~km} \mathrm{u}_{i}{ }^{\mp}$ the northern Sardinian coast) (Fig. 1C). Coring activity was carried out using a Cobra vibracorer with a :varaulic extraction system. All vertical measurements were undertaken using a DGPS (Differential jeos aphical Positioning System) and referred to the French geodetic datum (NGF) which is $0.12 \mathrm{~m}$ below he present mean sea level (msl, Morhange et al., 2013; Vacchi et al., 2016). The final vertical error associated with the coring activity is $\pm 0.05 \mathrm{~m}$.

Besides the visual inspection of the cores, the reconstruction of the depositional environments was performed coupling grain size analysis with the quantitative determination of the faunal assemblages (i.e. molluscs and ostracods) found along the cored succession (e.g., Amorosi et al., 2014; Curras et al., 2016; Chelli et al., 2017).

For grain-size determinations, samples were taken at $5 \mathrm{~cm}$ intervals. Many displayed fine particles, with a general size below $200 \mu \mathrm{m}$ (e.g., Ghilardi et al., 2017). Organic matter was removed for laser-diffraction particle size study. The grain-size distribution was measured using a Beckman Coulter LS 13320 laser 
granulometer with a range of 0.04 to $2000 \mu \mathrm{m}$, in 132 fractions. The calculation model (software version 5.01) uses Fraunhöfer and Mie theory. For the calculation model, we used water as the medium (RI $=1.33$ at $20^{\circ} \mathrm{C}$ ), a refractive index in the range of that of kaolinite for the solid phase (RI $=1.56$ ), and absorption coefficients of 0.15 for the 780-nm laser wavelength and 0.2 for the polarized wavelengths (Buurman et al., 1996). Samples containing fine particles were diluted, measuring between 8 and $12 \%$ of obscuration and between 45 and 70\% PIDS (Polarization Intensity Differential Scattering) obscuration. For what concerns the mollusc fauna, all samples were wet-sieved through a $300 \mu \mathrm{m}$ wire mesh screen and air-dried at room temperature. The portion greater than $300 \mu \mathrm{m}$ were examined un ler a binocular microscope and all identifiable shells and fragments were collected and analyzed in epa ate plastic tubes (see details in Revelles et al., 2019). Identification of molluscan shells was subse ruen ly assigned to assemblages according to the Péres and Picard (1964) and Péres (1982) classific...nn system. In Piantarella lagoon, additional ostracod analyses, performed on 28 samples collected from $t^{1}$ ie 1 , ference core P1 and reported in Revelles et al. (2019), were used to support refine the pale nv ronmental interpretation and the changes in depositional environments along the studied sur ces' ions (Marriner et al., 2012; Giaime et al., 2017; Rossi et al., 2017).

The results of the palaeoenvironmental er o siructions (see results section) revealed depositional facies associations typical for coastal lagoons, hrackish swamps, and shallow-marine environments. All these facies can provide very useful insights in ' the sea-level evolution, notably in the Mediterranean context (e.g., Marco-Barba et al., 2013; F nntaı a et al., 2017; Brisset et al., 2018). Among them, lagoons and brackish swamps were widely used to 1 oduce relative Sea-Level Index Points (SLIP i.e. a point that constrains the palaeo RSL in time and space; e.g. Shennan et al., 2015) in Mediterranean sea-level studies (e.g., Fontana et al., 2017; Melis et al., 2017; 2018; Chelli et al., 2017; Brisset et al., 2018).

Following the protocol developed by Vacchi et al. $(2016,2018)$, we attributed the following indicative range (i.e. the relationship of the dated facies association with the contemporary msl) to the dated samples:

i) 0 to $-1 \mathrm{~m} \mathrm{msl}$ to samples collected from semi-enclosed/low-marine influenced lagoon deposits, characterized by the dominance of brackish-water molluscs and the euryhaline ostracod Cyprideis torosa, (Rossi et al., 2011; Salel et al., 2016; Chelli et al., 2017); 
ii) 0 to $-2 \mathrm{~m} \mathrm{msl}$ to samples formed under open/high-marine influenced lagoon conditions, with a high species diversity of the faunal assemblages comprising marine and brackish molluscs, and a meiofauna dominated by brackish-marine species (Rossi et al., 2011; Marriner et al., 2014; Salel et al., 2016); iii) $\pm 0.5 \mathrm{~m}$ msl to samples from brackish swamp facies where macrofaunal and ostracod assemblages dominated by freshwater to slightly brackish taxa (e.g., Marriner et al, 2012; Giaime et al., 2017).

Mediterranean shallow marine facies associations (i.e. foreshore, shoreface) are generally characterized by fine to coarse sands deposited in the first few meters below msl. Mollusc and meiofauna assemblages mainly include infralittoral species (Amorosi et al., 2017) and abundant Posidonıa reanica beds, a marine seagrass living down to $40 \mathrm{~m}$ depth (e.g., Montefalcone et al, 2016). Due to th $\mathcal{\cdot}$ difficulty in establishing a direct relationship with the former msl, we used samples depositec wlum shallow-marine settings to produce Marine Limiting Points (MLP, i.e. a point that constrains the 'SL above an elevation, Shennan et al., 2015).

\subsection{Petrographic analysis and sea-level data from b a hrock samples}

Beachrocks are cemented coastal deposits that $r_{-}$'e f $_{\text {ten }}$ been used to assess Holocene shoreline migration and sea-level changes, notably in the Mediterran 'n Sea (e.g., Desruelles et al., 2009; Mauz et al., 2015; Karkani et al., 2017). The use of beachroc $\sim$ as recise RSL indicators strongly dependent on the analysis of cement mineralogy and, if possible, of l'e' 'titry morphology of a beachrock outcrop (e.g., Vacchi et al., 2012; Mauz et al., 2015). These analyses " "low identifying the spatial relationship between the past shoreline and beachrock formation zone and thw he definition of the indicative meaning of the sample (Mauz et al., 2015). Along both sides or Bur, a significant number of beachrocks were studied since the ' 80 s (e.g., Nesteroff, 1984; Ozer et al, 1984; De Muro and Orrù, 1998). Their depths range from few cms below the present msl to -70 m (De Muro, 1990) and their ages span the whole Holocene (Nesteroff., 1984; De Muro and Orrù, 1998). However, recent investigations (Vacchi et al., 2017, 2018) highlighted some significant problems in the ages yielded by some bulk cement samples collected in the BoS, notably in the samples younger than $7.0 \mathrm{ka} \mathrm{BP}$. This is particularly evident for the samples collected by Nesteroff (1984) which were likely rejuvenated by multiple cementation processes in the shallow water after the Mid Holocene RSL stabilization (e.g., last $~ 7.5 \mathrm{ka}$ BP, Vacchi et al., 2017).

For this reason, we carried out a new beachrock sampling campaign in Cala Lunga (Corsica, Fig. 1C) and Tanca Manna (Sardinia, Fig. 1C). Underwater surveys were carried out to record beachrocks features (depth 
below msl, width and, if present, sediment bedding and structure) and to sample the beachrock slabs (Vacchi et al., 2012; Mauz et al., 2015; Karkani et al., 2017). Depth of the samples was recorded by averaging 2 electronic depth gauges, with an accuracy $\pm 0.5 \mathrm{~m}$ (Rovere et al., 2010; Vacchi et al., 2012). Thin sections were cut to perform petrographic (polarizing microscope) and microstratigraphic analyses. These observations allowed the characterization of the constituents, the presence of bioclasts as well as the type of cement. These analyses are required to produce considered precise RSL index points from beachrock samples (e.g., Desruelles et al., 2009; Mauz et al., 2015). In the intertidal zone, the metastable aragonite and High Magnesium Calcite (HMC) form as irregularly distributed nee lles, isopachous fibers or rims, and micritic cement (Desruelles et al., 2009). Samples having these ch rac eristics have an indicative range encompassing the whole tidal range (mean high water to mean lor'wa er), thus $\pm 0.20 \mathrm{~m}$ (Porto Torres Tidal Station, www.mareografico.it).

\subsection{Chrono-stratigraphy}

The age of the samples was established by a series $\mathrm{r} \leq \mathrm{w} 19 \mathrm{AMS}{ }^{14} \mathrm{C}$ radiocarbon dates taken from marine/lagoonal shell, organic sediments as we as from remains of the Mediterranean seagrass Posidonia oceanica (Table 1). Because the productio. of atmospheric radiocarbon has varied through geological time, radiocarbon ages were calibrated to pro id ¿ ates in sidereal years with a $2 \sigma$ range. All samples were calibrated using CALIB 7.0. We user - laboratory multiplier of 1 with $95 \%$ confidence limits and employed the IntCal13 and Marine13 (Reimc et al., 2013) datasets for terrestrial samples and marine samples (averaged $\Delta \mathrm{R}$ for the region is $27 \pm 32$, Reimer et al., 2004), respectively.

\subsection{Relative Sea-Level and pc laeogeographic reconstructions}

For each dated sample, SLIPs were produced using the following equation:

$\operatorname{SLIP}_{\mathrm{i}}=\mathrm{A}_{\mathrm{i}}-\mathrm{I}_{\mathrm{i}}$

(Shennan and Horton, 2002; Shennan et al., 2015), where $A_{i}$ is the altitude and $I_{i}$ is the midpoint of the indicative range (the reference water level) of sample i, both expressed relative to the same datum, msl in our analysis.

The total vertical error is obtained by adding in quadrature individual errors according to Shennan and Horton, (2002). These errors represent the sources of error for each SLIPs including the indicative range. 
MLPs are also subjected to these errors, except for the indicative range which does not apply for these kinds of sea-level data (Hijma et al., 2015; Khan et al., 2019).

We used the newly assembled RSL record to attempt the reconstruction of the Holocene palaeo-coastline evolution of BoS based on the high-resolution modern bathymetry (EMODnet Bathymetry Consortium, Thierry et al., 2019). The bathymetric data were imported and processed in a GIS environment (QGIS 3.10 software). We remark that caution should be adopted in such kind of palaeogeographical reconstructions, especially in those sites that were most likely affected by major progradation processes. However, this is not the case of the BoS which is mostly characterized by rocky coastli ies and coastal plains with a limited extent.

\subsection{Predictions of Relative Sea-Level}

We compared the newly assembled suite of SLIPs and MLP, 'VL'? four different geophysical Glacio-hydro isostatic adjustment (GIA) models which predict the RSL er olu nn in this portion of the Mediterranean Sea. Geological data are strongly needed to both constrain 'es: models and to test the accuracy of predictions made using them (e.g., Stocchi and Spada, 20 /; I imbeck et al., 2011; Peltier et al., 2015). In particular, by comparing RSL data to GIA predictions in he Mediterranean Sea, it is possible to infer parameters relating to the rate and geographic source of me wat... influx (e.g. Stocchi et al., 2005; 2018; Vacchi et al., 2018) and the rheological structure of the soi. ${ }^{~}$ Earth (e.g. Stocchi and Spada, 2009; Lambeck et al., 2011; Roy and Peltier, 2018).

We obtained the RSL model rea tions for the BoS by solving the Sea Level Equation (SLE) according to the pseudo-spectral method (S\} ada and Stocchi, 2007). We compared three different ice-sheet chronologies that describe the melting of the Last Glacial Maximum ice-sheets up to the present: ICE-5G (Peltier, 2004), ICE-6G (Peltier et al., 2015) and ANICE-SELEN (De Boer et al., 2014). The SLE was solved for a spherical, self-gravitating, rotating, and deformable Earth model that is characterized by a $100 \mathrm{~km}$ thick elastic lithosphere, a three-layer Maxwell viscoelastic mantle, and an inviscid core. Each of the three computations allowed to predict a nominal RSL curve, based on a three-layer approximation of the multi-layered viscosity profile VM2 characterized by upper mantle and transition zone viscosity of $0.5 \times 10^{21} \mathrm{~Pa}$ s and lower mantle viscosity of $5 \times 10^{21} \mathrm{~Pa}$ s (Peltier, 2004; Stocchi et al., 2018). We further compared our data with the RSL prediction for the BoS released by Lambeck et al., (2011) using the K33_j1b_WS9_6 geophysical model 
(hereafter K33). The rheological parameters adopted for this computation correspond to the three-layer model with an effective elastic lithospheric thickness of $65 \mathrm{~km}$, an upper mantle viscosity of $3 \times 10^{20} \mathrm{~Pa} \mathrm{~s}$ and a lower mantle viscosity of $3 \times 10^{22} \mathrm{~Pa}$ s (Lambeck et al., 2011).

\section{Results}

\subsection{Depositional facies of Piantarella and Budelli cores}

Piantarella cores reached the maximal depth of $\sim 6.5$ below the surface. They were performed on the border of the lagoon at elevations ranging from 0.24 to $0.07 \mathrm{~m}$ above the msl (Fig. 2A). In Piantarella 1, the core reached the granitic substrate. In Budelli, the cores did not exceed $1 \mathrm{~m}$ 'elow the surface and all reached the granitic basement. They were performed in a brackish swamp derelo ing in a backshore depression at elevations ranging from -0.25 to $-0.5 \mathrm{~m}$ msl.

The multiproxy analysis of sedimentology and faunal assemr... res revealed facies typical of Mediterranean coastal lagoons (Unit L1 and L2), washover fan (W), brack h swamp (Unit BS), and shallow marine environments (Unit M1 and M2). The detailed $\operatorname{des}^{\sim} \mathrm{r}_{1}^{-}$. 1 r of the grain sizes and faunal assemblages of Budelli cores is provided in Appendix 1, while 'los for the Piantarella cores are reported in Revelles et al., (2019).

\section{Brackish swamp facies (Unit BS)}

This depositional facies was found bnt. in the uppermost part of Piantarella and in Budelli cores. Unit BS is made of greyish silty clays with $n_{\mathfrak{k}}$ - derate organic matter content (up to $\sim 30 \%$ ). Macrofaunal shells are absent, while ostracods are $\arg$ ly represented by Cyprideis torosa (ca. 77\%) an opportunistic, truly euryhaline species able to th ive from almost freshwater to hypersaline conditions irrespective of the substratum features (Athersuch et al., 1989; Meisch, 2000). C. torosa is accompanied by remarkable percentages of freshwater - low brackish taxa as Heterocypris salina (ca. 17\%; Henderson, 1990) and very low percentages of brackish and euhaline taxa (e.g. Loxoconcha species and Aurila arborescens <2\%). Sporadic evidence of Posidonia oceanica layers was also observed in Budelli. This unit corresponds to the modern brackish swamp environment that can be observed both in Piantarella and in Budelli. The age of BS facies ranges from $\sim 3.4$ to $\sim 0.3 \mathrm{ka} \mathrm{BP}$ in Budelli and from $\sim 0.8$ to $\sim 0.3 \mathrm{ka} \mathrm{BP}$ in Piantarella (Table 1). 
Unit L1 is made of dark clays characterized by organic matter percentages that do not exceed $18 \%$. Abundant plant remains and large wood fragments were found embedded within the organic clays. The macrofaunal assemblages show a very low diversity being dominated by the lagoonal bivalve Cerastoderma glaucum often found in living position (articulated valves). No ostracod information was available. However, the very low diversity of species and the sedimentology of this layer are consistent with a semi-enclosed lagoon environment. This facies develops from $\sim 6.7$ to $\sim 5.5 \mathrm{ka} \mathrm{BP}$ at the bottom of P3 core while it was dated at 4.6 ka BP in P2 core (Fig. 2, Table 1).

Unit L2 is characterized by coarse sands alternated with clay, which c ntain intact specimens of marine and lagoonal molluscs such as Loripes lacteus, Cerithium sp., Bittium ret ¿um 'um and C. glaucum. Presence of $P$. oceanica layers was also observed. The ostracod fauna is don nate 1 by the euryhaline species $C$. torosa (ranging between ca. 65-85\%), mainly accompanied by $\mathrm{b}^{r}$ - $\mathrm{k}_{1 \mathrm{~s}}$ ? and brackish-euhaline taxa preferring vegetated substrates as Loxoconcha elliptica (ca. 2-8.5\%), Loxoconcha stellifera (ca. 6-13\%) and Xestoleberis communis $(<5 \%)$. Low percentages of c 'st l-shallow marine species as Loxoconcha gr. $L$. exagona $(<7 \%)$ and Aurila arborescens $(<5 \%$ ) al o occur. Sedimentological features and the highly diverse fossil content, characterized by a mixed bra. kish-shallow marine fauna, indicate that this unit was formed in an open lagoonal environment with signif a at . narine influence. This facies association was only found in P1 core and its upper part was dated $₫ x-4.3 \mathrm{ka} \mathrm{BP}$ (Fig. 2).

Marine facies (Unit M1 and M2)

Unit M1 is made of grey fin sa ds mixed with clays and rich in P. oceanica remains. The macrofaunal assemblage is dominated by la ge specimens of C. glaucum. The ostracod fauna is mainly represented by epiphytic taxa able to tolerate a wide range of salinity conditions as L. elliptica (ca. 17-41\%), L. stellifera (ca. 13-19.5\%) and Xestoleberis species (ca. 13-39\%), with the remarkable occurrence (ca. 20-32\%) of shallow marine-coastal species (as A. arborescens, Loxoconcha gr. L. exagona and Palmoconcha turbida). Interestingly, the euryhaline species $C$. torosa occurs although with low percentages (ca. 2.5-11.5\%). Both sedimentology and the faunal assemblages of this unit are consistent with a semi-protected environment characterized by a dense seagrass cover at the bottom and salinity conditions oscillating around the marine values as a coastal bay/embayment. This facies was found at the bottom of core P1 ( 7.4 to $\sim .1 \mathrm{ka}$ BP) and in the mid-upper part of core P3 (no dates, Fig. 2). 
The M2 Unit is characterized by fine to coarse grey sands with the abundant presence of P. oceanica. It was found both in Piantarella (P1 and P2) and in all the Budelli cores. The macrofaunal assemblages are dominated by the infralittoral gastropods B. reticulatum, Rissoa ventricosa, Nassarius reticulatus and by shallow marine to lagoonal bivalve species mainly represented by C. glaucum and L. lacteus. In Budelli, the bivalve species were mainly characterized by $R$. ventricosa, B. reticulatum and Abra sp. In Piantarella, this Unit also contains few valves of poorly-preserved brackish and brackish-euhaline ostracods at places accompanied by an autochthonous fauna with dominant shallow marine-coastal species (>55\%) as Loxoconcha gr. L. exagona, A. arborescens, Pontocythere turbic a and Palmoconcha turbida. The sedimentology and the faunal assemblages suggest Unit M2 de Josı ad in a foreshore to shoreface environment that was less protected and likely less embayed than t ie $\mathrm{N}, 1$ one. This is further corroborated by the presence of in-situ fossil matte of P. oceanica at the bottr... on the B1 core, which is a clear indication of a marine environment at $\sim 2.7 \mathrm{ka} \mathrm{BP}$. This unit was also four $1 \mathrm{a}$ the bottom of B2 core $(\sim 3.7 \mathrm{ka} \mathrm{BP})$ and the bottom of P2 core ( 4.6 ka BP, Fig. 2). No dating w a a ailable for the M2 Unit occurring in P1 and B3 cores.

Beach barrier/washover fan deposit (W)

This Unit is characterized by medium to c a st sand layers with remains of P. oceanica. It was observed in P1 core and in B1 and B2 cores (Fig. ?) where sands show evidence of oxidation. Shells are always very fragmented and hard to recognize, $w$ ' iile ostracods are absent. The interpretation of the depositional facies of this Unit is very complex, hr wev $r$, the sedimentological features and the stratigraphic position suggest a high-energy, coastal environme it subject to overwash processes such as a washover fan. Due to the lack of datable materials, no ages are available for this Unit both in Piantarella and Budelli.

4.2. Beachrocks morphology and microstratigraphy

Underwater surveys performed in Tanca Manna (Sardinia) and Cala Lunga (Corsica) revealed the presence of multiple beachrock outcrops occurring nearly parallel to the present coastlines (Fig. 3A,B). In Tanca Manna (Fig. 3A), a shallow beachrock develops from -0.8 to $\sim 1.2 \mathrm{~m}$ msl (Fig. 3C) while a deeper outcrop occurs between -3.5 m and -3.9 m msl (Fig. 3D). In Cala Lunga (Fig. 3B), a shallower beachrock develops from -0.3 to $-0.6 \mathrm{~m} \mathrm{msl}$ (Fig. 3E) while the deeper one was found between -3.4 and $-3.8 \mathrm{~m} \mathrm{msl}$ (Fig. 3F). Microscope observations indicated grain sizes ranging from fine to medium sands even if internal sediments 
of smaller size were observed between grains (Fig. 3G). We further observed the presence of bioclasts, often showing a very high degree of preservation notably in the deepest outcrops of Tanca Manna (Fig. 3H) and in Cala Lunga (Fig. 3K). The bounding materials observed between grains and bioclasts are mainly characterized by early intertidal and poloidal cements. The observed early intertidal cements were characterized by small bladed isopachous fringe of limpid and contiguous HMC crystals (Fig. 3G,H) or characterized by micritic texture (irregularly shaped and of microbial origin) followed by radial fibrous HMC calcite (Fig. 3J). Peloidal cements are made of micrite partially replaced by coalescent pellet clusters. These pellets are agglomerates of particles that could form during the dagenesis inside the pore space within the intertidal zone (Fig. 3J,K).

Microscope analysis identified that cement thickness is always les; tha $150 \mu \mathrm{m}$. As a result, their extraction for radiocarbon dating was extremely difficult. Moreov lie presence of micritic fillings, often recrystallized, could affect the radiocarbon dating produc;.ıg inparently older dates. However, the high degree of conservation of the bioclasts in the beachrork if $r$ th Tanca Manna and Cala Lunga, allowed us to attempt two radiometric datings on Tellinidae a ad $\mathrm{r}$. onidae shells. We selected two samples that most likely

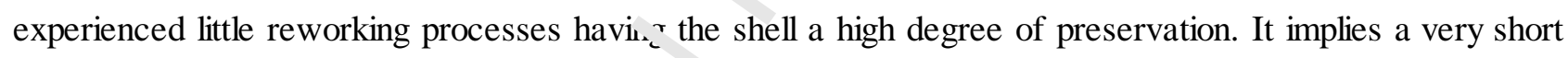
permanence of the dead bioclast on the e $^{\prime} \mathrm{c}_{\mathrm{l}}$, before the fossilization within the beachrock formation. For this reason, we assumed that the biork t age can reasonably correspond to the age of the whole beachrock

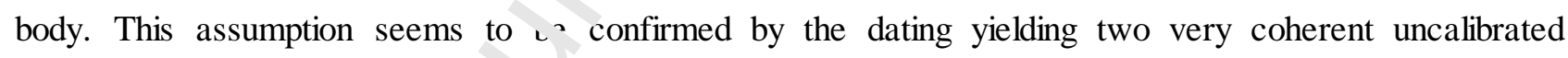
radiocarbon ages of $6050 \pm 3(\mathrm{BP}$ ind $5920 \pm 30 \mathrm{BP}$ (Table 1, Fig. 3A,B).

\subsection{RSL reconstructions}

Our new radiocarbon dataset provides novel insights on the RSL evolution in the BoS (Fig. 4). We produced a new suite of SLIPs (11 from the cores and 2 beachrocks), and 6 MLPs (Table 1). These data were coupled with the other beachrocks (2 SLIPs) and sedimentary data (2 SLIPs and 2 MLPs) already available for the BoS (Table 2). The oldest data (beachrocks) indicate that RSL rose from $29.5 \pm 1.6 \mathrm{~m}$ at $\sim 9.8 \mathrm{ka}$ BP to 17.5 $\pm 1.6 \mathrm{~m}$ at $\sim 8.8 \mathrm{ka}$ BP. Younger MLP document the progressive rise of RSL that was at or slightly above -6.0 and $-4.9 \mathrm{~m}$ msl at $\sim 7.4$ and $\sim 7.2 \mathrm{ka}$ BP respectively.

Between $\sim 6.4$ to $\sim 6.3 \mathrm{ka} \mathrm{BP}$, the beachrocks of Tanca Manna and Cala Lunga beachrocks place the RSL between $-3.8 \pm 0.5$ and $3.7 \pm 0.5 \mathrm{~m}$ msl, respectively. This is in very good agreement with the SLIPs derived 
from Piantarella cores which document a RSL from $-3.3 \pm 0.6 \mathrm{~m}$ msl at $\sim 6.6 \mathrm{ka}$ BP to $-3.0 \pm 0.6 \mathrm{~m}$ at $\sim 6.3$ ka BP and subsequently to $-2.1 \pm 0.5$ at $\sim 5.5 \mathrm{ka}$. Between $\sim 4.6$ and $\sim 4.3 \mathrm{ka} \mathrm{BP}$ a composite RSL made of two MLPs and three SLIPs indicate RSL was likely placed between -1.2 and $-1.6 \mathrm{~m}$ msl in good agreement with the coeval MLPs. RSL rose to $-0.8 \pm 1.0$ at $\sim 3.6 \mathrm{ka}$ BP while SLIPs indicate that the total RSL variation did not exceed $1.1 \mathrm{~m} \mathrm{msl}$ in the last $2.4 \mathrm{ka} \mathrm{BP}$.

\section{Discussion}

\subsection{Drivers of RSL changes in the Bonifacio Strait}

The interplay between eustatic, GIA and tectonic components largely c ontrolled the variability of postglacial RSL changes along the global coasts (e.g., Khan et al., 2015). In the Mec iterranean Sea, crustal movements triggered by Holocene activity of major faults and/or volcanic acti ity , ften significantly influenced the RSL evolution (e.g., Pirazzoli, 2005; Morhange et al., 2006; Vacc'‥ st .1., 2019). This has often complicated the identification of the GIA component in the RSL record, whir't ce nstitutes an important driver of past, present and future sea-level variability (e.g. Milne et al., 20ns, Kran et al., 2015, 2019). This issue is even more complex in those coastal regions located at the mo th or major Mediterranean rivers, for instance the Ebro, (Somoza et al., 1998), the Nile (Marriner eı ^l., 201'2) or the Po (Bruno et al., 2020), where the RSL records were strongly affected by long-term subs $d f \mathrm{n} \sim$ ( (with rates up to $\sim 3 \mathrm{~mm} \mathrm{a}^{-1}$ ) induced by sediment loading and compaction.

In this context, the newly producec Holocene RSL geological record in the BoS is of particular interest because:

i) the Sardinia-Corsic $\downarrow$ block is considered one of the most tectonically stable Mediterranean areas (e.g., Nocquet, 2012; Faccenna et al., 2014)

ii) most of the sedimentary datapoints were made of basal samples (i.e., samples recovered from sedimentary units overlying incompressible substrates, rocky basements, or a thick layer of coarse sand or gravel) and are therefore less prone to compaction (Hijma et al., 2015). Also, beachrock samples are considered virtually incompressible samples (Mauz et al., 2015).

The RSL record extends the last $\sim 10.0 \mathrm{ka}$ and is particularly robust in the last $6.5 \mathrm{ka} \mathrm{BP}$. In the Early Holocene period, the two beachrock samples indicate RSL rose with rates of $12.6 \pm 3.3 \mathrm{~mm} \mathrm{a}^{-1}$ between $\sim 9.8$ and $\sim 8.8$ ka BP. These rates, mainly controlled by the eustatic deglacial signal, are consistent (within error 
bars) with the near-uniform global sea-level rise at average rates of $\sim 15 \mathrm{~mm} \mathrm{a}^{-1}$ between $\sim 11$ and $\sim 8.2 \mathrm{ka}$ BP (Lambeck et al., 2014). Between $\sim 8.2$ and $\sim 6.7 \mathrm{ka} \mathrm{BP}$, the final phase of North American deglaciation (Peltier, 2004; Lambeck et al., 2014) and the consequent reduction of the meltwater input resulted in a significant deceleration of the global sea-level rise (Peltier, 2004). This is recorded by the BoS RSL record which shows a very sudden slow after $\sim 7.4 \mathrm{ka}$ BP. Since that period, the entire RSL variation did not exceed -6.1 m msl, in agreement with the data reported both in other coastal plains in Sardinia (Di Rita and Melis, 2013; Melis et al., 2017; 2018) and in southern Tuscany (mainland Italy, facing southern Corsica, D’Orefice et al., 2020). On the contrary, this RSL evolution pattern conflicts w ith the archaeological data from the submerged portion of the Grotta Verde cave (northwestern Sar ını Benjamin et al., 2017) whose exploration dates back to the 1970s (Lo Schiavo 1987; Guillo 19.1). Here, evidence of pottery from Cardial period ( 7.3 ka BP) found at $\sim-10 \mathrm{~m} \mathrm{msl}$ was used to ${ } \ldots$. $\mathrm{m}_{\llcorner}$truct a RSL placed at $\sim 11 \mathrm{~m}$ (Palombo et al., 2017; Benjamin et al., 2017), that is 4 to $5 \mathrm{~m}$ below t'e c veval RSL position derived from the cores performed in the surrounding coastal plains (see $\operatorname{Vac} k_{i}$ it .1., 2018 for a detailed discussion of these data). Guillot (1997) reported considerable debris flo $/$ al ng the flank of the cave and several ceramic fragments were found mixed within this debris down $九 \sim-22 \mathrm{~m}$. This may be an explanation for this misfit but only by new high-resolution mapping of the subme $\mathrm{g} \cdot \mathrm{\lrcorner}$ - ave and/or by new sediment cores that should be performed in the coastal plains adjacent to the cav would provide robust evidence to solve this intriguing issue.

Of particular interest is the RSL ev'lution since $7.0 \mathrm{ka}$. In this period, a global progressive decrease in the rising rates was documented (Pe ier, 2004; Lambeck et al., 2014) with the GIA-related deformation that becomes the main factor contrc ling the RSL changes.

In the Mediterranean, the predicted GIA-driven land-level changes are controlled by the interplay between ice and water loading. The former is directly influenced by the spatiotemporal variations of shape and size of the nearest ice sheets (Eurasia but also North America) and, accordingly, by the upper portion of the Earth's mantle. The latter mostly depends on the volumetric variation of the ice sheets (glacioeustatic water loading) and, because of the size of the Mediterranean basin, on the lower portion of the mantle (Lambeck and Purcell, 2005; Stocchi and Spada, 2009). Overall, the effects of the nearest ice sheet (Fennoscandia) tend to be dependent on the latitude, while those of the North American ice sheets have a longitudinal pattern across the Mediterranean basin (Lambeck and Purcell, 2005; Stocchi and Spada, 2009; Stocchi and Spada, 2005). 
Instead, the water loading term results in widespread subsidence that reach the maximum in the bulk of basin (Lambeck and Purcell, 2005; Stocchi and Spada, 2009; Roy and Peltier, 2018) and that is also compensated by uplift along the continental margins (Stocchi et al., 2018).

The new dataset provides insights into the magnitude of this contribution in the center of the western Mediterranean basin. In particular, the presence of coeval samples of beachrocks and lagoonal samples at $\sim 6.5 \mathrm{ka}$ BP robustly indicated that the maximal RSL variation was $\sim 3.5 \mathrm{~m}$. This implies average rising rates by $\sim 0.5 \mathrm{~mm} \mathrm{a}^{-1}$ in a period where the RSL variation is majorly controlled by the isostatic contribution. A further refinement of the magnitude of the GIA signal is provided by he Late Holocene record where the eustatic contribution is negligible due to the absence of global ice me ${ }^{1}$ sit ' $\mathrm{e}^{-4.0} \mathrm{ka}$ (Peltier, 2004; Milne et al., 2005; Engelhart et al., 2015). Our dataset indicates that the m ixim 1 GIA-related subsidence in the BoS did not exceed $0.35 \mathrm{~mm} \mathrm{a}^{-1}$. This value is of particular intere he ause GIA still contributes significantly to both modern and future sea-level change. Vacchi et al. (2018) i ighlighted the lack of Late Holocene robust data to quantify the GIA-related vertical motions, nctán in northern Sardinia. The improved dataset from the BoS represents thus a significant advance nen in the definition of the components which concur to the on-going RSL rise in this sector of the Med ${ }_{1}$ ?rranean basin.

\subsection{Implications for GIA modeling in th 1 e. .ern Mediterranean}

The newly assembled record constitutc a crucial benchmark to evaluate the predictive potential of a variety of GIA models in the western Meriterranean Sea. As stated in section 5.1, in the BoS record the RSL evolution is minimally influen :ed yy tectonics and compaction related subsidence. Furthermore, southern Corsica and northern Sardinia soasts lie in the center of the western Mediterranean basin, where all GIA models predict a maximum hydro-isostatic contribution (e.g., Lambeck and Purcell, 2005; Stocchi and Spada, 2009; Roy and Peltier, 2018).

The comparison between the new RSL dataset and the four geophysical predictions shows variability in the fit/misfit pattern along the Holocene period. In the Early Holocene (8.0 to $12.0 \mathrm{ka} \mathrm{BP}$ ), we observed a general misfit between models and data. The RSL position is significantly overestimated by ICE-5G, ICE6G, and ANICE models. This overestimation is larger than $\sim 5 \mathrm{~m}$ at $\sim 8.8 \mathrm{ka}$ BP and larger than $\sim 7 \mathrm{~m}$ at $\sim 9.8$ ka BP. Conversely, K33 significantly underestimates RSL: the predicted RSL is $\sim 15 \mathrm{~m}$ below the SLIP at $\sim 9.8 \mathrm{ka}$ BP and $\sim 10 \mathrm{~m}$ below the SLIP at $\sim 8.8 \mathrm{ka} \mathrm{BP}$. In the Mid to Late Holocene period (last $\sim 8.0 \mathrm{ka} \mathrm{BP}$ ) 
our dataset is based on a robust number of SLIPs (14) corroborated by 7 additional MLPs (Table 1 and 2). These data indicate that RSL was already at or above -6 $\mathrm{m}$ at $\sim 7.4 \mathrm{ka} \mathrm{BP}$, showing discrepancy with the coeval predictions of ICE-5G, ANICE, and K33 which underestimate the RSL position (Fig. 4). This underestimation is within $\sim 0.5$ and $\sim 1 \mathrm{~m}$ for ANICE and ICE-5G, respectively while the misfit increases up to $\sim 5 \mathrm{~m}$ for K33. Conversely, the ICE-6G model is in good agreement with the data for the entire Mid Holocene period.

The misfit between SLIPs and models decreases in the remaining part of the Holocene. In fact, we observed a good fit of ICE-5G, ICE-6G, and ANICE for the entire Late Holoce e period ( 4 to 0 ka BP) while K33 can reconcile the data only in the last $\sim 1.3 \mathrm{ka}$ (Fig. 4).

The expanded dataset from the BoS confirms the good prediction sote tial of ICE-6G model for the western Mediterranean area, at least in the Mid to Late Holocene pe (Gig. 4). Conversely, for ICE-5G, ANICE and K33 we observed a variable overestimation of the hyd o-L static component which become the major driver of RSL changes after the significant decrease of " elt water-equivalent input after $\sim 7 \mathrm{ka}$ BP (Lambeck et al., 2014).

The matter is different if we consider the Early Holocene record (Fig. 4). In this timespan, none of the models can reconcile the RSL evolution, $\mathrm{s}$ at -ady noticed in other portions of the western Mediterranean Sea (Brisset et al., 2018; Melis et al. ¿118; Vacchi et al., 2018). We speculate that this might depend on the ice-sheets models (shapes and sizes, as well as on the solid Earth parameters and stratification. However, further data are required to ( orro orate the Early Holocene record that is presently only composed by two beachrocks sampled and dated nore than 20 years ago (Nesteroff, 1984; Demuro and Orrù, 1998).

However, we remind that all the GIA models currently employed to predict RSL in the Mediterranean Sea do not consider the lateral variations in mantle viscosity or the thickness of the lithosphere (Melini and Spada, 2019). This represents a limitation because it is known that these parameters may significantly affect the Earth's response to deglaciation (Spada et al., 2006).

5.3. Palaeogeographic evolution of the Bonifacio Strait and influence on the early colonization of the Islands The palaeogeographic reconstructions of the former shorelines have a great geoarchaeological interest because coasts have always played an important role as places of natural landing and cultural exchange (Di Rita and Melis, 2012). In the Mediterranean, the identification of former land bridges is fundamental to 
understand the migration patterns, notably between the mainland and the islands (e.g., Shackleton et al, 1984, Van Andel, 1989, Antonioli et al., 2014; Dawson, 2016). Furthermore, the Mediterranean islands have been recognized as key regions to study the man-environmental interactions (e.g., Ammerman and Davis, 2013; Ghilardi and Lespez, 2017). This is mainly because they are highly sensitive to climatic and anthropogenic factors (being isolated areas with low resilience, e.g., Fitzhugh and Hunt, 1997; Médail, 2017; Revelles et al., 2019).

The newly assembled RSL record allows us to tentatively reconstruct the shoreline position in the BoS in the last $\sim 10.0 \mathrm{ka}$ BP. At this period (Fig. 5A), the BoS was already form d but its width was smaller than the present one ( $\sim 5$ vs $\sim 11 \mathrm{~km})$. Lavezzi and Cavallo Islands were still onı ${ }^{2} \mathrm{cted}$ to mainland Corsica while a small archipelago was outcropping in correspondence of the S erdı ti banks (Fig. 5A). The Maddalena archipelago was already an insular complex even if its $\mathrm{mr}_{-\mathrm{r}}$ hoi gy was significantly different from the present one. Maddalena, Caprera, and Santo Stefano islands we forming a macro-island placed very close to mainland Sardinia ( $\sim 500 \mathrm{~m}$ in the closest point). I rtt wards, Budelli, Razzoli, and Santa Maria were merged into a single island, together with he Barrettini banks (Fig. 5A). In the northwestern and southeastern portions of the strait, small a1 hipelagos were forming in correspondence of the Moines and Bisce banks.

At $\sim 9$ ka BP (Fig. 5B), we observea a palaeogeography quite similar to the previous one except for the significant submersion of a large pu ${ }^{+}$ion of the Moines, Berrettini, Sperduti and Bisce banks. Between $\sim 10$ and $\sim 8 \mathrm{ka}$ BP, human presen e in Sardinia and Corsica was still very scarce, and limited to individual burial in southern Corsica and som dislocated bones in central-eastern Sardinia (Luglié, 2018). The human migration from mainland to both islands was largely influenced by the permanent insularity condition which Corsica and Sardinia maintained even during the sea-level low-stand at LGM (see Fig. 1A, Modi et al., 2017; Luglié, 2018). Archaeological evidence suggests only sporadic and discontinuous frequentation during Palaeolithic and Mesolithic ages mainly characterized by ephemeral phenomena of seafaring (e.g., Modi et al., 2017; Cherry and Leppard, 2018; Lugliè, 2018). Both archaeological and genetic data indicate the presence of these discontinuous settlements until the transition between Mesolithic and Neolithic ( 8.2 ka BP) followed by a simultaneous beginning of the permanent colonization of both islands at $\sim 7.7$ to $\sim 7.5 \mathrm{ka}$ BP (Luglié, 2018; Tamm et al., 2019). Since that period, our data show that the BoS palaeogeography was 
very similar to the present morphology of the strait (Fig. 5B) with a maximal RSL variation that did not exceed $6.1 \mathrm{~m}$ in the last $7.4 \mathrm{ka} \mathrm{BP}$. The neolithization of Sardinia was associated with the arrival of a genetically-distinct group of immigrants from mainland Europe. This migration path likely connected mainland Italy with northern Corsica via the Tuscan archipelago and finally to Sardinia through the crossing of the BoS (Vigne, 1992, Fig.1A). According to our palaeogeographical reconstruction, crossing the strait for the early Neolithic humans would have required navigation of a minimum of $\sim 6 \mathrm{~km}$ in a meteomarine setting comparable to the present one since the circulation in the BoS is mainly forced by its morphological pattern (see section 2.1, Gérigny et al., 2011, Cucco et al., 2012; Olita et al., 2C15). This seems to support the theory of good navigation skills of the early Neolithic population (Dawson, L01: 2016; Lo Presti et al., 2019). In fact, they were not only able to cross the wide stretches of sea $(.25 \iota \sim 30 \mathrm{~km})$ which separated Elba and Capraia Islands from northern Corsica (Fig. 1A) but also - $\eta_{\eta_{1}}$ lex maritime sectors, such as the BoS, characterized by extreme conditions of wind, waves, and $\mathrm{cv}^{\mathrm{r}} \mathrm{re}_{\mathrm{L}}^{2}{ }^{\mathrm{s}}$ (Gérigny et al. 2015). More generally, our data indicate that the BoS did not represent a signifira. gr ographical barrier. In fact, the two islands have shared comparable demographic histories as $\mathrm{j}$ dicr ed by the similarities in the archaeological record since the Neolithic period (Lugliè, 2017; Tamm eı ^1., 2019).

\section{Conclusions}

The multiproxy investigation carried $\omega^{+}$on both sides of the Bonifacio Strait (southern Corsica-northern Sardinia) allows reconstructing $16 \mathrm{ka}$ of RSL changes. The postglacial sea-level rise triggered the progressive development of a c rucial sea stretch that presently connects the two major basins of the Western Mediterranean.

Our data are of particular interest because they are collected in one of the most tectonically stable areas of the Mediterranean and because minimally affected by compaction-related subsidence. The reconstructed sealevel evolution is thus only influenced by the interplay between eustatic and hydro-isostatic components. Our data indicate that GIA contribution in this portion of the Western Mediterranean did not exceed $0.35 \mathrm{~mm} \mathrm{a}^{-1}$. GIA signal contributes to present-day and future sea-level change and this value should be considered in the computation of future scenarios of sea-level rise of both Corsica and Sardinia.

The comparison between our data and available GIA models indicated that ICE-6G (VM2) model has proved to be the most appropriate to predict the Mid to Late Holocene RSL changes in this sector of the 
Mediterranean. Conversely, we observed a significant misfit of all the available GIA models and the data in Early Holocene.

The palaeogeographic reconstruction indicates that the Bonifacio Strait did not show significant morphological modifications since the RSL stabilization which occurred $\sim 7 \mathrm{ka}$ BP. Since that period, we only observed minimal modifications in the geography of the several insular complexes and archipelagos which occur in the strait. Finally, our data confirm the good navigation ability of the early Neolithic populations which were able to cross one of the most complex sectors still now notorious among sailors for its extreme meteomarine setting.

From a GIA perspective, the regional pattern that arises from the $\mathrm{n}$. ver tataset suggests that the available GIA models should be revised in order to reduce the excess of : ubsidence on the bulk of the west Mediterranean basin. This implies modifications of bot ice-st_..ts . nd 1D earth models. We do not rule out that a 3D non-linear rheology might reconcile predictions anr. ou arvations.

\section{Acknowledgments}

We warmly thank Dr Yuri Donno of the Pe co Nazionale Arcipelago della Maddalena and Alessandro Porqueddu for the support during the fieldwe $k$ in Budelli Island. Part of the fieldwork was carried out in the framework of the second MOPP-Medfisc $d$ roject (INQUA CMP 1603P) meeting in Palau (Sardinia, September 2017) . MV is funded b, the Rita Levi Montalcini programme of the Italian Ministry of University and Research (MIUR). This article contributes to the PCR "Approche géeoarcheologique des paysages de Corse à l'Holoc ne, ı ntre mer et interieur des terres «Tra Mare e Monti »" and "Bouches de Bonifacio" research programm s, funded by the DRAC Corsica and directed by Matthieu Ghilardi and Gael Brkojewitsch, respectively. It is also part of the MISTRALS-PALEOMEX programme of CNRS (INEEINSU scientific departments) and was funded by the ARCHEOMED workshop (Dir. Laurent Lespez). Finally, this project contributes to the project "Cambiamenti climatici e neotettonica - la Sardegna un continente semi-stabile" (L.R. 7/2007 - Unità operativa Università degli Studi di Cagliari) and to the O.C.E.A.N.S. project (Osservatorio Coste E Ambiente Naturale Sottomarino tra Università di Cagliari, Trieste e Provincia di Sassari) both directed by Prof. Sandro DeMuro. Suggestions made by Prof. Gösta Hoffman (University of Bonn) and Dr Elodie Brisset (CNRS IMBE) improved the earlier version of the manuscript. We also extend our gratitude to the PALSEA (INQUA and PAGES working group, the latter 
supported by the Swiss Academy of Sciences and the Chinese Academy of Sciences) and IGCP Project 639 communities for fruitful discussions during the workshops.

Bibliography

Antonioli, F., Lon Presti, V., Morticelli, M. G., Bonfiglio, L., Mannino, M. A., Palombo, M. R., Canese, S. 2016. Timing of the emergence of the Europe-Sicily bridge (40-17 cal ka BP) and its implications for the spread of modern humans. Geological Society, London, Special Publications, 411(1), 111-144.

Amorosi, A., Maselli, V., Trincardi, F. 2016. Onshore to offshore anatomy of a late Quaternary source-tosink system (Po Plain-Adriatic Sea, Italy). Earth-Science Reviews, 153, 212-237.

Amorosi, A., Rossi, V., Scarponi, D., Vaiani, S.C., Ghosh, A., 2014. Biosedimentary record of postglacial coastal dynamics: high-resolution sequence stratigraphy from the norte । Tuscan coast (Italy). Boreas 43, 939-954.

Athersuch, J., Horne, D.J. and Whittaker, J.E. 1989. Marine and brac ish water ostracods, in: Synopses of the British Fauna (New 5 Series), 43, Kermack, D.M. and Barnes, R.S.K. (Eds.), Brill E.J., Leiden, 345 pp.

Benjamin J., Rovere, A., Fontana, A., Furlani, S., Vacchi, M., L.glis, R., Galili, E., Antonioli, F., Sivan, D. Miko, S., Felja, I., Meredith-Williams, M., Goodman, 3., ^.nzidei, M., Gehrels, R. 2017. Late Quaternary sea-level change and early human societies is central and eastern Mediterranean Basin: an interdisciplinary review. Quaternary Internationa: 49, 29-57.

Boetto, G. 2012. Les épaves comme sources nour l'étude de la navigation et des routes commerciales: une approche méthodologique. Rome, portus a $1 d$ is $\rightleftharpoons$ Mediterranean, 153-173.

Brisset, E., Burjachs, F., Navarro, B. I. I de Pablo, J. F. L. 2018. Socio-ecological adaptation to EarlyHolocene sea-level rise in the weste. Meuiterranean. Global and planetary change, 169, 156-167.

Bruno, L., Campo, B., Costagli, B., ¿`outhamer, E., Teatini, P., Zoccarato, C., Amorosi, A. 2020. Factors controlling natural subsidence in $i$ e Po Plain. Proceedings of the International Association of Hydrological Sciences, 382, 285-290.

Buosi, C., Châtelet, E. A. J., Cherchi, A. (2012). Benthic foraminiferal assemblages in the currentdominated Strait of Bonifacio (Mediterranean Sea). The Journal of Foraminiferal Research, 42(1), 39-55.

Buurman, P., Pape, T., Muggler C.C. 1996. Laser grain-size determination in soil genetic studies: Practical problems. Soil Science 162 (3), 211-218.

Carmignani, L., Oggiano, G., Funedda, A., Conti, P., Pasci, S. 2016. The geological map of Sardinia (Italy) at 1: 250,000 scale. Journal of Maps, 12(5), 826-835.

Chelli, A., Pappalardo, M., Bini, M., Brückner, H., Neri, G., Neri, M., Spada, G. 2017. Assessing tectonic subsidence from estimates of Holocene relative sea-level change: An example from the NW Mediterranean (Magra Plain, Italy). The Holocene, 27(12), 1988-1999. 
Cherry, J. F., Leppard, T. P. 2018. Patterning and its causation in the pre-Neolithic colonization of the Mediterranean islands (Late Pleistocene to Early Holocene). The Journal of Island and Coastal Archaeology, 13(2), 191-205.

Cucco, A., Sinerchia, M., Ribotti, A., Olita, A., Fazioli, L., Perilli, A., Sorgente, R. 2012. A high-resolution real-time forecasting system for predicting the fate of oil spills in the Strait of Bonifacio (western Mediterranean Sea). Marine pollution bulletin, 64(6), 1186-1200.

Currás, A., Ghilardi, M., Peche-Quilichini, K., Fagel, N., Vacchi, M., Delanghe, D., Ottaviani, J. C. 2017. Reconstructing past landscapes of the eastern plain of Corsica (NW Mediterranean) during the last 6000 years based on molluscan, sedimentological and palynological analyses Journal of Archaeological Science: Reports, 12, 755-769.

Dawson, H., 2011. Island colonisation: Settling the Neolithic quest. ^n N. Phoca-Cosmetatou (Ed.), The First Mediterranean Islanders: Initial Occupation and Survival Stra ${ }^{+\wedge}$ - $k$. vol. 74, University of Oxford School of Archaeology, Monograph, pp. 31-54

Dawson, H. 2016. Mediterranean voyages: The $2 \mathrm{rc}^{2} \mathrm{de}$ logy of island colonisation and abandonment. Mediterranean Voyages: The Archaeology II Island Colonisation and Abandonment. Institute of Archaelogical Publications 62vol. 400, Left Coas، ${ }^{\circ}$ ress

De Boer, B., Stocchi, P., Van De Wal, F. _ ^14. A fully coupled 3-D ice-sheet-sea-level model: algorithm and applications. Geoscientific Model $\Gamma$ c alupment, 7(5), 2141-2156.

De Falco, G., De Muro, S., Batzelia, T., Cucco, A. 2011. Carbonate sedimentation and hydrodynamic pattern on a modern temperate shelf: The ${ }^{+*}$ it of Bonifacio (western Mediterranean). Estuarine, Coastal and Shelf Science, 93(1), 14-26.

De Muro, S., Batzella, T., De Falco, G., Porta, M., 2010. Sedimentological map of Bonifacio Strait inner shelf. Rendiconti Online Società Geologica Italiana, 11(2), 752-753.

De Muro, S. 1990. Dinamica dei litorali e Geomorfologia della Piattaforma prossimale tra Capo Testa e Punta di li Francesi (Sardegna settentrionale). Phd thesis, University of Trieste. 526 pp.

De Muro, S., Orrù, P. 1998. Il contributo delle Beach-Rock nello studio della risalita del mare olocenico. Le Beach-Rock post-glaciali della Sardegna nord-orientale. Il Quaternario 11(1), 19-39.

Desruelles, S., Fouache, É., Ciner, A., Dalongeville, R., Pavlopoulos, K., Kosun, E., Coquinot, Y., Potdevin, J. L. 2009. Beachrocks and sea level changes since Middle Holocene: comparison between the insular group 
of Mykonos-Delos-Rhenia (Cyclades, Greece) and the southern coast of Turkey. Global and Planetary Change, 66(1-2), 19-33.

D’Orefice, M., Bellotti, P., Bertini, A., Calderoni, G., Censi Neri, P., Di Bella, L., .. Vittori, C. 2020. Holocene Evolution of the Burano Paleo-Lagoon (Southern Tuscany, Italy). Water, 12(4), 1007.

Engelhart, S. E., Vacchi, M., Horton, B. P., Nelson, A. R., Kopp, R. E. 2015. A sea-level database for the Pacific coast of central North America. Quaternary Science Reviews 113, 78-92.

Faccenna, C., Becker, T. W., Auer, L., Billi, A., Boschi, L., Brun, J.P., Capitanio, F.A., Funiciello, F., Horvàth, F., Jolivet L., Piromallo, C., Royden, L., Rossetti, F., Serpel'sni, E. 2014. Mantle dynamics in the Mediterranean. Reviews of Geophysics 52(3), 283-332.

Farrell, W. E., Clark, J. A. 1976. On postglacial sea level. Geophys ical .ournal International, 46(3), 647-667.

Fitzhugh, B., Hunt, T. L. 1997. Introduction: Islands as labor tton s: Archaeological research in comparative perspective. Human Ecology, 379-383.

Furlani, S., Pappalardo, M., Gómez-Pujol, L., Chel: A. 2014. The rock coast of the Mediterranean and Black seas. Geological Society, London, Memc rs, .0(1), 89-123.

Gérigny, O., Coudray, S., Lapucci, C., Toma ino, C., Bisgambiglia, P. A., Galgani, F. 2015. Small-scale variability of the current in the Strait of Boni ac 10. Ocean Dynamics, 65(8), 1165-1182.

Ghilardi, M., Istria, D., Curras, A., V cchı, M., Contreras, D., Vella, C., Dussouillez, P., Crest, Y., Guiter, F., Delanghe, D. 2017. Reconstructing th. landscape evolution and the human occupation of the Lower Sagone River (Western Corsica, Frar ce) 'rom the Bronze Age to the Medieval period. Journal of Archaeological Science: Reports, 12, 741-75

Ghilardi M., Lespez L., 2017. Geoarchaeology of the Mediterranean islands: from « Lost worlds » to vibrant places. In Ghilardi M. and Lespez L. (eds.), Geoarchaeology of the Mediterranean islands, Journal of Archaeological Science: Reports, 12, 735-740

Giaime, M., Morhange, C., Ontiveros, M. Á. C., Fornós, J. J., Vacchi, M., Marriner, N. 2017. In search of Pollentia's southern harbour: Geoarchaeological evidence from the Bay of Alcúdia (Mallorca, Spain). Palaeogeography, palaeoclimatology, palaeoecology, 466, 184-201.

Guillot, F. 1997. La grotta di Sant Elmo o" Grotta Verde" in Alghero. Revista de l'Alguer, 8(8), 81-92.

Heiri, O., Lotter, A.F., Lemcke, G., 2001. Loss on ignition as a method for estimating organic and carbonate content in sediments: reproducibility and comparability of results. Journal of Paleolimnology 25, 101-110. 
Hijma, M., Engelhart, S.E., Tornqvist, T.E., Horton, B.P., Hu, P., Hill, D., 2015. A protocol for a geological sea-level database. In: Shennan, I., Long, A., Horton, B.P. (Eds.), Handbook of Sea Level Research. Wiley, pp. 536-553.

Iacono, R., Napolitano, E., Marullo, S., Artale, V., and Vetrano, A.: Seasonal variability of the tyrrhenian sea surface geostrophic cir- culation as assessed by altimeter data, J. Phys. Oceanogr., 43, 1710-1732, 2013

Karkani, A., Evelpidou, N., Vacchi, M., Morhange, C., Tsukamoto, S., Frechen, M., Maroukian, H. 2017. Tracking shoreline evolution in central Cyclades (Greece) using beachrocks. Marine Geology, 388, 25-37.

Khan, N. S., Ashe, E., Shaw, T. A., Vacchi, M., Walker, J., Peltier, W. R., Kopp, R.E., Horton, B. P. 2015. Holocene Relative Sea-Level Changes from Near-, Intermediate-, and Far- Field Locations. Current Climate Change Reports 1(4), 247-262.

Khan, N. S., Horton, B. P., Engelhart, S., Rovere, A., Vacchi, M., Ashe, E. L., Shennan, I. 2019. Inception of a global atlas of sea levels since the Last Glacial Maximum. "'uate rnary Science Reviews, 220, 359-371.

Laborel, J., Morhange, C., Lafont, R., Le Campion, J. Ia orel-Deguen, F., Sartoretto, S. 1994. Biological evidence of sea-level rise during the last $4500 \mathrm{y}^{-}$- $s \mathrm{~s}$ ? the rocky coasts of continental southwestern France and Corsica. Marine Geology 120(3), 203-223.

Lambeck, K., Purcell, A. 2005. Sea-lev \&. cr.nge in the Mediterranean Sea since the LGM: model predictions for tectonically stable areas. Oui te nary Science Reviews, 24(18-19), 1969-1988.

Lambeck, K., Antonioli, F., Anzidei, _^, Ferranti, L., Leoni, G., Scicchitano, G., Silenzi, S. 2011. Sea level change along the Italian coast du.ing the Holocene and projections for the future. Quaternary International, 232(1-2), 250-257.

Lambeck, K., Rouby, H., Purcell, A., Sun, Y., Sambridge, M. 2014. Sea level and global ice volumes from the Last Glacial Maximum to the Holocene. Proceedings of the National Academy of Sciences 111(43), 15296-15303.

Le Bourdonnec, F. X., Poupeau, G., Lugliè, C., D’Anna, A., Bellot-Gurlet, L., Bressy-Leandri, C. S., Pasquet, A., Tramoni, P. 2011. New data and provenance of obsidian blocks from Middle Neolithic contexts on Corsica (western Mediterranean). Comptes Rendus Palevol 10(4), 259-269.

Lewthwaite, J. 1990. Isolating the residuals: The Mesolithic basis of man-animal relationships on the Mediterranean islands. The Mesolithic in Europe. International Symposium 3. pp. 541-555. 
Lo Schiavo, F., 1987. Grotta Verde 1979: un contributo sul neolitico antico della Sardegna Atti della XXVI Riunione Scientifica dell'Istituto Italiano di Preistoria e Protostoria, pp. 845e858.

Lo Presti, V., Antonioli, F., Palombo, M.R., Agnesi, V., Biolchi, S., Calcagnile, L., Pepe, F. 2019. Palaeogeographical evolution of the Egadi Islands (western Sicily, Italy). Implications for late Pleistocene and early Holocene sea crossings by humans and other mammals in the western Mediterranean. EarthScience Reviews 194, 160-181

Lugliè, C. 2018. Your path led trough the sea... the emergence of Neolithic in Sardinia and Corsica. Quaternary International, 470, 285-300.

Marriner, N., Gambin, T., Djamali, M., Morhange, C., Spiteri, M. 2017 Livarchaeology of the Burmarrad ria and early Holocene human impacts in western Malta. Pal eogeography, Palaeoclimatology, Palaeoecology, 339, 52-65.

Marriner, N., Flaux, C., Morhange, C., Kaniewski, D. 20?. N ile Delta's sinking past: Quantifiable links with Holocene compaction and climate-driven changes in se dimen. supply?. Geology, 40(12), 1083-1086.

Marriner, N., Morhange, C., Faivre, S., Flaux, C, ' $/ a$ a hi, M., Miko, S., Rossi, I. R. 2014. Post-Roman sealevel changes on Pag Island (Adriatic Sea): L ${ }^{\imath^{+}}$ng Croatia's "enigmatic" coastal notch? Geomorphology 221, 83-94.

Mauz, B., Vacchi, M., Green, A., Hoffma.'n, G., Cooper, A. 2015. Beachrock: A tool for reconstructing relative sea level in the far-field. Marne Teology 362, 1-16.

Marco-Barba, J., Holmes, J. A., 1.'esc uita-Joanes, F., Miracle, M. R. 2013. The influence of climate and sealevel change on the Holoce ne $\mathrm{f}$ volution of a Mediterranean coastal lagoon: evidence from ostracod palaeoecology and geochemist '. Geobios, 46(5), 409-421.

Milne, G. A., Mitrovica, J. X. 1998. Postglacial sea-level change on a rotating Earth. Geophysical Journal International 133(1), 1-19.

Milne, G.A., Long, A.J., Bassett, S.E., 2005. Modeling Holocene relative sea-level observations from the Caribbean and South America. Quaternary Science Reviews 24, 1183-1202.

Medail F., 2017. The specific vulnerability of plant biodiversity and vegetation on Mediterranean islands in the face of global change. Regional Environmental Change, Springer Verlag, 17 (6),1775-1790.

Medas, S. 2005. La navigazione di Posidonio dall'Iberia all'Italia e le rotte d'altura nel Mediterraneo occidentale in età romana. Mayurqa, 30(2), 577-610. 
Melini, D., Spada, G. 2019. Some remarks on Glacial Isostatic Adjustment modelling uncertainties. Geophysical Journal International, 218(1), 401-413.

Modi, A., Tassi, F., Susca, R. R., Vai, S., Rizzi, E., De Bellis, G., Lugliè, C., Gonzales Fortes, G., Lari, M., Barbujani, G., Caramelli, D., Ghirotto, S., 2017. Complete mitochondrial sequences from Mesolithic Sardinia. Scientific reports, 7,42869

Montefalcone, M., Vacchi, M., Carbone, C., Cabella, R., Schiaffino, C. F., Elter, F. M., Morri, C., Bianchi, C.n., Ferrari, M. 2016. Seagrass on the rocks: Posidonia oceanica settled on shallow-water hard substrata withstands wave stress beyond predictions. Estuarine, Coastal and Shelf Science, 180, 114-122.

Morhange, C., Marriner, N., Excoffon, P., Bonnet, S., Flaux, C., Zihrnw: 's, H., ... Amouri, M. E. 2013. Relative sea-level changes during Roman times in the northwest Mt dite' ranean: The 1st century AD fish tank of Forum Julii, Fréjus, France. Geoarchaeology, 28(4), 363-3; ?

Morhange, C., Pirazzoli, P. A., Marriner, N., Montaggioni, L F., Nammour, T. 2006. Late Holocene relative sea-level changes in Lebanon, Eastern Mediterranean. Mari.e Geulogy, 230(1-2), 99-114.

Nesteroff, W. D. 1984. Étude de quelques grès 'a $r^{1}$ qge du sud de la Corse: datations ${ }^{14} \mathrm{C}$ et implications néotectoniques pour le bloc corso-sarde. Travau. ' $’$ e la Maison de l'Orient 8(1), 99-111.

Nocquet, J. M. 2012. Present-day kinem ins of the Mediterranean: A comprehensive overview of GPS results. Tectonophysics, 579, 220-242.

Oggiano, G., Funedda, A., Carmignalı, L., Pasci, S. 2009. The Sardinia-Corsica microplate and its role in the Northern Apennine Geodyna nic ;: new insights from the Tertiary intraplate strike-slip tectonics of Sardinia. Bollettino della Soci tà ( əologica Italiana, 128(2), 527-539.

Olita, A., Iermano, I., Faziol, L., Ribotti, A., Tedesco, C., Pessini, F., Sorgente, R. 2015. Impact of currents on surface flux computations and their feedback on dynamics at regional scales. Ocean Science, 11(4).

Opdebeeck, J. 2005. Shipwrecks and amphorae: Their relationship with trading routes and the Roman economy in the Mediterranean (Doctoral dissertation, University of Southampton). $59 \mathrm{pp}$.

Ozer, A., Tucci, S., Ulzega, A. 1984. Les beach-rocks de Sardaigne. Distribution et implications paléogéographiques. MOM Éditions, 8(1), 113-124.

Palombo, M.R., Antonioli, F., Lo Presti, V., Mannino, M.A., Melis, R.T., Orru, P., Stocchi, P., Talamo, S., Quarta, G., Calcagnile, L., Deiana, G., 2017. The Late Pleistocene to Holocene palaeogeographic evolution 
of the Porto Conte area: clues for a better understanding of human colonisation of Sardinia and faunal dynamics during the last $30 \mathrm{ka}$. Quaternary International, 439,117-140.

Peltier, W.R., 2004. Global glacial isostasy and the surface of the ice-age earth: the ice-5G (VM2) model and grace. Annual Review of Earth and Planetary Sciences 32, 111-149.

Peltier, W. R., Argus, D. F., Drummond, R. 2015. Space geodesy constrains ice age terminal deglaciation: The global ICE-6G_C (VM5a) model. Journal of Geophysical Research: Solid Earth, 120(1), 450-487.

Péres, J.-M., 1982. Major benthic assemblages. In: Kinne, O. (Ed.), Marine Ecology, vol. 5, part 1. Wiley, Chichester, pp. 373-522.

Péres, J.-M., Picard, J., 1964. Nouveau manuel de bionomie benthique de li mer Méditerranée. Recherche et travaux de la Station Marine Endoume, vol. 31. Marseille.

Pirazzoli, P. A. 2005. A review of possible eustatic, iso tatic and tectonic contributions in eight lateHolocene relative sea-level histories from the Mediterranea`ar. Quaternary Science Reviews, 24(18-19), 1989-2001.

Reimer, P.J., Bard, E., Bayliss, A., Beck, J.W. B1 ،ckwell, P.G., Bronk Ramsey, C.,Buck, C.E., Cheng, H., Edwards, R.L., Friedrich, M., Grootes, P.M. Guildeı son, T.P., Haflidason, H., Hajdas, I., Hatta, C., Heaton, T.J., Hogg, A.G., Hughen, K.A., Kaise, K.r., Kromer, B., Manning, S.W., Niu, M., Reimer, R.W., Richards, D.A.,Scott, E.M., Southon, J.P T r.ey, C.S.M., van der Plicht, J., 2013. IntCal13 andMARINE13 radiocarbon age calibration curves 0-50000 years cal BP. Radiocarbon 55.http://dx.doi.org/10.2458/azu_js_...2..16947

Revelles, J., Ghilardi, M R ssi, V., Currás, A., López-Bultó, O., Brkojewitsch, G., Vacchi, M. 2019. Coastal landscape evolution o: Corsica island (W. Mediterranean): palaeoenvironments, vegetation history and human impacts since the early Neolithic period. Quaternary Science Reviews, 225, 105993

Reynolds, P. 2010. Hispania and the Roman Mediterranean, AD 100-700: ceramics and trade (p. 120156). London: Duckworth.

Rovere, A., Parravicini, V., Vacchi, M., Montefalcone, M., Morri, C., Bianchi, C. N., Firpo, M. 2010. Geoenvironmental cartography of the marine protected area "Isola di Bergeggi"(Liguria, NW Mediterranean Sea). Journal of Maps 6(1), 505-519.

Rossi, V., Amorosi, A., Sarti, G., Potenza, M. 2011. Influence of inherited topography on the Holocene sedimentary evolution of coastal systems: an example from Arno coastal plain (Tuscany, Italy). Geomorphology, 135(1-2), 117-128. 
Rossi, V., Amorosi, A., Sarti, G., Mariotti, S., 2017. Late Quaternary multiple incised valley systems: an unusually well-preserved stratigraphic record of two interglacial valley-fill successions from the Arno plain (northern Tuscany, Italy). Sedimentology 64, 1901-1928.

Roy, K., Peltier, W. R. 2018. Relative sea level in the Western Mediterranean basin: A regional test of the ICE-7G_NA (VM7) model and a constraint on Late Holocene Antarctic deglaciation. Quaternary Science Reviews, 183, 76-87.

Secci, M., Giarrusso, C., Nieddu, G., Porqueddu, A., Spanu, P. 2013. The Maddalena Archipelago Maritime Target Survey: A Collaborative Effort toward the Enhancement of Maritime Cultural Heritage. Underwater Archaeology Proceedings 2013. 93-103.

Salel, T., Bruneton, H., Lefèvre, D. 2016. Ostracods and environm. nt?, variability in lagoons and deltas along the north-western Mediterranean coast (Gulf of Lions, F anc, and Ebro delta, Spain). Revue de Micropaléontologie, 59(4), 425-444.

Serpelloni, E., Faccenna, C., Spada, G., Dong, D., William., S. L. 2013. Vertical GPS ground motion rates

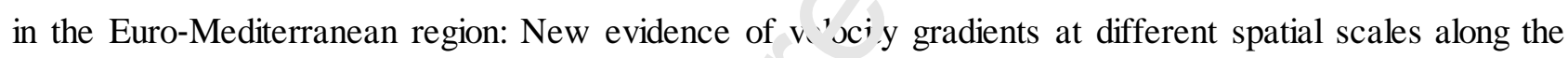
Nubia-Eurasia plate boundary. Journal of Geoph, sk 1 l is search: Solid Earth 118(11), 6003-6024.

Shackleton, J. C., Van Andel, T. H., Runneis, C. N. 1984. Coastal paleogeography of the central and western Mediterranean during the last $125,00 \mathrm{C} \sim \mathrm{rs}$ and its archaeological implications. Journal of field Archaeology, 11(3), 307-314.

Shennan, I. 1986. Flandrian sea-i- ve changes in the Fenland. II: Tendencies of sea-level movement, altitudinal changes, and local and re-..Jnal factors. Journal of Quaternary Science 1(2), 155-179.

Shennan, I., Long, A. J., Horto, B. P. 2015. Handbook of sea-level research. John Wiley \& Sons.

Shennan, I., Horton, B., 2002. Holocene land- and sea-level changes in Great Britain. Journal of Quaternary Science 17, 511-526.

Siani, G., Paterne, M., Michel, E., Sulpizio, R., Sbrana, A., Arnold, M., Haddad, G. 2001. Mediterranean Sea surface radiocarbon reservoir age changes since the last glacial maximum. Science 294(5548), 1917-1920.

Sornoza, L., Barnolas, A., Arasa, A., Maestro, A., Rees, J. G., Hernández-Molina, F. J. 1998. Architectural stacking patterns of the Ebro delta controlled by Holocene high-frequency eustatic fluctuations, delta-lobe switching and subsidence processes. Sedimentary Geology, 117(1-2), 11-32. 
Sorgente, B., Sorgente, R., Olita, A., Fazioli, L., Cucco, A., Perilli, A., Sinercha, M., Ribotti, A. 2012. Effects of protection rules and measures in an important international strait area: the Bonifacio Strait. Journal of Operational Oceanography, 5(1), 35-44

Spada, G., Antonioli, A., Cianetti, S., Giunchi, C. 2006. Glacial isostatic adjustment and relative sea-level changes: the role of lithospheric and upper mantle heterogeneities in a 3-D spherical Earth. Geophysical Journal International, 165(2), 692-702.

Spada, G., Melini, D. 2019. On Some Properties of the Glacial Isostatic Adjustment Fingerprints. Water, 11(9), 1844.

Spada, G., Stocchi, P. 2007. SELEN: A Fortran 90 program for solvin the "sea-level equation". Computers $\&$ Geosciences 33(4), 538-562.

Stocchi, P., Spada, G. 2009. Influence of glacial isostatic adjusth ${ }^{\text {'nt }}$ upon current sea level variations in the Mediterranean. Tectonophysics 474(1), 56-68.

Stocchi, P., Vacchi, M., Lorscheid, T., de Boer, B., Sinn ss, A. R., van de Wal, R. S., Pappalardo, M., Rovere, A. 2018. MIS 5e relative sea-level cr_ac in the Mediterranean Sea: Contribution of isostatic disequilibrium. Quaternary Science Reviews, $1 c^{5}$.22-134.

Stuiver, M., Polach, H.A., 1977. Reporting ${ }^{14} \mathrm{C}$ u. ta. Radiocarbon 19, 355-363.

Tamm, E., Di Cristofaro, J., Mazières, `., Ptnnarun, E., Kushniarevich, A., Raveane, A., Montinaro, F. 2019. Genome-wide analysis of Corsic?n $n_{\text {, }}$ pulation reveals a close affinity with Northern and Central Italy. Scientific reports, 9(1), 1-10.

Thierry, S., Dick, S., Geory S., Benoit, L., Cyrille, P. 2019. EMODnet Bathymetry a compilation of bathymetric data in the Europuan waters. In OCEANS 2019-Marseille. pp. 1-7.

Tomassetti, L., Brandano, M. 2013. Sea level changes recorded in mixed siliciclastic-carbonate shallowwater deposits: The Cala di Labra Formation (Burdigalian, Corsica). Sedimentary Geology, 294, 58-67.

Tornqvist, T.E., Rosenheim, B.E., Hu, P., Fernandez, A.B., 2015. Radiocarbon dating and calibration. In: Shennan, I., Long, A.J., Horton, B.P. (Eds.), Handbook of Sea- level Research. Wiley, pp. 349-360.

Vacchi, M., Ghilardi, M., Melis, R. T., Spada, G., Giaime, M., Marriner, N., Morhange C., Rovere, A. 2018. New relative sea-level insights into the isostatic history of the Western Mediterranean. Quaternary Science Reviews, 201, 396-408. 
Vacchi, M., Ghilardi, M., Spada, G., Currás, A., Robresco, S. 2017. New insights into the sea-level evolution in Corsica (NW Mediterranean) since the late Neolithic. Journal of Archaeological Science: Reports, 12, 782-793.

Vacchi, M., Marriner, N., Morhange, C., Spada, G., Fontana, A., Rovere, A. 2016. Multiproxy assessment of Holocene relative sea-level changes in the western Mediterranean: Sea-level variability and improvements in the definition of the isostatic signal. Earth-Science Reviews 155, 172-197.

Vacchi, M., Rovere, A., Zouros, N., Desruelles, S., Caron, V., Firpo, M. 2012. Spatial distribution of sealevel markers on Lesvos Island (NE Aegean Sea): evidence of differential relative sea-level changes and the neotectonic implications. Geomorphology, 159, 50-62.

Vacchi, M., Russo Ermolli, E.., Morhange, C., Ruello, M. R., Di Don. `n. J., Di Vito, M. A., Giampaola, D., Carsana, V., Liuzza, V., Cinque, A., Boetto, G., Poveda, P.. I'nen i, G., Marriner, N. 2019. Millennial variability of rates of sea-level rise in the ancient harbour of $\mathrm{Na}_{a_{1}}$ les (Italy, western Mediterranean Sea). Quaternary Research, 1-15.

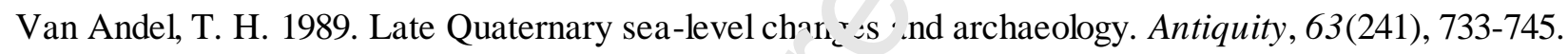

Vigne, J. D. 1992. Zooarchaeology and the bios'` graphical history of the mammals of Corsica and Sardinia since the last ice age. Mammal Review, 22( $), 87-96$.

Vigne, J.-D., Thibault, J.-C., Cheylan ( : 1994. L'archipel des Lavezzi: présentation, histoire des

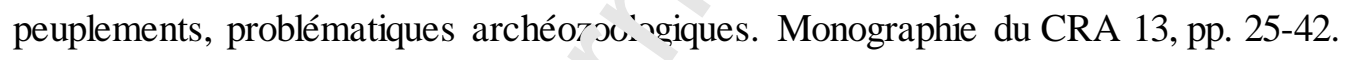

Figure and table captions:

Figure 1: A) Geographical pu ition of Corsica and Sardinia in the western Mediterranean and approximate location of the palaeoshoreline at the Last Glacial Maximum (LGM, red line). BoS is Bonifacio Strait, EB is Elba Island; CR is Capraia Island. B) Tectonic framework of the study area (modified after Stocchi et al, 2018), red lines indicate the major faults according to Faccenna et al. (2014). C) Location of the coring sites (red squares) beachrock sampling (white squares). MN is Moines, CL is Cala Lunga, PT is Piantarella, CV is Cavallo, BD is Budelli, CT is Capo Testa and TM is Tanca Manna. Satellite Imagery in panel C) from Google Earth (Google, Maxar Technologies, SIO, NOAA, U.S. Navy, NGA, GEBCO).

Figure 2. A) Geographic position, stratigraphy and ${ }^{14} \mathrm{C}$ dating of the units defined for the Piantarella lagoon cores (P1, P2, P3). B) Geographic position, stratigraphy and ${ }^{14} \mathrm{C}$ dating of the units defined for the Budelli 
cores (B1, B2, B3). NGF is the French National Geodetic datum which is presently placed $0.12 \mathrm{~m}$ below the msl. In B1 core, the presence of in situ fossil Posidonia oceanica matte is showed. Satellite imagery from Google Earth (Google, 2014).

Figure 3. Spatial extent and bathymetric distribution of the different beachrock levels measured in Tanca Manna (A, C, D) and Cala Lunga (B, E, F); depth is expressed in $\mathrm{m}$ below the msl and distance is expressed in $\mathrm{m}$ from the shoreline. The age of the deepest slabs is expressed in calibrated years BP. Thin section (crosspolarized light) of the beachrock samples in Cala Lunga $(\mathrm{G}, \mathrm{H})$ and Tanca Manna $(\mathrm{J}, \mathrm{H})$ a) small bladed isopachous fringe of limpid and contiguous HMC crystals; b) irregularly haped intertidal micritic cement; c) peloidal cements; d) radial fibrous HMC calcite. Satellite imagery frot ' Go gle Earth (Google, 2014 and Maxar Technologies, 2020).

Figure 4. Holocene RSL reconstruction for the BoS coasts. K، $\mathrm{d}$ br xes are the sedimentary (sed.) Sea Level Index Points (SLIPs) produced in this study. Grey boxe at the sedimentary (sed.) SLIPs available in the Vacchi et al., 2018 RSL database (V18). Blue fil ${ }_{-\mu}$ bo ${ }^{2} \mathrm{~s}^{\mathrm{s}}$ are the beachrock (bcrk) SLIPs produced in this study. Grey filled boxes are bcrk SLIPs available $1_{\star}$ the V18 database. Filled blue triangles are the

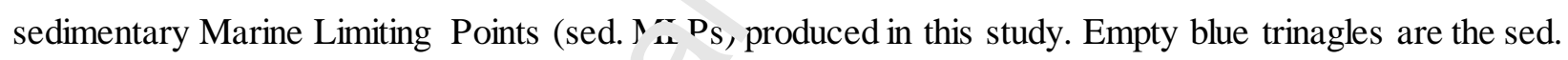
MLPs available in the V18 database. D mu.'sions of boxes and lines for each point based on 2 s elevation and age errors. The RSL record comparea n four GIA predictions: black lines is IC5-5G (VM2), red line is the ICE-6G (VM2), green line is th $\mathrm{A}_{1} \mathrm{TE}-\mathrm{SELEN}(\mathrm{VM} 2)$ and blue line is K33 (see section 3.5).

Figure 5. Palaeogeographical $\mathrm{rt}$ zonstruction of the BoS shoreline position (red line) at $\sim 10 \mathrm{ka}$ (A), $9 \mathrm{ka}$ (B), and $\sim 7 \mathrm{ka}(\mathrm{C}) \mathrm{BP}$. Black line indicates the modern shoreline position while red line show the position of the palaeoshoreline. Yellow triangles show the indicative position of Mesolithic settlements while brown squares show the early Neolithic setllements (modified from Lugliè, 2018). Mn is Moines bank, cv is Cavallo Island, lv is Lavezzi Island, sp is Sperduti bank, rz is Razzoli Island, $\mathrm{mr}$ is Santa Maria Island, bd is Budelli Island, br is Berrettini bank, sp is Spargi, md is La Maddalena Island, st is Santo Stefano Island, cp is Caprera Island, bs is Bisce bank.

Table 1. The new dataset of Sea-Level Index Points (SLIP) and Marine Limiting Points (MLP) from the Bonifacio Strait. P is Piantarella (core 1, 2 and 3); B is Budelli (core 1,2 and 3); TC is Tanca Manna; CL is 
Cala Lunga. IR is the Indicative range. Elevation is expressed in $\mathrm{m}$ above mean sea level (msl). The final error includes the sampling and leveling errors and, for SLIPs, the indicative range.

Table 2. Sea Level Index Points (SLIP) and Marine Limiting Points (MLP) from the Bonifacio Strait extracted from the V18 database (Vacchi et al., 2018).

Appendix 1. Results of the grain-size analysis performed on the Budelli cores.

\begin{tabular}{|c|c|c|c|c|c|c|c|c|}
\hline Elevation (m msl) & Site & Lab code & Material & ${ }^{14} \mathrm{C}$ date & Cal BP & Error & Facies & IR \\
\hline-0.55 & $\mathrm{P} 1$ & Poz-96451 & P. oceanica & $1230 \pm 40$ & 757 & 94 & Brackish swamp & msl to \pm 0.5 \\
\hline-1.67 & $\mathrm{P} 1$ & Beta-479673 & P. oceanica & $4230 \pm 30$ & $4 . \cdots j$ & 106 & Open lagoon & $\mathrm{msl}$ to $-2 \mathrm{~m}$ \\
\hline-4.89 & $\mathrm{P} 1$ & Beta-479674 & P. oceanica & $6660 \pm 30$ & 716. & 87 & Shallow marine & below msl \\
\hline-6.01 & $\mathrm{P} 1$ & Poz-96321 & C. vulgatum & $6930 \pm 50$ & $\neg 408$ & 101 & Shallow marine & below msl \\
\hline-0.51 & $\mathrm{P} 2$ & SacA-54013 & P. oceanica & $740 \pm 30$ & 358 & 73 & Brackish swamp & $\mathrm{msl}$ to \pm 0.5 \\
\hline-1.03 & $\mathrm{P} 2$ & SacA-54014 & C. vulgatum & $449 C \cdot 30$ & 4658 & 121 & Semi enclosed lagoon & $\mathrm{msl}$ to $-1 \mathrm{~m}$ \\
\hline-1.58 & $\mathrm{P} 2$ & Poz-101157 & C. vulgatum & $\Delta 526 \pm 40$ & 4685 & 123 & Marine & below msl \\
\hline-2.17 & $\mathrm{P} 2$ & Poz-101152 & C. glaucum & $57 r \pm 35$ & 4687 & 117 & Marine & below msl \\
\hline-2.59 & P3 & Poz-101153 & C. gla cum & $J 195 \pm 35$ & 5524 & 71 & Semi enclosed lagoon & $\mathrm{msl}$ to $-1 \mathrm{~m}$ \\
\hline-2.83 & P3 & Poz-101154 & C glaucum & $5550 \pm 40$ & 5890 & 113 & Semi enclosed lagoon & $\mathrm{msl}$ to $-1 \mathrm{~m}$ \\
\hline-3.53 & P3 & Poz-101155 & $C$ slau $m$ & $5950 \pm 40$ & 6344 & 83 & Semi enclosed lagoon & $\mathrm{msl}$ to $-1 \mathrm{n}$ \\
\hline-3.81 & P3 & Poz-101156 & C. ${ }^{-1}$ ucum & $6260 \pm 60$ & 6682 & 156 & Semi enclosed lagoon & msl to $-1 n$ \\
\hline-0.82 & B1 & Poz-77839 & P. oceanica & $2970 \pm 35$ & 2721 & 120 & Marine & below msl \\
\hline-1.22 & B2 & Poz-7784c & P. oceanica & $3790 \pm 35$ & 3698 & 131 & Marine & below msl \\
\hline-0.67 & B2 & Po $-1,71$ & Organics & $2355 \pm 30$ & 2405 & 77 & Brackish swamp & msl to \pm 0.5 \\
\hline-1.27 & B3 & $1.7-1 / 844$ & Organics & $3165 \pm 30$ & 3364 & 87 & Brackish swamp & $\mathrm{msl}$ to \pm 0.5 \\
\hline-0.82 & B3 & Poz-77842 & Organics & $285 \pm 30$ & 308 & 149 & Brackish swamp & $\mathrm{msl}$ to \pm 0 \\
\hline-3.8 & TM & Beta -510792 & Tellinidae spp & $6050 \pm 30$ & 6435 & 123 & Intertidal beachrock & $\mathrm{msl}$ to \pm 0.2 \\
\hline-3.7 & CL & Beta - 510793 & Conidae spp & $5920 \pm 30$ & 6307 & 97 & Intertidal beachrock & $\mathrm{msl}$ to \pm 0.2 \\
\hline
\end{tabular}

Table 1.

\begin{tabular}{ccccccccc} 
Site & Lab code & Reference & Sample & Age cal & Error & RSL & Error & Type \\
\hline Cavallo Is. & Poz-60044 & Poher et al.. 2017 & Organics & 819 & 90 & -0.9 & 0.21 & MLP \\
Cavallo Is. & Poz-66300 & Poher et al.. 2017 & Organics & 2163 & 146 & -1.4 & 0.21 & MLP \\
Cavallo Is. & Poz-66301 & Poher et al.. 2017 & Organics & 3609 & 99 & -0.8 & 1.0 & SLIP
\end{tabular}




$\begin{array}{cccccccc}\text { Cavallo Is. } & \text { Poz-60045 } & \text { Poher et al.. 2017 } & \text { Organics } & 4495 & 73 & -1.8 & 0.5 \\ \text { Capo Testa } & \text { na } & \text { De Muro and Orrù. 1998 } & \text { Beachrock } & 9815 & 329 & -29.5 & 2.1 \\ \text { Moines } & \text { na } & \text { De Muro and Orrù. 1998 } & \text { Beachrock } & 8861 & 323 & -17.5 & 1.6 \\ \end{array}$

Table 2.

Driving mechanisms of Holocene coastal evolution of the Bonifacio Strait (Western

Mediterranean)

\author{
Matteo Vacchi ${ }^{1 *}$, Matthieu Ghilardi ${ }^{2}$, Paolo Stocchi ${ }^{3}$, Stefano Furlani ${ }^{4}$, Veronica Rossi ${ }^{5}$, Carla Buosi ${ }^{6}$, \\ Alessio Rovere $^{7}$ and Sandro De Muro ${ }^{6}$ \\ ${ }^{1}$ Dipartimento di Scienze Della Terra, Università di Pisa, Via S. Maı. 53, 56126, Pisa, Italy \\ ${ }^{2}$ CEREGE Aix Marseille University, CNRS UMR 7330, IRD, Collège de Fri nce, NRAE. Europôle de l'Arbois BP 80 \\ 13545 Aix-en-Provence CEDEX $0^{4}$ Fra ce. \\ ${ }^{3}$ NIOZ - Royal Netherlands Institute for Sea Research, Coastal Syst $\cdot$ ns (1 X), and Utrecht University, P.O. Box 59, \\ 1790 AB, Den Burg, Texel, Tı N, therlands \\ ${ }^{4}$ Dipartimento di Matematica e Geoscienze, L. iversity of Trieste, Italy \\ ${ }^{5}$ Dipartimento di Scienze Biologiche, Geologiche e Amb en a'i, Università di Bologna, Via Zamboni 6740126 , \\ Bolog a, Itaiy. \\ ${ }^{6}$ Dipartimento di Scienze Chimiche e Geologiche Coa tal and Marine Geomorphology Group (CM GG), Università \\ degli Studi di Cag . ri, 09042 Cagliari, Italy \\ ${ }^{7}$ University of Bremen. N`rum, ZMT, D-28359, Bremen, Germany
}

\title{
Abstract
}

We produced a new suite of sea-levrl ' ' ' ta which allowed assessing the Holocene evolution of the Bonifacio Strait, a key coastal sector of the $N_{i}$ 'diterranean Sea which experienced significant morphological changes since the Last Glacial Maximı m. i queezed between Corsica and Sardinia islands, this strait connects the two major basins of the western $\Lambda$ editerranean. Due to its peculiar geographic and morphological setting, the Bonifacio Strait is affected by extreme meteomarine conditions characterized by severe winds, waves, and currents.

The millennial sea-level changes were reconstructed through multiproxy investigations made of sediment coring and underwater beachrock sampling carried out on both sides of the strait. These data provided fresh insights into the timing of the progressive opening of the Bonifacio Strait which followed the Last Glacial Maximum when Corsica and Sardinia were connected forming the largest Mediterranean island. Major palaeogeographic changes occurred before $\sim 7 \mathrm{ka} \mathrm{BP}$. Since that period, the significant decrease of the northern ice-sheet melting triggered a significant sea-level stabilization which induced only minor 
modifications in the palaeogeography of the strait. In the late Holocene, the isostatic-related subsidence became the dominant factor controlling the sea-level changes which rose with rates $\leq 0.35 \mathrm{~mm} \mathrm{a}^{-1}$ in the last four millennia.

Our data have also an important archaeological implication because they indicate that the Bonifacio Strait has not represented a significant geographical barrier along the early Neolithic migration path which connected mainland Italy to northern Corsica and finally to Sardinia. This further confirms the ability of early Neolithic communities to navigate not also across large sea stretches but also maritime areas characterized by extremely complex meteomarine conditions.

\section{Introduction}

The Bonifacio Strait is a narrow coastal stretch connecting the two man basins of the western Mediterranean Sea and dividing the islands of Corsica and Sardinia, the third nq he second largest western Mediterranean Islands. At the end of the Last Glacial Maximum (LGM, 20 ^ ^), with sea level 120-140 m below present (e.g. Lambeck and Purcell, 2005), Corsica and Sardinia ve e connected, forming the largest Mediterranean island (with an area of about $47,000 \mathrm{~km}^{2}$ ) place 1 in he middle of the western part of the basin (Lambeck and Purcell, 2005). The progressive melting of : he northern hemisphere ice sheets produced a very rapid sealevel rise until $\sim 7.0 \mathrm{ka}$ ago (e.g. Peltier, $2^{\prime}$, :, Lambeck et al., 2014) which resulted in the progressive development of the Bonifacio Strait an the separation of Corsica and Sardinia. Conflicting sea-level data are presently available in the literature ('Tacchi et al., 2016; 2018) resulting in uncertainties regarding the timing and magnitude of this major pala 'ogeographic change. In particular, sea-level data from sediment cores performed in Sardinian coastal 'agoons (Di Rita and Melis, 2013; Melis et al., 2017; 2018) show a significant departure from a sea-level stand derived from some Neolithic archaeological data ( $7.3 \mathrm{ka}$ BP) found in a submerged cave in north-eastern Sardinia (Palombo et al., 2011; Benjamin et al., 2017).

This paper aims to provide novel field data on the Relative Sea Level (RSL) changes in this important Mediterranean sector, notably for the Holocene period (last $12.0 \mathrm{ka}$ BP). We thus produced a new geological sea-level dataset that was coupled with geophysical models and GIS analysis to provide new insights into the coastal landscape modifications triggered by the postglacial sea-level rise on both sides of the Bonifacio Strait. 
There is further archaeological interest in better constrain the palaeogeographical evolution of the Bonifacio Strait since it always represented the most rapid way to cross from Sardinia to Corsica. Archaeological evidence of human frequentation was recovered along both sides of the strait and dated from the Mesolithic to the Roman Times (e.g., Modi et al., 2017; Luglì̀ et al., 2018; Revelles et al., 2019). This narrow strait always represented a key crossroad not only for the crossing from Corsica to Sardinia but also for naval trading routes across the Western Mediterranean, notably linking the Spanish colonies to Rome (e.g., Medas, 2005; Opdebeeck, 2005; Reynolds, 2010). However, the extreme meteomarine conditions coupled with the complex geomorphology characterized by many emerging reefs have tlways made navigation in the strait very complex (e.g., Sorgente et al., 2012). This is not only testified ${ }^{1}, \mathrm{y}$ u $\mathrm{z}$, number of historical shipwrecks found in the area (Opdebeeck, 2005; Boetto 2012; Secci et al., 2( 13) 、 ut also by a large number of present-

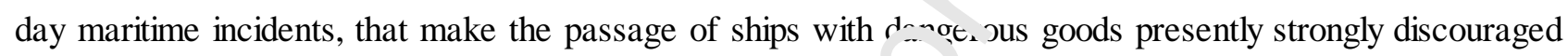
and subject to mandatory piloting (Sorgente et al., 2012).

\section{Study area}

Sardinia $\left(\sim 24,100 \mathrm{~km}^{2}\right)$ and Corsica $\left(\sim 8,640 \mathrm{kr}^{-}\right)$? $\cdot \mathrm{e}$ the second and the third-largest islands of the western Mediterranean (the largest being Sicily). Th Bonifacio Strait (hereafter BoS) separates the two islands with $\sim 80,000$ ha of sea, and hosts a large nur br $\mathrm{r}$-i small islands, islets and sea shoals (De Muro et al., 2010; Buosi et al., 2012, Fig. 1A). The geo'of.' of both northern Sardinia and southern Corsica is dominated by the Hercynian batholiths of Upper Carb niterous-Permian age characterized by different calco-alkaline granitic formations and fields of ba ic cikes (Oggiano et al., 2009). In northern Sardinia, the post-Hercynian formations are limited to Quat rnary deposits in the coastal areas and alluvial plains, except a very limited outcrop of Miocene limestone (Carmignani et al., 2016). Miocene marine sedimentary rocks outcrop in southern Corsica for a total surface area of $\sim 25 \mathrm{~km}^{2}$, notably around the town of Bonifacio (Tommasetti and Brandano, 2013). The coastal geomorphology of both sides of the BoS is strongly related to the dominant granitic nature of the substrate (De Muro et al., 2017) which resulted in several gently sloping rocky promontories alternated with river inlets often hosting brackish lagoons or salt-marshes. This peculiar riashape geomorphology is the result of the postglacial drawings of former river valleys (Soldati and Marchetti, 2017). The sole exception to the general granitic landscape is represented by scenic steep cliffs of Bonifacio 
which are carved in the Miocene rocks (Tommasetti and Brandano, 2013; Furlani et al., 2014). The tidal regime is microtidal and does not exceed $\pm 0.2 \mathrm{~m}$ (De Falco et al., 2011).

The BoS separates two distinct Mediterranean sub-basins, the Tyrrhenian Sea and the Algero-Provençal (see Fig. 1B). The strait, $\sim 11 \mathrm{~km}$ wide between mainland Corsica and Sardinia, hosts two main archipelagos Lavezzi (Corsica) and La Maddalena (Sardinia) which are composed by 10 main islands and $\sim 75$ small islets . In the central portion of the strait, the maximal depth of the seafloor is reduced to -70 $\mathrm{m}$ while in the eastern and western openings of BoS depths slowly decreases down to 90-100 m before approaching the continental slope, where strong bathymetric gradients occur (Cucco et al., 2012; Gé igny et al., 2015).

Due to its morphology, the BoS presents a very peculiar meteomarine seti. with a wind speed exceeding $16 \mathrm{~m} / \mathrm{s}$ ( 31 knots) for over $52 \%$ of eve ts (Cucco et al., 2012; Gérigny et al., 2015). This triggers high-intensity currents sometimes up to : $n_{\iota}^{\prime}$ (Gérigny et al., 2015). The main wind directions are the north-western Mistral and the south-west in $_{2}$ ibeccio, which are orographically controlled (De Falco et al., 2011). Western wind speed increare ov up to $20 \%$ due to the Venturi tunneling effect caused by the funnel shape of the strait (Cucc, et $11 ., 2012$ ). NW winds crossing the strait contribute to the generation of a wind-driven quasi-stable cy lonic gyre in the northern Tyrrhenian Sea that represents the most energetic mesoscale structure of this p rriun of western Mediterranean (Iacono et al., 2013, Olita et al., 2015).

\section{Methods}

\subsection{Facies analysis and sea leve' data from sediment cores}

Sediment cores carried out in $\mathrm{t}$ ansitional environments represent one of the major sources of Holocene sealevel data along the global coastlines (e.g., Khan et al., 2019). In this paper, we used sea-level data derived from six cores that were recently drilled in Piantarella (southern Corsica) and Budelli (a small island placed in La Maddalena archipelago, $\sim 8 \mathrm{~km}$ off the northern Sardinian coast) (Fig. 1C). Coring activity was carried out using a Cobra vibracorer with a hydraulic extraction system. All vertical measurements were undertaken using a DGPS (Differential Geographical Positioning System) and referred to the French geodetic datum (NGF) which is $0.12 \mathrm{~m}$ below the present mean sea level (msl, Morhange et al., 2013; Vacchi et al., 2016). The final vertical error associated with the coring activity is $\pm 0.05 \mathrm{~m}$. 
Besides the visual inspection of the cores, the reconstruction of the depositional environments was performed coupling grain size analysis with the quantitative determination of the faunal assemblages (i.e. molluscs and ostracods) found along the cored succession (e.g., Amorosi et al., 2014; Curras et al., 2016; Chelli et al., 2017).

For grain-size determinations, samples were taken at $5 \mathrm{~cm}$ intervals. Many displayed fine particles, with a general size below $200 \mu \mathrm{m}$ (e.g., Ghilardi et al., 2017). Organic matter was removed for laser-diffraction particle size study. The grain-size distribution was measured using a Beckman Coulter LS 13320 laser granulometer with a range of 0.04 to $2000 \mu \mathrm{m}$, in 132 fractions. The calculation model (software version 5.01) uses Fraunhöfer and Mie theory. For the calculation model, we $\mathrm{r}$ sea vater as the medium (RI $=1.33$ at $20^{\circ} \mathrm{C}$ ), a refractive index in the range of that of kaolinite for th soi 1 phase $(\mathrm{RI}=1.56$ ), and absorption coefficients of 0.15 for the 780 -nm laser wavelength and $0.2 \therefore$ i. e polarized wavelengths (Buurman et al., 1996). Samples containing fine particles were diluted, mer sur.o between 8 and $12 \%$ of obscuration and between 45 and 70\% PIDS (Polarization Intensity Diffe e $_{-}$nt 1 Scattering) obscuration. For what concerns the mollusc fauna, all samples were wet-sieved tror gh a $300 \mu \mathrm{m}$ wire mesh screen and air-dried at room temperature. The portion greater than $3 i^{n} \mu \mathrm{m}$ were examined under a binocular microscope and all identifiable shells and fragments were ( $\mathrm{l}^{\prime} \mathrm{e} \ldots \mathrm{d}$ and analyzed in separate plastic tubes (see details in Revelles et al., 2019). Identification of . nolluscan shells was subsequently assigned to assemblages according to the Péres and Picard (1964) an' réres (1982) classification system. In Piantarella lagoon, additional ostracod analyses, performed on 2 i samples collected from the reference core P1 and reported in Revelles et al. (2019), were used to su port refine the palaeoenvironmental interpretation and the changes in depositional environments along the studied successions (Marriner et al., 2012; Giaime et al., 2017; Rossi et al., 2017).

The results of the palaeoenvironmental reconstructions (see results section) revealed depositional facies associations typical for coastal lagoons, brackish swamps, and shallow-marine environments. All these facies can provide very useful insights into the sea-level evolution, notably in the Mediterranean context (e.g., Marco-Barba et al., 2013; Fontana et al., 2017; Brisset et al., 2018). Among them, lagoons and brackish swamps were widely used to produce relative Sea-Level Index Points (SLIP i.e. a point that constrains the 
palaeo RSL in time and space; e.g. Shennan et al., 2015) in Mediterranean sea-level studies (e.g., Fontana et al., 2017; Melis et al., 2017; 2018; Chelli et al., 2017; Brisset et al., 2018).

Following the protocol developed by Vacchi et al. $(2016,2018)$, we attributed the following indicative range (i.e. the relationship of the dated facies association with the contemporary msl) to the dated samples:

i) 0 to $-1 \mathrm{~m} \mathrm{msl}$ to samples collected from semi-enclosed/low-marine influenced lagoon deposits, characterized by the dominance of brackish-water molluscs and the euryhaline ostracod Cyprideis torosa, (Rossi et al, 2011; Salel et al., 2016; Chelli et al., 2017);

ii) 0 to $-2 \mathrm{~m}$ msl to samples formed under open/high-marine influenced 'dgoon conditions, with a high species diversity of the faunal assemblages comprising marine and bra :kis: molluscs, and a meiofauna dominated by brackish-marine species (Rossi et al., 2011; Marrine et a , 2014; Salel et al., 2016); iii) $\pm 0.5 \mathrm{~m}$ msl to samples from brackish swamp facies where ... ${ }^{\circ} \mathrm{c}_{\mathrm{l}}$ ) faunal and ostracod assemblages dominated by freshwater to slightly brackish taxa (e.g., Marrieı ‘t al., 2012; Giaime et al., 2017).

Mediterranean shallow marine facies associatior , (i.t. foreshore, shoreface) are generally characterized by fine to coarse sands deposited in the first few me " ${ }^{\text {s }}$ below msl. Mollusc and meiofauna assemblages mainly include infralittoral species (Amorosi et al., $\cap 11$, , and abundant Posidonia oceanica beds, a marine seagrass living down to $40 \mathrm{~m}$ depth (e.g., Mor.tinkune et al., 2016). Due to the difficulty in establishing a direct relationship with the former msl, w- used samples deposited within shallow-marine settings to produce Marine Limiting Points (MLP, i e.. r r jint that constrains the RSL above an elevation, Shennan et al., 2015).

\subsection{Petrographic analysis . nu vea-level data from beachrock samples}

Beachrocks are cemented coastal deposits that have often been used to assess Holocene shoreline migration and sea-level changes, notably in the Mediterranean Sea (e.g., Desruelles et al., 2009; Mauz et al., 2015; Karkani et al., 2017). The use of beachrocks as precise RSL indicators strongly dependent on the analysis of cement mineralogy and, if possible, of bedding morphology of a beachrock outcrop (e.g., Vacchi et al., 2012; Mauz et al, 2015). These analyses allow identifying the spatial relationship between the past shoreline and beachrock formation zone and thus the definition of the indicative meaning of the sample (Mauz et al., 2015). Along both sides of BoS, a significant number of beachrocks were studied since the '80s (e.g., Nesteroff, 1984; Ozer et al., 1984; De Muro and Orrù, 1998). Their depths range from few cms below the present msl to -70 m (De Muro, 1990) and their ages span the whole Holocene (Nesteroff., 1984; De Muro 
and Orrù, 1998). However, recent investigations (Vacchi et al., 2017, 2018) highlighted some significant problems in the ages yielded by some bulk cement samples collected in the BoS, notably in the samples younger than $7.0 \mathrm{ka} \mathrm{BP}$. This is particularly evident for the samples collected by Nesteroff (1984) which were likely rejuvenated by multiple cementation processes in the shallow water after the Mid Holocene RSL stabilization (e.g., last $~ 7.5 \mathrm{ka}$ BP, Vacchi et al., 2017).

For this reason, we carried out a new beachrock sampling campaign in Cala Lunga (Corsica, Fig. 1C) and Tanca Manna (Sardinia, Fig. 1C). Underwater surveys were carried out to record beachrocks features (depth below msl, width and, if present, sediment bedding and structure) and tr sample the beachrock slabs (Vacchi et al., 2012; Mauz et al, 2015; Karkani et al, 2017). Depth of the san, les was recorded by averaging 2 electronic depth gauges, with an accuracy $\pm 0.5 \mathrm{~m}$ (Rovere et al. 201); Vacchi et al., 2012). Thin sections were cut to perform petrographic (polarizing microscor-) and microstratigraphic analyses. These observations allowed the characterization of the constituents the nresence of bioclasts as well as the type of cement. These analyses are required to produce $r o^{\prime}$.1d red precise RSL index points from beachrock samples (e.g., Desruelles et al., 2009; Mauz et d., _015). In the intertidal zone, the metastable aragonite and High Magnesium Calcite (HMC) form as irregularly distributed needles, isopachous fibers or rims, and micritic cement (Desruelles et al., 2009) 5 al .ples having these characteristics have an indicative range encompassing the whole tidal range ( $\eta_{1}$ ' 'n high water to mean low water), thus $\pm 0.20 \mathrm{~m}$ (Porto Torres Tidal Station, www.mareografico.it).

\subsection{Chrono-stratigraphy}

The age of the samples was zstablished by a series of new 19 AMS ${ }^{14} \mathrm{C}$ radiocarbon dates taken from marine/lagoonal shell, organic sediments as well as from remains of the Mediterranean seagrass Posidonia oceanica (Table 1). Because the production of atmospheric radiocarbon has varied through geological time, radiocarbon ages were calibrated to provide dates in sidereal years with a $2 \sigma$ range. All samples were calibrated using CALIB 7.0. We used a laboratory multiplier of 1 with $95 \%$ confidence limits and employed the IntCal13 and Marine13 (Reimer et al., 2013) datasets for terrestrial samples and marine samples (averaged $\Delta \mathrm{R}$ for the region is $27 \pm 32$, Reimer et al., 2004), respectively.

\subsection{Relative Sea-Level and palaeogeographic reconstructions}

For each dated sample, SLIPs were produced using the following equation: 
$\operatorname{SLIP}_{\mathrm{i}}=\mathrm{A}_{\mathrm{i}}-\mathrm{I}_{\mathrm{i}}$

(Shennan and Horton, 2002; Shennan et al., 2015), where $A_{i}$ is the altitude and $I_{i}$ is the midpoint of the indicative range (the reference water level) of sample i, both expressed relative to the same datum, msl in our analysis.

The total vertical error is obtained by adding in quadrature individual errors according to Shennan and Horton, (2002). These errors represent the sources of error for each SLIPs including the indicative range. MLPs are also subjected to these errors, except for the indicative range which does not apply for these kinds of sea-level data (Hijma et al., 2015; Khan et al., 2019).

We used the newly assembled RSL record to attempt the reconstru :tio of the Holocene palaeo-coastline evolution of BoS based on the high-resolution modern bathym try EMODnet Bathymetry Consortium, Thierry et al., 2019). The bathymetric data were imported ar: rruessed in a GIS environment (QGIS 3.10 software). We remark that caution should be adopted in s'ch 'ind of palaeogeographical reconstructions, especially in those sites that were most likely affecte $l_{l} \cdot m_{\text {jjor }}$ progradation processes. However, this is not the case of the BoS which is mostly charac eriz' $\mathrm{d}$ by rocky coastlines and coastal plains with a limited extent.

\subsection{Predictions of Relative Sea-Level}

We compared the newly assembled su ${ }^{\circ}$ e of SLIPs and MLPs with four different geophysical Glacio-hydro isostatic adjustment (GIA) models w: ich predict the RSL evolution in this portion of the Mediterranean Sea. Geological data are strongly eea $d$ to both constrain these models and to test the accuracy of predictions made using them (e.g., Stocch and Spada, 2007; Lambeck et al., 2011; Peltier et al., 2015). In particular, by comparing RSL data to GIA predictions in the Mediterranean Sea, it is possible to infer parameters relating to the rate and geographic source of meltwater influx (e.g. Stocchi et al, 2005; 2018; Vacchi et al., 2018) and the rheological structure of the solid Earth (e.g. Stocchi and Spada, 2009; Lambeck et al., 2011; Roy and Peltier, 2018).

We obtained the RSL model predictions for the BoS by solving the Sea Level Equation (SLE) according to the pseudo-spectral method (Spada and Stocchi, 2007). We compared three different ice-sheet chronologies that describe the melting of the Last Glacial Maximum ice-sheets up to the present: ICE-5G (Peltier, 2004), ICE-6G (Peltier et al., 2015) and ANICE-SELEN (De Boer et al., 2014). The SLE was solved for a spherical, 
self-gravitating, rotating, and deformable Earth model that is characterized by a $100 \mathrm{~km}$ thick elastic lithosphere, a three-layer Maxwell viscoelastic mantle, and an inviscid core. Each of the three computations allowed to predict a nominal RSL curve, based on a three-layer approximation of the multi-layered viscosity profile VM2 characterized by upper mantle and transition zone viscosity of $0.5 \times 10^{21} \mathrm{~Pa}$ s and lower mantle viscosity of $5 \times 10^{21} \mathrm{~Pa} \mathrm{~s}$ (Peltier, 2004; Stocchi et al., 2018). We further compared our data with the RSL prediction for the BoS released by Lambeck et al., (2011) using the K33_j1b_WS9_6 geophysical model (hereafter K33). The rheological parameters adopted for this computation correspond to the three-layer model with an effective elastic lithospheric thickness of $65 \mathrm{~km}$, an up er mantle viscosity of $3 \times 10^{20} \mathrm{~Pa} \mathrm{~s}$ and a lower mantle viscosity of $3 \times 10^{22} \mathrm{~Pa}$ s (Lambeck et al., 2011).

\section{Results}

\subsection{Depositional facies of Piantarella and Budelli cores}

Piantarella cores reached the maximal depth of $\sim 6.5$ below the 'urface. They were performed on the border of the lagoon at elevations ranging from 0.24 to $0.0^{7}$, at jve the msl (Fig. 2A). In Piantarella 1, the core reached the granitic substrate. In Budelli, the $\mathrm{c}$ res did not exceed $1 \mathrm{~m}$ below the surface and all reached the granitic basement. They were performed i- a brackish swamp developing in a backshore depression at elevations ranging from -0.25 to $-0.5 \mathrm{~m} \mathrm{~m}$ !

The multiproxy analysis of sedimentni ?V and faunal assemblages revealed facies typical of Mediterranean coastal lagoons (Unit L1 and L2), washover fan (W), brackish swamp (Unit BS), and shallow marine environments (Unit M1 and M2). The detailed description of the grain sizes and faunal assemblages of Budelli cores is provided in Ap endix 1, while those for the Piantarella cores are reported in Revelles et al., (2019).

\section{Brackish swamp facies (Unit BS)}

This depositional facies was found both in the uppermost part of Piantarella and in Budelli cores. Unit BS is made of greyish silty clays with moderate organic matter content (up to $\sim 30 \%$ ). Macrofaunal shells are absent, while ostracods are largely represented by Cyprideis torosa (ca. 77\%) an opportunistic, truly euryhaline species able to thrive from almost freshwater to hypersaline conditions irrespective of the substratum features (Athersuch et al., 1989; Meisch, 2000). C. torosa is accompanied by remarkable percentages of freshwater - low brackish taxa as Heterocypris salina (ca. 17\%; Henderson, 1990) and very 
low percentages of brackish and euhaline taxa (e.g. Loxoconcha species and Aurila arborescens <2\%). Sporadic evidence of Posidonia oceanica layers was also observed in Budelli. This unit corresponds to the modern brackish swamp environment that can be observed both in Piantarella and in Budelli. The age of BS facies ranges from $\sim 3.4$ to $\sim 0.3 \mathrm{ka} \mathrm{BP}$ in Budelli and from $\sim 0.8$ to $\sim 0.3 \mathrm{ka}$ BP in Piantarella (Table 1).

Lagoonal facies (L1 and L2)

Unit L1 is made of dark clays characterized by organic matter percentages that do not exceed $18 \%$. Abundant plant remains and large wood fragments were found embedded within the organic clays. The macrofaunal assemblages show a very low diversity being dominated $\mathrm{t} v$ the lagoonal bivalve Cerastoderma glaucum often found in living position (articulated valves). No ostracr a it.' ormation was available. However, the very low diversity of species and the sedimentology of this aye are consistent with a semi-enclosed lagoon environment. This facies develops from $\sim 6.7$ to $\sim 5.5 \ldots\llcorner$ D the bottom of P3 core while it was dated at $\sim 4.6 \mathrm{ka} \mathrm{BP}$ in P2 core (Fig. 2, Table 1).

Unit L2 is characterized by coarse sands alternated $w \mathrm{~h}^{-} \mathrm{cl} \cdot \mathrm{y}$, which contain intact specimens of marine and lagoonal molluscs such as Loripes lacteus, Cer thir $m$ sp., Bittium reticulatum and C. glaucum. Presence of P. oceanica layers was also observed. The nstracod fauna is dominated by the euryhaline species C. torosa (ranging between ca. 65-85\%), mainly cro o. panied by brackish and brackish-euhaline taxa preferring vegetated substrates as Loxoconcha elliptica (ca. 2-8.5\%), Loxoconcha stellifera (ca. 6-13\%) and Xestoleberis communis $(<5 \%)$. Lov, percentages of coastal-shallow marine species as Loxoconcha gr. $L$. exagona $(<7 \%)$ and Aurila a rbor sscens $(<5 \%)$ also occur. Sedimentological features and the highly diverse fossil content, characterized by a mixed brackish-shallow marine fauna, indicate that this unit was formed in an open lagoonal environment with significant marine influence. This facies association was only found in P1 core and its upper part was dated at $\sim 4.3 \mathrm{ka} \mathrm{BP}$ (Fig. 2).

Marine facies (Unit M1 and M2)

Unit M1 is made of grey fine sands mixed with clays and rich in P. oceanica remains. The macrofaunal assemblage is dominated by large specimens of C. glaucum. The ostracod fauna is mainly represented by epiphytic taxa able to tolerate a wide range of salinity conditions as L. elliptica (ca. 17-41\%), L. stellifera (ca. 13-19.5\%) and Xestoleberis species (ca. 13-39\%), with the remarkable occurrence (ca. 20-32\%) of shallow marine-coastal species (as A. arborescens, Loxoconcha gr. L. exagona and Palmoconcha turbida). 
Interestingly, the euryhaline species $C$. torosa occurs although with low percentages (ca. 2.5-11.5\%). Both sedimentology and the faunal assemblages of this unit are consistent with a semi-protected environment characterized by a dense seagrass cover at the bottom and salinity conditions oscillating around the marine values as a coastal bay/embayment. This facies was found at the bottom of core P1 ( 7.4 to $\sim 7.1 \mathrm{ka} \mathrm{BP})$ and in the mid-upper part of core P3 (no dates, Fig. 2).

The M2 Unit is characterized by fine to coarse grey sands with the abundant presence of $P$. oceanica. It was found both in Piantarella (P1 and P2) and in all the Budelli cores. The macrofaunal assemblages are dominated by the infralittoral gastropods B. reticulatum, Rissoa ventr cosa, Nassarius reticulatus and by shallow marine to lagoonal bivalve species mainly represented by C. lan 'um and L. lacteus. In Budelli, the bivalve species were mainly characterized by R. ventricosa, B. rı ticuı atum and Abra sp. In Piantarella, this Unit also contains few valves of poorly-preserved brackic.. an ${ }^{\mathrm{J}}$ brackish-euhaline ostracods at places

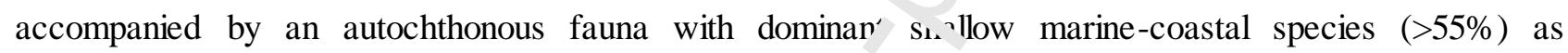
Loxoconcha gr. L. exagona, A. arborescens, Pon yt ıere turbida and Palmoconcha turbida. The sedimentology and the faunal assemblages sug',est Unit M2 deposited in a foreshore to shoreface environment that was less protected and likt:y less embayed than the M1 one. This is further corroborated by the presence of in-situ fossil matte of P. o e in $; a$ at the bottom of the B1 core, which is a clear indication of a marine environment at $\sim 2.7 \mathrm{ka} \mathrm{BP}$. $i$. is unit was also found at the bottom of B2 core $(\sim 3.7 \mathrm{ka} \mathrm{BP})$ and the bottom of $\mathrm{P} 2$ core ( 4.6 ka BP, $\mathrm{Fl}_{\mathrm{s}}$ 2). No dating was available for the M2 Unit occurring in P1 and B3 cores.

\section{Beach barrier/washover fan de osit (W)}

This Unit is characterized by medium to coarse sand layers with remains of P. oceanica. It was observed in P1 core and in B1 and B2 cores (Fig. 2) where sands show evidence of oxidation. Shells are always very fragmented and hard to recognize, while ostracods are absent. The interpretation of the depositional facies of this Unit is very complex, however, the sedimentological features and the stratigraphic position suggest a high-energy, coastal environment subject to overwash processes such as a washover fan. Due to the lack of datable materials, no ages are available for this Unit both in Piantarella and Budelli.

4.2. Beachrocks morphology and microstratigraphy 
Underwater surveys performed in Tanca Manna (Sardinia) and Cala Lunga (Corsica) revealed the presence of multiple beachrock outcrops occurring nearly parallel to the present coastlines (Fig. 3A,B). In Tanca Manna (Fig. 3A), a shallow beachrock develops from -0.8 to $-1.2 \mathrm{~m}$ msl (Fig. 3C) while a deeper outcrop occurs between -3.5 m and -3.9 m msl (Fig. 3D). In Cala Lunga (Fig. 3B), a shallower beachrock develops from -0.3 to $-0.6 \mathrm{~m}$ msl (Fig. 3E) while the deeper one was found between -3.4 and $-3.8 \mathrm{~m}$ msl (Fig. 3F). Microscope observations indicated grain sizes ranging from fine to medium sands even if internal sediments of smaller size were observed between grains (Fig. 3G). We further observed the presence of bioclasts, often showing a very high degree of preservation notably in the deepest outcr sps of Tanca Manna (Fig. 3H) and in Cala Lunga (Fig. 3K). The bounding materials observed betwe en rains and bioclasts are mainly characterized by early intertidal and poloidal cements. The sbse ved early intertidal cements were characterized by small bladed isopachous fringe of limpid ... c ontiguous HMC crystals (Fig. 3G,H) or characterized by micritic texture (irregularly shaped and of nicrobial origin) followed by radial fibrous HMC calcite (Fig. 3J). Peloidal cements are made of 1 “ ri $^{\prime}$ e partially replaced by coalescent pellet clusters. These pellets are agglomerates of particles tha col $\mathrm{d}$ form during the diagenesis inside the pore space within the intertidal zone (Fig. 3J,K).

Microscope analysis identified that cemen $t^{\mathrm{l}}$ ic . for radiocarbon dating was extre $\eta_{\mathrm{N}} \mathrm{l}_{\mathrm{V}}$ difficult. Moreover, the presence of micritic fillings, often recrystallized, could affect the raa sarbon dating producing apparently older dates. However, the high degree of conservation of the oioc. ssts in the beachrock of both Tanca Manna and Cala Lunga, allowed us to attempt two radiometric dating on Tellinidae and Conidae shells. We selected two samples that most likely experienced little reworking processes having the shell a high degree of preservation. It implies a very short permanence of the dead bioclast on the beach before the fossilization within the beachrock formation. For this reason, we assumed that the bioclast age can reasonably correspond to the age of the whole beachrock body. This assumption seems to be confirmed by the dating yielding two very coherent uncalibrated radiocarbon ages of $6050 \pm 30 \mathrm{BP}$ and $5920 \pm 30 \mathrm{BP}$ (Table 1, Fig. 3A,B).

\subsection{RSL reconstructions}

Our new radiocarbon dataset provides novel insights on the RSL evolution in the BoS (Fig. 4). We produced a new suite of SLIPs (11 from the cores and 2 beachrocks), and 6 MLPs (Table 1). These data were coupled 
with the other beachrocks (2 SLIPs) and sedimentary data (2 SLIPs and 2 MLPs) already available for the BoS (Table 2). The oldest data (beachrocks) indicate that RSL rose from $29.5 \pm 1.6 \mathrm{~m}$ at $\sim 9.8 \mathrm{ka}$ BP to 17.5 $\pm 1.6 \mathrm{~m}$ at $\sim 8.8 \mathrm{ka}$ BP. Younger MLP document the progressive rise of RSL that was at or slightly above -6.0 and $-4.9 \mathrm{~m}$ msl at $\sim 7.4$ and $\sim 7.2 \mathrm{ka}$ BP respectively.

Between $\sim 6.4$ to $\sim 6.3 \mathrm{ka} \mathrm{BP}$, the beachrocks of Tanca Manna and Cala Lunga beachrocks place the RSL between $-3.8 \pm 0.5$ and $3.7 \pm 0.5 \mathrm{~m}$ msl, respectively. This is in very good agreement with the SLIPs derived from Piantarella cores which document a RSL from $-3.3 \pm 0.6 \mathrm{~m}$ msl at $\sim 6.6 \mathrm{ka}$ BP to $-3.0 \pm 0.6 \mathrm{~m}$ at $\sim 6.3$ ka BP and subsequently to $-2.1 \pm 0.5$ at $\sim 5.5 \mathrm{ka}$. Between $\sim 4.6$ and $\sim 4.3 \mathrm{ka}$ BP a composite RSL made of two MLPs and three SLIPs indicate RSL was likely placed between -1.2 tha $1.6 \mathrm{~m} \mathrm{msl}$ in good agreement with the coeval MLPs. RSL rose to $-0.8 \pm 1.0$ at $\sim 3.6 \mathrm{ka}$ BP while SL Ps 1 dicate that the total RSL variation did not exceed $1.1 \mathrm{~m}$ msl in the last $2.4 \mathrm{ka} \mathrm{BP}$.

\section{Discussion}

\subsection{Drivers of RSL changes in the Bonifacio Strait}

The interplay between eustatic, GIA and tecto ic $c$ smponents largely controlled the variability of postglacial RSL changes along the global coasts (e.g., : ' han et al., 2015). In the Mediterranean Sea, crustal movements triggered by Holocene activity of major fa $\mathrm{ll}^{+}, \ldots \mathrm{d}$ /or volcanic activity often significantly influenced the RSL evolution (e.g., Pirazzoli, 2005; Morba. re ex al., 2006; Vacchi et al., 2019). This has often complicated the identification of the GIA component in the RSL record, which constitutes an important driver of past, present and future sea-level variabilit ' (e. r. Milne et al., 2009; Khan et al., 2015, 2019). This issue is even more complex in those coastal regiols located at the mouth of major Mediterranean rivers, for instance the Ebro, (Somoza et al., 1998), the Nile (Marriner et al., 2012) or the Po (Bruno et al., 2020), where the RSL records were strongly affected by long-term subsidence (with rates up to $\sim 3 \mathrm{~mm} \mathrm{a}^{-1}$ ) induced by sediment loading and compaction.

In this context, the newly produced Holocene RSL geological record in the BoS is of particular interest because:

iii) the Sardinia-Corsica block is considered one of the most tectonically stable Mediterranean areas (e.g., Nocquet, 2012; Faccenna et al., 2014) 
iv) most of the sedimentary datapoints were made of basal samples (i.e., samples recovered from sedimentary units overlying incompressible substrates, rocky basements, or a thick layer of coarse sand or gravel) and are therefore less prone to compaction (Hijma et al., 2015). Also, beachrock samples are considered virtually incompressible samples (Mauz et al., 2015).

The RSL record extends the last $\sim 10.0 \mathrm{ka}$ and is particularly robust in the last $6.5 \mathrm{ka} \mathrm{BP}$. In the Early Holocene period, the two beachrock samples indicate RSL rose with rates of $12.6 \pm 3.3 \mathrm{~mm} \mathrm{a}^{-1}$ between $\sim 9.8$ and $\sim 8.8 \mathrm{ka}$ BP. These rates, mainly controlled by the eustatic deglacial signal, are consistent (within error bars) with the near-uniform global sea-level rise at average rates of $\sim 15 \mathrm{~mm} \mathrm{a}^{-1}$ between $\sim 11$ and $\sim 8.2 \mathrm{ka}$ BP (Lambeck et al, 2014). Between $\sim 8.2$ and $\sim 6.7 \mathrm{ka} \mathrm{BP,} \mathrm{the} \mathrm{final} \mathrm{nas} \mathrm{of} \mathrm{North} \mathrm{American} \mathrm{deglaciation}$ (Peltier, 2004; Lambeck et al., 2014) and the consequent reduc tion of the meltwater input resulted in a significant deceleration of the global sea-level rise (Peltier, 2 n1). This is recorded by the BoS RSL record which shows a very sudden slow after $\sim 7.4 \mathrm{ka}$ BP. Since th $\mathrm{t}$ p $\mathrm{c}$ iod, the entire RSL variation did not exceed -6.1 m msl, in agreement with the data reported both :- of ter coastal plains in Sardinia (Di Rita and Melis, 2013; Melis et al., 2017; 2018) and in southern fus :any (mainland Italy, facing southern Corsica, D’Orefice et al., 2020). On the contrary, this RSL $t$ ' nlution pattern conflicts with the archaeological data from the submerged portion of the Grotta Verd a.e (northwestern Sardinia, Benjamin et al., 2017) whose exploration dates back to the 1970^ To Schiavo 1987; Guillot, 1991). Here, evidence of pottery from Cardial period ( 7.3 ka BP) found at $-10 \mathrm{~m}$ msl was used to reconstruct a RSL placed at $\sim 11 \mathrm{~m}$ (Palombo et al., 2017; Benjamin et al., 2(17), that is 4 to $5 \mathrm{~m}$ below the coeval RSL position derived from the cores performed in the surrounding c astal plains (see Vacchi et al., 2018 for a detailed discussion of these data). Guillot (1997) reported considerable debris flow along the flank of the cave and several ceramic fragments were found mixed within this debris down to $\sim-22 \mathrm{~m}$. This may be an explanation for this misfit but only by new high-resolution mapping of the submerged cave and/or by new sediment cores that should be performed in the coastal plains adjacent to the cave would provide robust evidence to solve this intriguing issue.

Of particular interest is the RSL evolution since $7.0 \mathrm{ka}$. In this period, a global progressive decrease in the rising rates was documented (Peltier, 2004; Lambeck et al., 2014) with the GIA-related deformation that becomes the main factor controlling the RSL changes. 
In the Mediterranean, the predicted GIA-driven land-level changes are controlled by the interplay between ice and water loading. The former is directly influenced by the spatiotemporal variations of shape and size of the nearest ice sheets (Eurasia but also North America) and, accordingly, by the upper portion of the Earth's mantle. The latter mostly depends on the volumetric variation of the ice sheets (glacioeustatic water loading) and, because of the size of the Mediterranean basin, on the lower portion of the mantle (Lambeck and Purcell, 2005; Stocchi and Spada, 2009). Overall, the effects of the nearest ice sheet (Fennoscandia) tend to be dependent on the latitude, while those of the North American ice sheets have a longitudinal pattern across the Mediterranean basin (Lambeck and Purcell, 2005; Stocchi and Sp da, 2009; Stocchi and Spada, 2005). Instead, the water loading term results in widespread subsidence that eac: the maximum in the bulk of basin (Lambeck and Purcell, 2005; Stocchi and Spada, 2009; Roy and I eltie , 2018) and that is also compensated by uplift along the continental margins (Stocchi et al., 2018).

The new dataset provides insights into the magnitude of this contribution in the center of the western Mediterranean basin. In particular, the presence of ra sal samples of beachrocks and lagoonal samples at $\sim 6.5 \mathrm{ka}$ BP robustly indicated that the maxima' $\mathrm{RS}$, variation was $\sim 3.5 \mathrm{~m}$. This implies average rising rates by $\sim 0.5 \mathrm{~mm} \mathrm{a}^{-1}$ in a period where the $\mathrm{RS}_{i}$ variation is majorly controlled by the isostatic contribution. A further refinement of the magnitude of th 2 in : signal is provided by the Late Holocene record where the eustatic contribution is negligible due to the absence of global ice melt since $\sim 4.0 \mathrm{ka}$ (Peltier, 2004; Milne et al., 2005; Engelhart et al., 2015). Ou dataset indicates that the maximal GIA-related subsidence in the BoS did not exceed $0.35 \mathrm{~mm} \mathrm{a}^{-1}$. 'his ralue is of particular interest because GIA still contributes significantly to both modern and future sea-leı 2 l change. Vacchi et al. (2018) highlighted the lack of Late Holocene robust data to quantify the GIA-related vertical motions, notably in northern Sardinia. The improved dataset from the BoS represents thus a significant advancement in the definition of the components which concur to the on-going RSL rise in this sector of the Mediterranean basin.

\subsection{Implications for GIA modeling in the western Mediterranean}

The newly assembled record constitutes a crucial benchmark to evaluate the predictive potential of a variety of GIA models in the western Mediterranean Sea. As stated in section 5.1, in the BoS record the RSL evolution is minimally influenced by tectonics and compaction related subsidence. Furthermore, southern Corsica and northern Sardinia coasts lie in the center of the western Mediterranean basin, where all GIA 
models predict a maximum hydro-isostatic contribution (e.g., Lambeck and Purcell, 2005; Stocchi and Spada, 2009; Roy and Peltier, 2018).

The comparison between the new RSL dataset and the four geophysical predictions shows variability in the fit/misfit pattern along the Holocene period. In the Early Holocene (8.0 to $12.0 \mathrm{ka} \mathrm{BP}$ ), we observed a general misfit between models and data. The RSL position is significantly overestimated by ICE-5G, ICE6G, and ANICE models. This overestimation is larger than $\sim 5 \mathrm{~m}$ at $\sim 8.8 \mathrm{ka} \mathrm{BP}$ and larger than $\sim 7 \mathrm{~m}$ at $\sim 9.8$ ka BP. Conversely, K33 significantly underestimates RSL: the predicted RSL is $\sim 15 \mathrm{~m}$ below the SLIP at $\sim 9.8 \mathrm{ka} \mathrm{BP}$ and $\sim 10 \mathrm{~m}$ below the SLIP at $\sim 8.8 \mathrm{ka} \mathrm{BP}$. In the Mid to Li te Holocene period (last $\sim 8.0 \mathrm{ka} \mathrm{BP}$ ) our dataset is based on a robust number of SLIPs (14) corroborated jy ; additional MLPs (Table 1 and 2). These data indicate that RSL was already at or above $-6 \mathrm{~m}$ at 7.4 a BP, showing discrepancy with the coeval predictions of ICE-5G, ANICE, and K33 which $u^{2}$ 'ne timate the RSL position (Fig. 4). This underestimation is within $\sim 0.5$ and $\sim 1 \mathrm{~m}$ for ANICE and IC $2-\supset \sim$ respectively while the misfit increases up to $\sim 5 \mathrm{~m}$ for K33. Conversely, the ICE-6G model is : gr od agreement with the data for the entire Mid Holocene period.

The misfit between SLIPs and models decr' ^ses in the remaining part of the Holocene. In fact, we observed a good fit of ICE-5G, ICE-6G, and ANIC $₹$ os he entire Late Holocene period ( $~ 4$ to $\sim 0 \mathrm{ka} \mathrm{BP}$ ) while K33 can reconcile the data only in the last $\sim 3 \mathrm{ka}$ (Fig. 4).

The expanded dataset from the Bos - onfirms the good prediction potential of ICE-6G model for the western Mediterranean area, at least $\mathrm{n}$ th Mid to Late Holocene period (Fig. 4). Conversely, for ICE-5G, ANICE and K33 we observed a varia le overestimation of the hydro-isostatic component which become the major driver of RSL changes after the significant decrease of meltwater-equivalent input after $\sim 7 \mathrm{ka}$ BP (Lambeck et al., 2014).

The matter is different if we consider the Early Holocene record (Fig. 4). In this timespan, none of the models can reconcile the RSL evolution as already noticed in other portions of the western Mediterranean Sea (Brisset et al., 2018; Melis et al., 2018; Vacchi et al., 2018). We speculate that this might depend on the ice-sheets models (shapes and sizes) as well as on the solid Earth parameters and stratification. However, further data are required to corroborate the Early Holocene record that is presently only composed by two beachrocks sampled and dated more than 20 years ago (Nesteroff, 1984; Demuro and Orrù, 1998). 
However, we remind that all the GIA models currently employed to predict RSL in the Mediterranean Sea do not consider the lateral variations in mantle viscosity or the thickness of the lithosphere (Melini and Spada, 2019). This represents a limitation because it is known that these parameters may significantly affect the Earth's response to deglaciation (Spada et al., 2006).

5.3. Palaeogeographic evolution of the Bonifacio Strait and influence on the early colonization of the Islands The palaeogeographic reconstructions of the former shorelines have a great geoarchaeological interest because coasts have always played an important role as places of natural landing and cultural exchange (Di Rita and Melis, 2012). In the Mediterranean, the identification of fc mer land bridges is fundamental to understand the migration patterns, notably between the mainland a d lie islands (e.g., Shackleton et al., 1984, Van Andel, 1989, Antonioli et al., 2014; Dawson, 2016). Fu ther nore, the Mediterranean islands have been recognized as key regions to study the man-environme an interactions (e.g., Ammerman and Davis, 2013; Ghilardi and Lespez, 2017). This is mainly becar se they are highly sensitive to climatic and anthropogenic factors (being isolated areas with low "e rer se, e.g., Fitzhugh and Hunt, 1997; Médail, 2017; Revelles et al., 2019).

The newly assembled RSL record allows $u_{s}$ to tentatively reconstruct the shoreline position in the BoS in the last $\sim 10.0 \mathrm{ka}$ BP. At this period (Fig. 5A, ' $\mathrm{nt}$ BoS was already formed but its width was smaller than the present one ( $\sim 5$ vs $\sim 11 \mathrm{~km})$. Lavezzi , nd Cavallo Islands were still connected to mainland Corsica while a small archipelago was outcropping in correspondence of the Sperduti banks (Fig. 5A). The Maddalena archipelago was already an nsu $r$ complex even if its morphology was significantly different from the present one. Maddalena, Capre a, and Santo Stefano islands were forming a macro-island placed very close to mainland Sardinia ( $\sim 500 \mathrm{~m}$ in the closest point). Northwards, Budelli, Razzoli, and Santa Maria were merged into a single island, together with the Barrettini banks (Fig. 5A). In the northwestern and southeastern portions of the strait, small archipelagos were forming in correspondence of the Moines and Bisce banks.

At $\sim 9$ ka BP (Fig. 5B), we observed a palaeogeography quite similar to the previous one except for the significant submersion of a large portion of the Moines, Berrettini, Sperduti and Bisce banks. Between $\sim 10$ and $\sim 8 \mathrm{ka}$ BP, human presence in Sardinia and Corsica was still very scarce, and limited to individual burial in southern Corsica and some dislocated bones in central-eastern Sardinia (Luglié, 2018). The human 
migration from mainland to both islands was largely influenced by the permanent insularity condition which Corsica and Sardinia maintained even during the sea-level low-stand at LGM (see Fig. 1A, Modi et al., 2017; Luglié, 2018). Archaeological evidence suggests only sporadic and discontinuous frequentation during Palaeolithic and Mesolithic ages mainly characterized by ephemeral phenomena of seafaring (e.g., Modi et al., 2017; Cherry and Leppard, 2018; Lugliè, 2018). Both archaeological and genetic data indicate the presence of these discontinuous settlements until the transition between Mesolithic and Neolithic ( $\sim 8.2 \mathrm{ka}$ BP) followed by a simultaneous beginning of the permanent colonization of both islands at $\sim 7.7$ to $\sim 7.5 \mathrm{ka}$ BP (Luglié, 2018; Tamm et al, 2019). Since that period, our data sho that the BoS palaeogeography was very similar to the present morphology of the strait (Fig. 5B) with a $\mathrm{I}_{\mathrm{L}}$. $\mathrm{x}$ ximal RSL variation that did not exceed $6.1 \mathrm{~m}$ in the last $7.4 \mathrm{ka}$ BP. The neolithization of Sar inia vas associated with the arrival of a genetically-distinct group of immigrants from mainland $F_{-n}$ na This migration path likely connected mainland Italy with northern Corsica via the Tuscan archipe age and finally to Sardinia through the crossing of the BoS (Vigne, 1992, Fig.1A). According to our r $^{\mathrm{A}_{1}}$ : os zographical reconstruction, crossing the strait for the early Neolithic humans would have require , na igation of a minimum of $\sim 6 \mathrm{~km}$ in a meteomarine setting comparable to the present one since the cir - ilation in the BoS is mainly forced by its morphological pattern (see section 2.1, Gérigny et al., 2011, Cuc $`$ e dl., 2012; Olita et al., 2015). This seems to support the theory of good navigation skills of the early 1'eolitnic population (Dawson, 2011; 2016; Lo Presti et al., 2019). In fact, they were not only able to cros the wide stretches of sea ( 25 to $\sim 30 \mathrm{~km})$ which separated Elba and Capraia Islands from northe $\mathrm{n}$ C rsica (Fig. 1A) but also complex maritime sectors, such as the BoS, characterized by extreme cona ions of wind, waves, and currents (Gérigny et al. 2015). More generally, our data indicate that the BoS did not represent a significant geographical barrier. In fact, the two islands have shared comparable demographic histories as indicated by the similarities in the archaeological record since the Neolithic period (Lugliè, 2017; Tamm et al., 2019).

\section{Conclusions}

The multiproxy investigation carried out on both sides of the Bonifacio Strait (southern Corsica-northern Sardinia) allows reconstructing $10 \mathrm{ka}$ of RSL changes. The postglacial sea-level rise triggered the progressive development of this crucial sea stretch that presently connects the two major basins of the Western Mediterranean. 
Our data are of particular interest because they are collected in one of the most tectonically stable areas of the Mediterranean and because minimally affected by compaction-related subsidence. The reconstructed sealevel evolution is thus only influenced by the interplay between eustatic and hydro-isostatic components. Our data indicate that GIA contribution in this portion of the Western Mediterranean did not exceed $0.35 \mathrm{~mm} \mathrm{a}^{-1}$. GIA signal contributes to present-day and future sea-level change and this value should be considered in the computation of future scenarios of sea-level rise of both Corsica and Sardinia.

The comparison between our data and available GIA models indicated that ICE-6G (VM2) model has proved to be the most appropriate to predict the Mid to Late Holocene 2SL changes in this sector of the Mediterranean. Conversely, we observed a significant misfit of all the avc ilable GIA models and the data in Early Holocene.

The palaeogeographic reconstruction indicates that the $=\pi_{1}{ }^{\circ}$ acio Strait did not show significant morphological modifications since the RSL stabilization wfich rccurred $\sim 7 \mathrm{ka}$ BP. Since that period, we only observed minimal modifications in the geography of he several insular complexes and archipelagos which occur in the strait. Finally, our data con irm the good navigation ability of the early Neolithic populations which were able to cross one $\omega_{2}$ the most complex sectors still now notorious among sailors for its extreme meteomarine setting.

From a GIA perspective, the regiona 1 attern that arises from the novel dataset suggests that the available GIA models should be revised in -rder to reduce the excess of subsidence on the bulk of the west Mediterranean basin. This im lies modifications of bot ice-sheets and 1D earth models. We do not rule out that a 3D non-linear rheology $\mathrm{n}$ ight reconcile predictions and observations.

\section{Acknowledgments}

We warmly thank Dr Yuri Donno of the Parco Nazionale Arcipelago della Maddalena and Alessandro Porqueddu for the support during the fieldwork in Budelli Island. Part of the fieldwork was carried out in the framework of the second MOPP-Medflood project (INQUA CMP 1603P) meeting in Palau (Sardinia, September 2017) . MV is funded by the Rita Levi Montalcini programme of the Italian Ministry of University and Research (MIUR). This article contributes to the PCR "Approche géeoarcheologique des paysages de Corse à l'Holocene, entre mer et interieur des terres «Tra Mare e Monti »" and "Bouches de Bonifacio" research programmes, funded by the DRAC Corsica and directed by Matthieu Ghilardi and Gael 
Brkojewitsch, respectively. It is also part of the MISTRALS-PALEOMEX programme of CNRS (INEEINSU scientific departments) and was funded by the ARCHEOMED workshop (Dir. Laurent Lespez). Finally, this project contributes to the project "Cambiamenti climatici e neotettonica - la Sardegna un continente semi-stabile” (L.R. 7/2007 - Unità operativa Università degli Studi di Cagliari) and to the O.C.E.A.N.S. project (Osservatorio Coste E Ambiente Naturale Sottomarino tra Università di Cagliari, Trieste e Provincia di Sassari) both directed by Prof. Sandro DeMuro. Suggestions made by Prof. Gösta Hoffman (University of Bonn) and Dr Elodie Brisset (CNRS IMBE) improved the earlier version of the manuscript. We also extend our gratitude to the PALSEA (INQUA c ad PAGES working group, the latter supported by the Swiss Academy of Sciences and the Chinese Acade ny \& S Sciences) and IGCP Project 639 communities for fruitful discussions during the workshops.

Bibliography

Antonioli, F., Lon Presti, V., Morticelli, M. G., Bonfiglio, L., ’ ‘nnino, M. A., Palombo, M. R., Canese, S. 2016. Timing of the emergence of the Europe-Sicily all ge (40-17 cal ka BP) and its implications for the spread of modern humans. Geological Society, Lond ^ 1, دuecial Publications, 411(1), 111-144.

Amorosi, A., Maselli, V., Trincardi, F. 2016. r 'nst sre to offshore anatomy of a late Quaternary source-tosink system (Po Plain-Adriatic Sea, Italy). Farth-Scince Reviews, 153, 212-237.

Amorosi, A., Rossi, V., Scarponi, D., Vair i. S. C., Ghosh, A., 2014. Biosedimentary record of postglacial coastal dynamics: high-resolution sequence stratigraphy from the nortern Tuscan coast (Italy). Boreas 43, 939-954.

Athersuch, J., Horne, D.J. and Whiı 'ker, J.E. 1989. Marine and brackish water ostracods, in: Synopses of the British Fauna (New 5 Seri s, 13, Kermack, D.M. and Barnes, R.S.K. (Eds.), Brill E.J., Leiden, 345 pp.

Benjamin J., Rovere, A., Font ‘na, A., Furlani, S., Vacchi, M., Inglis, R., Galili, E., Antonioli, F., Sivan, D. Miko, S., Felja, I., Meredith-Williams, M., Goodman, B., Anzidei, M., Gehrels, R. 2017. Late Quaternary sea-level change and early human societies in the central and eastern Mediterranean Basin: an interdisciplinary review. Quaternary International 449, 29-57.

Boetto, G. 2012. Les épaves comme sources pour l'étude de la navigation et des routes commerciales: une approche méthodologique. Rome, portus and the Mediterranean, 153-173.

Brisset, E., Burjachs, F., Navarro, B. J. B., de Pablo, J. F. L. 2018. Socio-ecological adaptation to EarlyHolocene sea-level rise in the western Mediterranean. Global and planetary change, 169, 156-167.

Bruno, L., Campo, B., Costagli, B., Stouthamer, E., Teatini, P., Zoccarato, C., Amorosi, A. 2020. Factors controlling natural subsidence in the Po Plain. Proceedings of the International Association of Hydrological Sciences, 382, 285-290. 
Buosi, C., Châtelet, E. A. D., Cherchi, A. (2012). Benthic foraminiferal assemblages in the currentdominated Strait of Bonifacio (Mediterranean Sea). The Journal of Foraminiferal Research, 42(1), 39-55.

Buurman, P., Pape, T., Muggler C.C. 1996. Laser grain-size determination in soil genetic studies: Practical problems. Soil Science 162 (3), 211-218.

Carmignani, L., Oggiano, G., Funedda, A., Conti, P., Pasci, S. 2016. The geological map of Sardinia (Italy) at 1:250,000 scale. Journal of Maps, 12(5), 826-835.

Chelli, A., Pappalardo, M., Bini, M., Brückner, H., Neri, G., Neri, M., Spada, G. 2017. Assessing tectonic subsidence from estimates of Holocene relative sea-level change: An example from the NW Mediterranean (Magra Plain, Italy). The Holocene, 27(12), 1988-1999.

Cherry, J. F., Leppard, T. P. 2018. Patterning and its causatior In the pre-Neolithic colonization of the Mediterranean islands (Late Pleistocene to Early Holocene). Tr Jounlal of Island and Coastal Archaeology, 13(2), 191-205.

Cucco, A., Sinerchia, M., Ribotti, A., Olita, A., Faziol, 1., Perilli, A., Sorgente, R. 2012. A high-resolution real-time forecasting system for predicting the $f$ re $u$ oil spills in the Strait of Bonifacio (western Mediterranean Sea). Marine pollution bulletin, 4(6, 1186-1200.

Currás, A., Ghilardi, M., Peche-Quilichini, K., Fagel, N., Vacchi, M., Delanghe, D., Ottaviani, J. C. 2017. Reconstructing past landscapes of the east rr plain of Corsica (NW Mediterranean) during the last 6000 years based on molluscan, sedimento- gicaı and palynological analyses. Journal of Archaeological Science: Reports, 12, 755-769.

Dawson, H., 2011. Island colr nisa ion: Settling the Neolithic question N. Phoca-Cosmetatou (Ed.), The First Mediterranean Islanders: Inli 11 uccupation and Survival Strategies, vol. 74, University of Oxford School of Archaeology, Monograph, pr. J1-54

Dawson, H. 2016. Mediterranean voyages: The archaeology of island colonisation and abandonment. Mediterranean Voyages: The Archaeology of Island Colonisation and Abandonment. Institute of Archaelogical Publications 62vol. 400, Left Coast Press

De Boer, B., Stocchi, P., Van De Wal, R. 2014. A fully coupled 3-D ice-sheet-sea-level model: algorithm and applications. Geoscientific Model Development, 7(5), 2141-2156.

De Falco, G., De Muro, S., Batzella, T., Cucco, A. 2011. Carbonate sedimentation and hydrodynamic pattern on a modern temperate shelf: The strait of Bonifacio (western Mediterranean). Estuarine, Coastal and Shelf Science, 93(1), 14-26. 
De Muro, S., Batzella, T., De Falco, G., Porta, M., 2010. Sedimentological map of Bonifacio Strait inner shelf. Rendiconti Online Società Geologica Italiana, 11(2), 752-753.

De Muro, S. 1990. Dinamica dei litorali e Geomorfologia della Piattaforma prossimale tra Capo Testa e Punta di li Francesi (Sardegna settentrionale). Phd thesis, University of Trieste. 526 pp.

De Muro, S., Orrù, P. 1998. Il contributo delle Beach-Rock nello studio della risalita del mare olocenico. Le Beach-Rock post-glaciali della Sardegna nord-orientale. Il Quaternario 11(1), 19-39.

Desruelles, S., Fouache, É., Ciner, A., Dalongeville, R., Pavlopoulos, K., Kosun, E., Coquinot, Y., Potdevin, J. L. 2009. Beachrocks and sea level changes since Middle Holocene: romparison between the insular group of Mykonos-Delos-Rhenia (Cyclades, Greece) and the southern cost ¿ Change, 66(1-2), 19-33.

D’Orefice, M., Bellotti, P., Bertini, A., Calderoni, G., Censi 1 ‘ri, P., Di Bella, L., ... Vittori, C. 2020. Holocene Evolution of the Burano Paleo-Lagoon (Southern ' 'Isca ly, Italy). Water, 12(4), 1007.

Engelhart, S. E., Vacchi, M., Horton, B. P., Nelson, A F.., Kopp, R. E. 2015. A sea-level database for the Pacific coast of central North America. Quaterna? S : ence Reviews 113, 78-92.

Faccenna, C., Becker, T. W., Auer, L., Billi, A., Boschi, L., Brun, J.P., Capitanio, F.A., Funiciello, F., Horvàth, F., Jolivet L., Piromallo, C., Roy'a n, L., Rossetti, F., Serpelloni, E. 2014. Mantle dynamics in the Mediterranean. Reviews of Geophysics 5?,3, ‘.83-332.

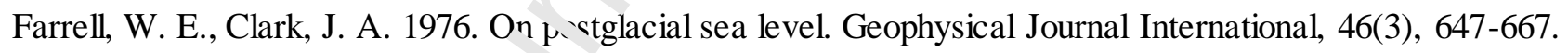

Fitzhugh, B., Hunt, T. L. 199- In 'oduction: Islands as laboratories: Archaeological research in comparative perspective. Human Ecology, $2 / y-383$.

Furlani, S., Pappalardo, M., Gómez-Pujol, L., Chelli, A. 2014. The rock coast of the Mediterranean and Black seas. Geological Society, London, Memoirs, 40(1), 89-123.

Gérigny, O., Coudray, S., Lapucci, C., Tomasino, C., Bisgambiglia, P. A., Galgani, F. 2015. Small-scale variability of the current in the Strait of Bonifacio. Ocean Dynamics, 65(8), 1165-1182.

Ghilardi, M., Istria, D., Curras, A., Vacchi, M., Contreras, D., Vella, C., Dussouillez, P., Crest, Y., Guiter, F., Delanghe, D. 2017. Reconstructing the landscape evolution and the human occupation of the Lower Sagone River (Western Corsica, France) from the Bronze Age to the Medieval period. Journal of Archaeological Science: Reports, 12, 741-754. 
Ghilardi M., Lespez L., 2017. Geoarchaeology of the Mediterranean islands: from « Lost worlds » to vibrant places. In Ghilardi M. and Lespez L. (eds.), Geoarchaeology of the Mediterranean islands, Journal of Archaeological Science: Reports, 12, 735-740

Giaime, M., Morhange, C., Ontiveros, M. Á. C., Fornós, J. J., Vacchi, M., Marriner, N. 2017. In search of Pollentia's southern harbour: Geoarchaeological evidence from the Bay of Alcúdia (Mallorca, Spain). Palaeogeography, palaeoclimatology, palaeoecology, 466, 184-201.

Guillot, F. 1997. La grotta di Sant Elmo o" Grotta Verde" in Alghero. Revista de l'Alguer, 8(8), 81-92.

Heiri, O., Lotter, A.F., Lemcke, G., 2001. Loss on ignition as a method for estimating organic and carbonate content in sediments: reproducibility and comparability of results. Journal or Paleolimnology 25, 101-110.

Hijma, M., Engelhart, S.E., Tornqvist, T.E., Horton, B.P., Hu, P., Hill, J., 2015. A protocol for a geological sea-level database. In: Shennan, I., Long, A., Horton, B.P. (Eds.' Handbook of Sea Level Research. Wiley, pp. 536-553.

Iacono, R., Napolitano, E., Marullo, S., Artale, V., and V.tr no, A.: Seasonal variability of the tyrrhenian sea surface geostrophic cir- culation as assessed by $a^{\text {k: }}$.

Karkani, A., Evelpidou, N., Vacchi, M., M-rrhange, C., Tsukamoto, S., Frechen, M., Maroukian, H. 2017. Tracking shoreline evolution in central Cyc' ${ }^{\prime}$ des 'Greece) using beachrocks. Marine Geology, 388, 25-37.

Khan, N. S., Ashe, E., Shaw, T. A., ' 'cchı, M., Walker, J., Peltier, W. R., Kopp, R.E., Horton, B. P. 2015. Holocene Relative Sea-Level Change. from Near-, Intermediate-, and Far-Field Locations. Current Climate Change Reports 1(4), 247-262.

Khan, N. S., Horton, B. P., E. reınart, S., Rovere, A., Vacchi, M., Ashe, E. L., Shennan, I. 2019. Inception of a global atlas of sea levels sime the Last Glacial Maximum. Quaternary Science Reviews, 220, 359-371.

Laborel, J., Morhange, C., Lafont, R., Le Campion, J., Laborel-Deguen, F., Sartoretto, S. 1994. Biological evidence of sea-level rise during the last 4500 years on the rocky coasts of continental southwestern France and Corsica. Marine Geology 120(3), 203-223.

Lambeck, K., Purcell, A. 2005. Sea-level change in the Mediterranean Sea since the LGM: model predictions for tectonically stable areas. Quaternary Science Reviews, 24(18-19), 1969-1988.

Lambeck, K., Antonioli, F., Anzidei, M., Ferranti, L., Leoni, G., Scicchitano, G., Silenzi, S. 2011. Sea level change along the Italian coast during the Holocene and projections for the future. Quaternary International, 232(1-2), 250-257. 
Lambeck, K., Rouby, H., Purcell, A., Sun, Y., Sambridge, M. 2014. Sea level and global ice volumes from the Last Glacial Maximum to the Holocene. Proceedings of the National Academy of Sciences 111(43), 15296-15303.

Le Bourdonnec, F. X., Poupeau, G., Lugliè, C., D’Anna, A., Bellot-Gurlet, L., Bressy-Leandri, C. S., Pasquet, A., Tramoni, P. 2011. New data and provenance of obsidian blocks from Middle Neolithic contexts on Corsica (western Mediterranean). Comptes Rendus Palevol 10(4), 259-269.

Lewthwaite, J. 1990. Isolating the residuals: The Mesolithic basis of man-animal relationships on the Mediterranean islands. The Mesolithic in Europe. International Symposium 3. pp. 541-555.

Lo Schiavo, F., 1987. Grotta Verde 1979: un contributo sul neolitico anticu della Sardegna Atti della XXVI Riunione Scientifica dell'Istituto Italiano di Preistoria e Protostoria, pp. $845 \pm 858$.

Lo Presti, V., Antonioli, F., Palombo, M.R., Agnesi, V., b. ılchi, S., Calcagnile, L., Pepe, F. 2019. Palaeogeographical evolution of the Egadi Islands (wester: Sic y, Italy). Implications for late Pleistocene and early Holocene sea crossings by humans and other namnals in the western Mediterranean. EarthScience Reviews 194, 160-181

Lugliè, C. 2018. Your path led trough the su .. the emergence of Neolithic in Sardinia and Corsica. Quaternary International, 470, 285-300.

Marriner, N., Gambin, T., Djamali, M.. Mo.h`.nge, C., Spiteri, M. 2012. Geoarchaeology of the Burmarrad ria and early Holocene human in ${ }_{1}$ 'רcts in western Malta. Palaeogeography, Palaeoclimatology, Palaeoecology, 339, 52-65.

Marriner, N., Flaux, C., Mor ang :, C., Kaniewski, D. 2012. Nile Delta's sinking past: Quantifiable links with Holocene compaction anu zlimate-driven changes in sediment supply?. Geology, 40(12), 1083-1086.

Marriner, N., Morhange, C., Faivre, S., Flaux, C., Vacchi, M., Miko, S., Rossi, I. R. 2014. Post-Roman sealevel changes on Pag Island (Adriatic Sea): Dating Croatia's "enigmatic" coastal notch? Geomorphology 221, 83-94.

Mauz, B., Vacchi, M., Green, A., Hoffmann, G., Cooper, A. 2015. Beachrock: A tool for reconstructing relative sea level in the far-field. Marine Geology 362, 1-16.

Marco-Barba, J., Holmes, J. A., Mesquita-Joanes, F., Miracle, M. R. 2013. The influence of climate and sealevel change on the Holocene evolution of a Mediterranean coastal lagoon: evidence from ostracod palaeoecology and geochemistry. Geobios, 46(5), 409-421. 
Milne, G. A., Mitrovica, J. X. 1998. Postglacial sea-level change on a rotating Earth. Geophysical Journal International 133(1), 1-19.

Milne, G.A., Long, A.J., Bassett, S.E., 2005. Modeling Holocene relative sea-level observations from the Caribbean and South America. Quaternary Science Reviews 24, 1183-1202.

Medail F., 2017. The specific vulnerability of plant biodiversity and vegetation on Mediterranean islands in the face of global change. Regional Environmental Change, Springer Verlag, 17 (6),1775-1790.

Medas, S. 2005. La navigazione di Posidonio dall'Iberia all'Italia e le rotte d'altura nel Mediterraneo occidentale in età romana. Mayurqa, 30(2), 577-610.

Melini, D., Spada, G. 2019. Some remarks on Glacial Isostatic Ao ustment modelling uncertainties. Geophysical Journal International, 218(1), 401-413.

Modi, A., Tassi, F., Susca, R. R., Vai, S., Rizzi, E., De Bell s, G Lugliè, C., Gonzales Fortes, G., Lari, M., Barbujani, G., Caramelli, D., Ghirotto, S., 2017. Comp'ste mitochondrial sequences from Mesolithic Sardinia. Scientific reports, 7, 42869

Montefalcone, M., Vacchi, M., Carbone, C., ( abe la, R., Schiaffino, C. F., Elter, F. M., Morri, C., Bianchi, C.n., Ferrari, M. 2016. Seagrass on the rc ks: Posidonia oceanica settled on shallow-water hard substrata withstands wave stress beyond predictions. - _ctua -ine, Coastal and Shelf Science, 180, 114-122.

Morhange, C., Marriner, N., Excoffc. P., Bonnet, S., Flaux, C., Zibrowius, H., ... Amouri, M. E. 2013. Relative sea-level changes during Ru nan times in the northwest Mediterranean: The 1st century AD fish tank of Forum Julii, Fréjus, Franc. Gr oarchaeology, 28(4), 363-372.

Morhange, C., Pirazzoli, P. A. Marriner, N., Montaggioni, L. F., Nammour, T. 2006. Late Holocene relative sea-level changes in Lebanon, Eastern Mediterranean. Marine Geology, 230(1-2), 99-114.

Nesteroff, W. D. 1984. Étude de quelques grès de plage du sud de la Corse: datations ${ }^{14} \mathrm{C}$ et implications néotectoniques pour le bloc corso-sarde. Travaux de la Maison de l'Orient 8(1), 99-111.

Nocquet, J. M. 2012. Present-day kinematics of the Mediterranean: A comprehensive overview of GPS results. Tectonophysics, 579, 220-242.

Oggiano, G., Funedda, A., Carmignani, L., Pasci, S. 2009. The Sardinia-Corsica microplate and its role in the Northern Apennine Geodynamics: new insights from the Tertiary intraplate strike-slip tectonics of Sardinia. Bollettino della Società Geologica Italiana, 128(2), 527-539. 
Olita, A., Iermano, I., Fazioli, L., Ribotti, A., Tedesco, C., Pessini, F., Sorgente, R. 2015. Impact of currents on surface flux computations and their feedback on dynamics at regional scales. Ocean Science, 11(4).

Opdebeeck, J. 2005. Shipwrecks and amphorae: Their relationship with trading routes and the Roman economy in the Mediterranean (Doctoral dissertation, University of Southampton). 59 pp.

Ozer, A., Tucci, S., Ulzega, A. 1984. Les beach-rocks de Sardaigne. Distribution et implications paléogéographiques. MOM Éditions, 8(1), 113-124.

Palombo, M.R., Antonioli, F., Lo Presti, V., Mannino, M.A., Melis, R.T., Orru, P., Stocchi, P., Talamo, S., Quarta, G., Calcagnile, L., Deiana, G., 2017. The Late Pleistocene to Holocene palaeogeographic evolution of the Porto Conte area: clues for a better understanding of human coinisation of Sardinia and faunal dynamics during the last $30 \mathrm{ka}$. Quaternary International, 439,117-140.

Peltier, W.R., 2004. Global glacial isostasy and the surface of the "se-age earth: the ice-5G (VM2) model and grace. Annual Review of Earth and Planetary Sciences 32, 1 1-1< 7.

Peltier, W. R., Argus, D. F., Drummond, R. 2015. Sp ic $<$; eodesy constrains ice age terminal deglaciation:

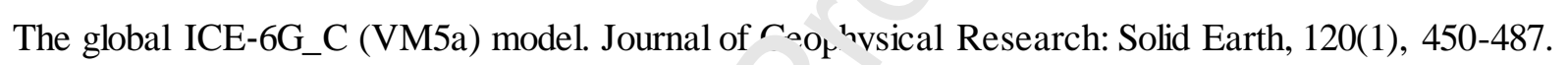

Péres, J.-M., 1982. Major benthic assemb!^ges. In. Kinne, O. (Ed.), Marine Ecology, vol. 5, part 1. Wiley, Chichester, pp. 373-522.

Péres, J.-M., Picard, J., 1964. Nouvea: manuel de bionomie benthique de la mer Méditerranée. Recherche et travaux de la Station Marine Endorme, vol. 31. Marseille.

Pirazzoli, P. A. 2005. A re iew of possible eustatic, isostatic and tectonic contributions in eight lateHolocene relative sea-level $h_{\iota}{ }^{\text {tores }}$ from the Mediterranean area. Quaternary Science Reviews, 24(18-19), 1989-2001.

Reimer, P.J., Bard, E., Bayliss, A., Beck, J.W., Blackwell, P.G., Bronk Ramsey, C.,Buck, C.E., Cheng, H., Edwards, R.L., Friedrich, M., Grootes, P.M., Guilderson, T.P., Haflidason, H., Hajdas, I., Hatta, C., Heaton, T.J., Hogg, A.G., Hughen, K.A., Kaiser, K.F., Kromer, B., Manning, S.W., Niu, M., Reimer, R.W., Richards, D.A.,Scott, E.M., Southon, J.R., Turney, C.S.M., van der Plicht, J., 2013. IntCal13 andMARINE13 radiocarbon age calibration curves 0-50000 years cal BP. Radiocarbon 55.http://dx.doi.org/10.2458/azu_js_rc.55.16947

Revelles, J., Ghilardi, M., Rossi, V., Currás, A., López-Bultó, O., Brkojewitsch, G., Vacchi, M. 2019. Coastal landscape evolution of Corsica island (W. Mediterranean): palaeoenvironments, vegetation history and human impacts since the early Neolithic period. Quaternary Science Reviews, 225, 105993 
Reynolds, P. 2010. Hispania and the Roman Mediterranean, AD 100-700: ceramics and trade (p. 120156). London: Duckworth.

Rovere, A., Parravicini, V., Vacchi, M., Montefalcone, M., Morri, C., Bianchi, C. N., Firpo, M. 2010. Geoenvironmental cartography of the marine protected area "Isola di Bergeggi"(Liguria, NW Mediterranean Sea). Journal of Maps 6(1), 505-519.

Rossi, V., Amorosi, A., Sarti, G., Potenza, M. 2011. Influence of inherited topography on the Holocene sedimentary evolution of coastal systems: an example from Arno coastal plain (Tuscany, Italy). Geomorphology, 135(1-2), 117-128.

Rossi, V., Amorosi, A., Sarti, G., Mariotti, S., 2017. Late Quaternarı mı Itiple incised valley systems: an unusually well-preserved stratigraphic record of two interglacial valle, -fi'. successions from the Arno plain (northern Tuscany, Italy). Sedimentology 64, 1901-1928.

Roy, K., Peltier, W. R. 2018. Relative sea level in the Wes 'rn I Tediterranean basin: A regional test of the ICE-7G_NA (VM7) model and a constraint on Late Holo ene s.ntarctic deglaciation. Quaternary Science Reviews, 183, 76-87.

Secci, M., Giarrusso, C., Nieddu, G., Porqueddu, '.., Spanu, P. 2013. The Maddalena Archipelago Maritime Target Survey: A Collaborative Effort towa ${ }^{-1}$ the Enhancement of Maritime Cultural Heritage. Underwater Archaeology Proceedings 2013. 93-103.

Salel, T., Bruneton, H., Lefèvre, D $\iota^{\top} 16$. Ostracods and environmental variability in lagoons and deltas along the north-western Mediterra 'ea coast (Gulf of Lions, France and Ebro delta, Spain). Revue de Micropaléontologie, 59(4), 425-44i.

Serpelloni, E., Faccenna, C., s ada, G., Dong, D., Williams, S. D. 2013. Vertical GPS ground motion rates in the Euro-Mediterranean region: New evidence of velocity gradients at different spatial scales along the Nubia-Eurasia plate boundary. Journal of Geophysical Research: Solid Earth 118(11), 6003-6024.

Shackleton, J. C., Van Andel, T. H., Runnels, C. N. 1984. Coastal paleogeography of the central and western Mediterranean during the last 125,000 years and its archaeological implications. Journal of field Archaeology, 11(3), 307-314.

Shennan, I. 1986. Flandrian sea-level changes in the Fenland. II: Tendencies of sea-level movement, altitudinal changes, and local and regional factors. Journal of Quaternary Science 1(2), 155-179.

Shennan, I., Long, A. J., Horton, B. P. 2015. Handbook of sea-level research. John Wiley \& Sons. 
Shennan, I., Horton, B., 2002. Holocene land- and sea-level changes in Great Britain. Journal of Quaternary Science 17, 511-526.

Siani, G., Paterne, M., Michel, E., Sulpizio, R., Sbrana, A., Arnold, M., Haddad, G. 2001. Mediterranean Sea surface radiocarbon reservoir age changes since the last glacial maximum. Science 294(5548), 1917-1920.

Sornoza, L., Barnolas, A., Arasa, A., Maestro, A., Rees, J. G., Hernández-Molina, F. J. 1998. Architectural stacking patterns of the Ebro delta controlled by Holocene high-frequency eustatic fluctuations, delta-lobe switching and subsidence processes. Sedimentary Geology, 117(1-2), 11-32.

Sorgente, B., Sorgente, R., Olita, A., Fazioli, L., Cucco, A., Perilli, A., Sinercha, M., Ribotti, A. 2012. Effects of protection rules and measures in an important international strait a rea: the Bonifacio Strait. Journal of Operational Oceanography, 5(1), 35-44

Spada, G., Antonioli, A., Cianetti, S., Giunchi, C. 2006. Glacía isostatic adjustment and relative sea-level changes: the role of lithospheric and upper mantle hetero 2 neil es in a 3-D spherical Earth. Geophysical Journal International, 165(2), 692-702.

Spada, G., Melini, D. 2019. On Some Propertir - or the Glacial Isostatic Adjustment Fingerprints. Water, 11(9), 1844.

Spada, G., Stocchi, P. 2007. SELEN: A Fr..."an 70 program for solving the "sea-level equation". Computers \& Geosciences 33(4), 538-562.

Stocchi, P., Spada, G. 2009. Influence of glacial isostatic adjustment upon current sea level variations in the Mediterranean. Tectonophysics 4?, (1), 56-68.

Stocchi, P., Vacchi, M., Loı neid, T., de Boer, B., Simms, A. R., van de Wal, R. S., Pappalardo, M., Rovere, A. 2018. MIS 5e relative sea-level changes in the Mediterranean Sea: Contribution of isostatic disequilibrium. Quaternary Science Reviews, 185, 122-134.

Stuiver, M., Polach, H.A., 1977. Reporting ${ }^{14}$ C data. Radiocarbon 19, 355-363.

Tamm, E., Di Cristofaro, J., Mazières, S., Pennarun, E., Kushniarevich, A., Raveane, A., Montinaro, F. 2019. Genome-wide analysis of Corsican population reveals a close affinity with Northern and Central Italy. Scientific reports, 9(1), 1-10.

Thierry, S., Dick, S., George, S., Benoit, L., Cyrille, P. 2019. EMODnet Bathymetry a compilation of bathymetric data in the European waters. In OCEANS 2019-Marseille. pp. 1-7. 
Tomassetti, L., Brandano, M. 2013. Sea level changes recorded in mixed siliciclastic-carbonate shallowwater deposits: The Cala di Labra Formation (Burdigalian, Corsica). Sedimentary Geology, 294, 58-67.

Tornqvist, T.E., Rosenheim, B.E., Hu, P., Fernandez, A.B., 2015. Radiocarbon dating and calibration. In: Shennan, I., Long, A.J., Horton, B.P. (Eds.), Handbook of Sea- level Research. Wiley, pp. 349-360.

Vacchi, M., Ghilardi, M., Melis, R. T., Spada, G., Giaime, M., Marriner, N., Morhange C., Rovere, A. 2018. New relative sea-level insights into the isostatic history of the Western Mediterranean. Quaternary Science Reviews, 201, 396-408.

Vacchi, M., Ghilardi, M., Spada, G., Currás, A., Robresco, S. 2017. Ne w insights into the sea-level evolution in Corsica (NW Mediterranean) since the late Neolithic. Journal of $\Delta \mathrm{rc}_{\text {. }}{ }^{2}$ eological Science: Reports, 12 , $782-793$.

Vacchi, M., Marriner, N., Morhange, C., Spada, G., Fontana, A., Qovere, A. 2016. Multiproxy assessment of Holocene relative sea-level changes in the western Mediter-'nea l: Sea-level variability and improvements in the definition of the isostatic signal. Earth-Science Reviews 155, 172-197.

Vacchi, M., Rovere, A., Zouros, N., Desruelles , Saron, V., Firpo, M. 2012. Spatial distribution of sealevel markers on Lesvos Island (NE Aegean St.') evidence of differential relative sea-level changes and the neotectonic implications. Geomorphology, 1.59, 50-62.

Vacchi, M., Russo Ermolli, E.., Morhanª, ( $\quad$ Ruello, M. R., Di Donato, V., Di Vito, M. A., Giampaola, D., Carsana, V., Liuzza, V., Cinque, A., Roetto, G., Poveda, P., Boenzi, G., Marriner, N. 2019. Millennial variability of rates of sea-level ris in the ancient harbour of Naples (Italy, western Mediterranean Sea). Quaternary Research, 1-15.

Van Andel, T. H. 1989. Late \& taternary sea-level changes and archaeology. Antiquity, 63(241), 733-745.

Vigne, J. D. 1992. Zooarchaeology and the biogeographical history of the mammals of Corsica and Sardinia since the last ice age. Mammal Review, 22(2), 87-96.

Vigne, J.-D., Thibault, J.-C., Cheylan, G., 1994. L'archipel des Lavezzi: présentation, histoire des peuplements, problématiques archéozoologiques. Monographie du CRA 13, pp. 25-42.

Figure, tables and appendix captions:

Figure 1: A) Geographical position of Corsica and Sardinia in the western Mediterranean and approximate location of the palaeoshoreline at the Last Glacial Maximum (LGM, red line). BoS is Bonifacio Strait, EB is Elba Island; CR is Capraia Island. B) Tectonic framework of the study area (modified after Stocchi et al, 
2018), red lines indicate the major faults according to Faccenna et al. (2014). C) Location of the coring sites (red squares) beachrock sampling (white squares). MN is Moines, CL is Cala Lunga, PT is Piantarella, CV is Cavallo, BD is Budelli, CT is Capo Testa and TM is Tanca Manna. Satellite Imagery in panel C) from Google Earth (Google, Maxar Technologies, SIO, NOAA, U.S. Navy, NGA, GEBCO).

Figure 2. A) Geographic position, stratigraphy and ${ }^{14} \mathrm{C}$ dating of the units defined for the Piantarella lagoon cores (P1, P2, P3). B) Geographic position, stratigraphy and ${ }^{14} \mathrm{C}$ dating of the units defined for the Budelli cores (B1, B2, B3). NGF is the French National Geodetic datum which is presently placed $0.12 \mathrm{~m}$ below the msl. In B1 core, the presence of in situ fossil Posidonia oceanica matte, showed. Satellite imagery from Google Earth (Google, 2014).

Figure 3. Spatial extent and bathymetric distribution of the diffe 1 nt beachrock levels measured in Tanca Manna (A, C, D) and Cala Lunga (B, E, F); depth is expresse. in ' 1 below the msl and distance is expressed in $\mathrm{m}$ from the shoreline. The age of the deepest slabs is $: \mathrm{x}^{r} \mathrm{f}^{\mathrm{r}} \mathrm{ssed}$ in calibrated years BP. Thin section (crosspolarized light) of the beachrock samples in Cala $\mathrm{L} \cdot \mathrm{ng}_{\mathrm{u}}(\mathrm{G}, \mathrm{H})$ and Tanca Manna (J,H) a) small bladed isopachous fringe of limpid and contiguous HMC ८ vstals; b) irregularly shaped intertidal micritic cement; c) peloidal cements; d) radial fibrous HMC c2.. ${ }^{+*}$. Natellite imagery from Google Earth (Google, 2014 and Maxar Technologies, 2020).

Figure 4. Holocene RSL reconstruchi $n$ ior the BoS coasts. Red boxes are the sedimentary (sed.) Sea Level Index Points (SLIPs) producer in ' 'is study. Grey boxes are the sedimentary (sed.) SLIPs available in the Vacchi et al., 2018 RSL databa e (V18). Blue filled boxes are the beachrock (bcrk) SLIPs produced in this study. Grey filled boxes are bcrk SLIPs available in the V18 database. Filled blue triangles are the sedimentary Marine Limiting Points (sed. MLPs) produced in this study. Empty blue trinagles are the sed. MLPs available in the V18 database. Dimensions of boxes and lines for each point based on 2s elevation and age errors. The RSL record compared to four GIA predictions: black lines is IC5-5G (VM2), red line is the ICE-6G (VM2), green line is the ANICE-SELEN (VM2) and blue line is K33 (see section 3.5).

Figure 5. Palaeogeographical reconstruction of the BoS shoreline position (red line) at $\sim 10 \mathrm{ka}$ (A), $\sim 9 \mathrm{ka}$ (B), and $\sim 7 \mathrm{ka}(\mathrm{C}) \mathrm{BP}$. Black line indicates the modern shoreline position while red line show the position of the palaeoshoreline. Yellow triangles show the indicative position of Mesolithic settlements while brown 
squares show the early Neolithic setllements (modified from Lugliè, 2018). Mn is Moines bank, cv is

Cavallo Island, lv is Lavezzi Island, sp is Sperduti bank, rz is Razzoli Island, $\mathrm{mr}$ is Santa Maria Island, bd is

Budelli Island, br is Berrettini bank, sp is Spargi, md is La Maddalena Island, st is Santo Stefano Island, cp is Caprera Island, bs is Bisce bank.

Table 1. The new dataset of Sea-Level Index Points (SLIP) and Marine Limiting Points (MLP) from the Bonifacio Strait. P is Piantarella (core 1, 2 and 3); B is Budelli (core 1,2 and 3); TC is Tanca Manna; CL is Cala Lunga. IR is the Indicative range. Elevation is expressed in $\mathrm{m}$ above mean sea level (msl). The final error includes the sampling and leveling errors and, for SLIPs, the indic tive range.

Table 2. Sea Level Index Points (SLIP) and Marine Limiting Pc nts MLP) from the Bonifacio Strait extracted from the V18 database (Vacchi et al., 2018).

Appendix 1. Results of the grain-size analysis performed on th - Qu' 'elli cores.

\section{Highlights}

An analysis of the postglacial evolution the Bonifacio st." it

The Bonifacio strait is a key coastal area of we terr Mediterranean

New insights into the timing of progressive $\iota_{2}$ nening of the strait were provided Major paleogeographic changes occurred $l \mathrm{e}^{f} \mathrm{or} \sim \sim 7 \mathrm{ka}$ BP

Sea-level rose with rates $\leq 0.35 \mathrm{~mm} \mathrm{a}^{-\cdots}$ n the last four millennia

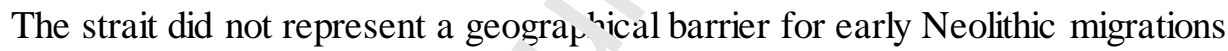




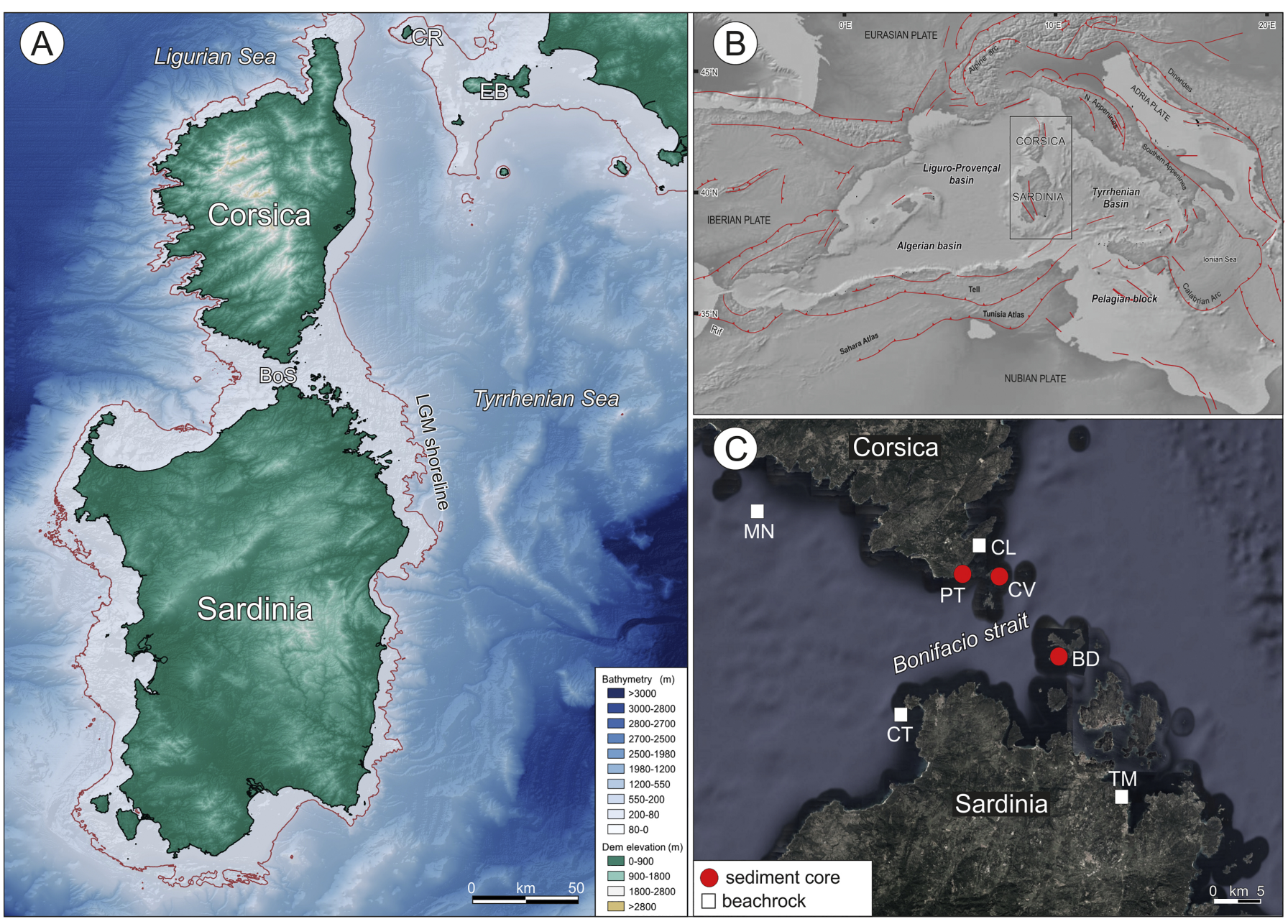

Figure 1 


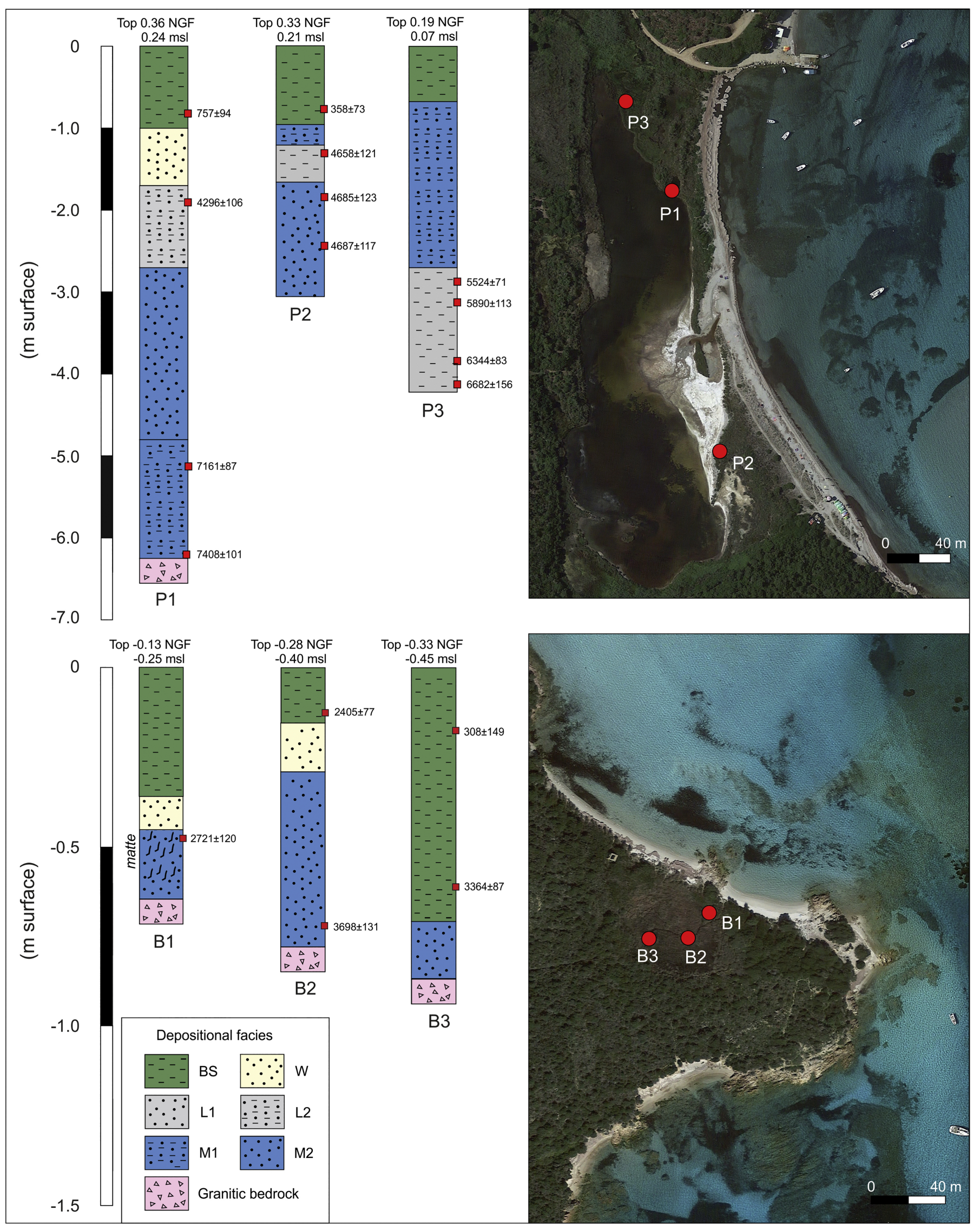




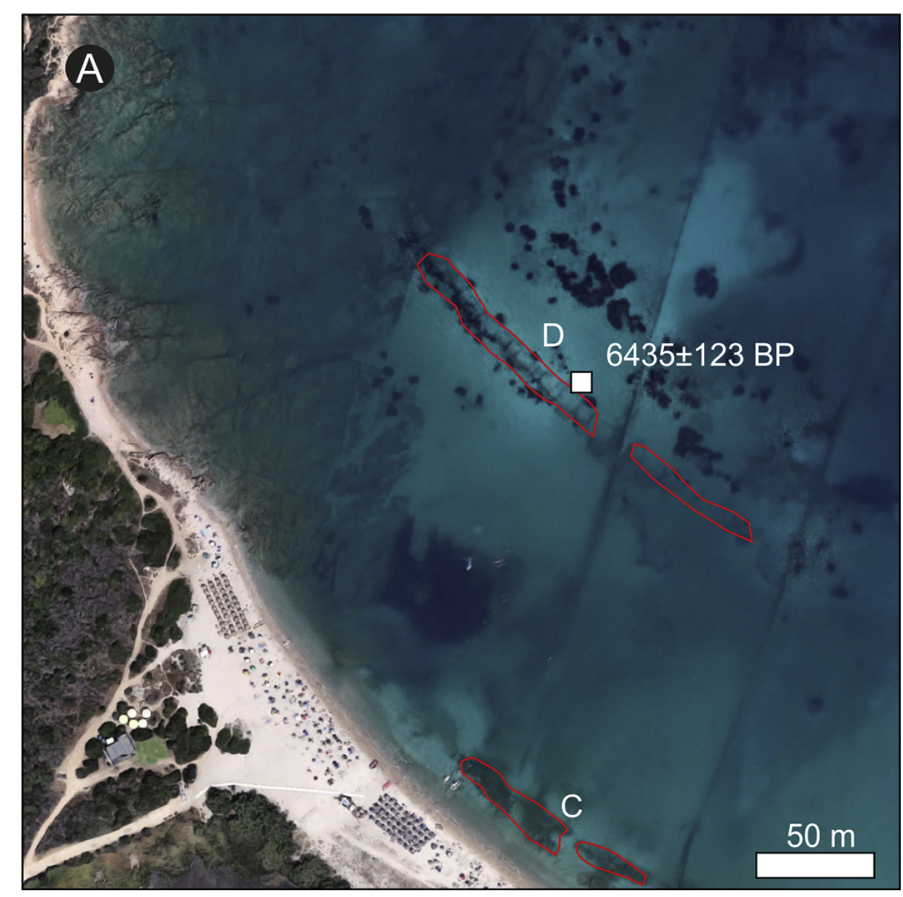

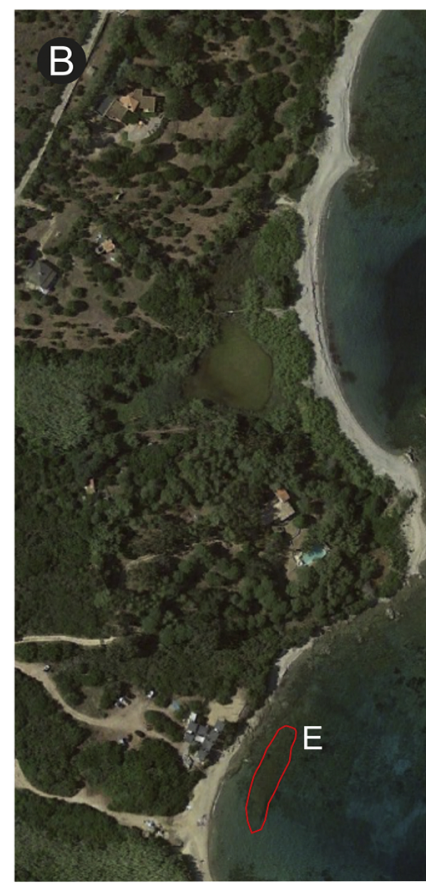

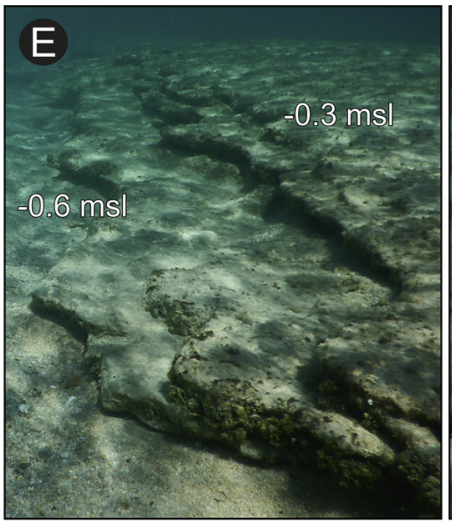

$-3.6 \mathrm{~ms}$

$-4.1 \mathrm{msl}$

D

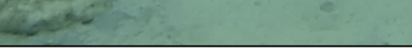

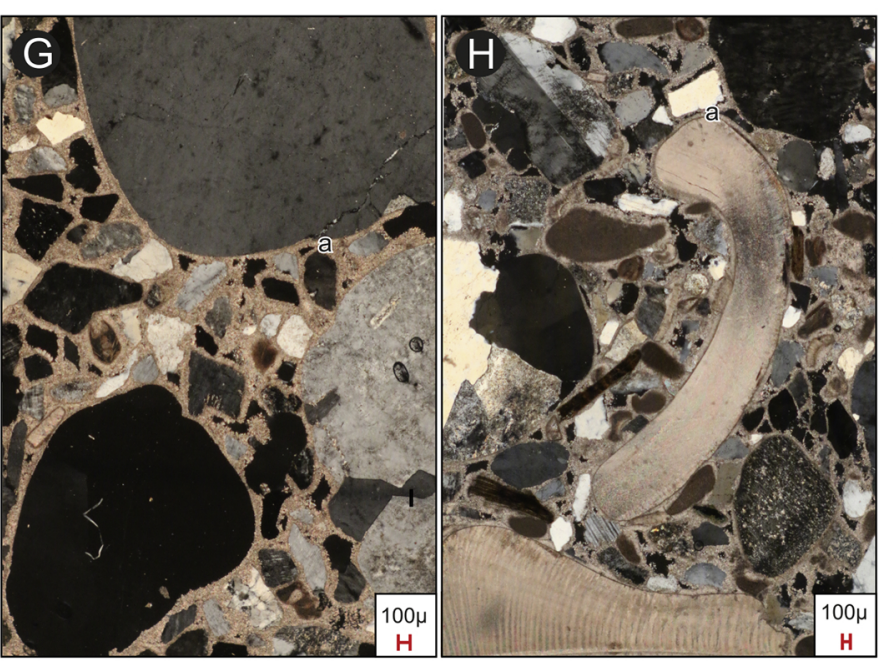

$6307 \pm 97 \mathrm{BP}$ F

$50 \mathrm{~m}$
F

$-3.4 \mathrm{msl}$

re?

$-3.8 \mathrm{~ms}$

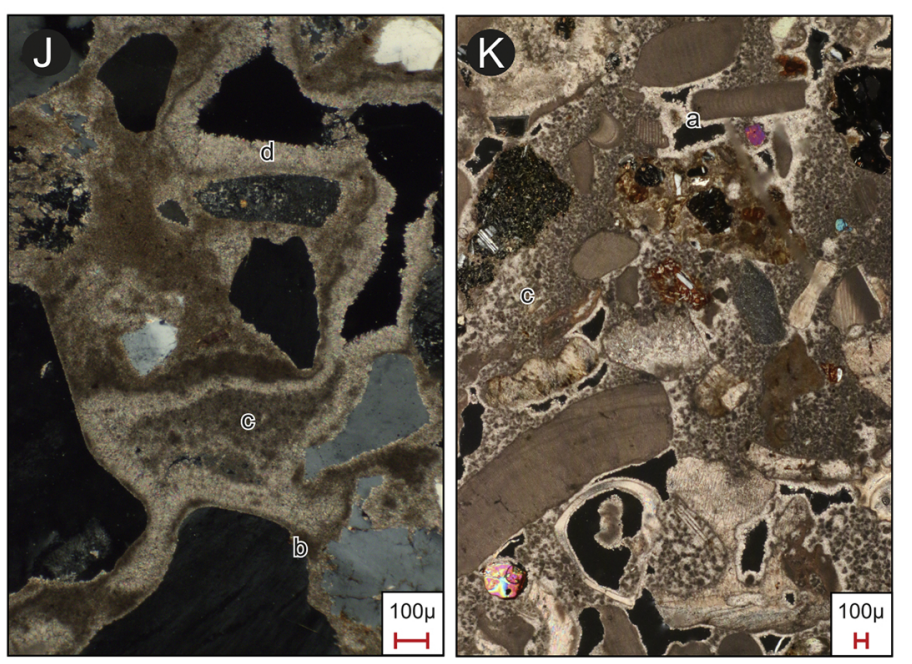

Figure 3 


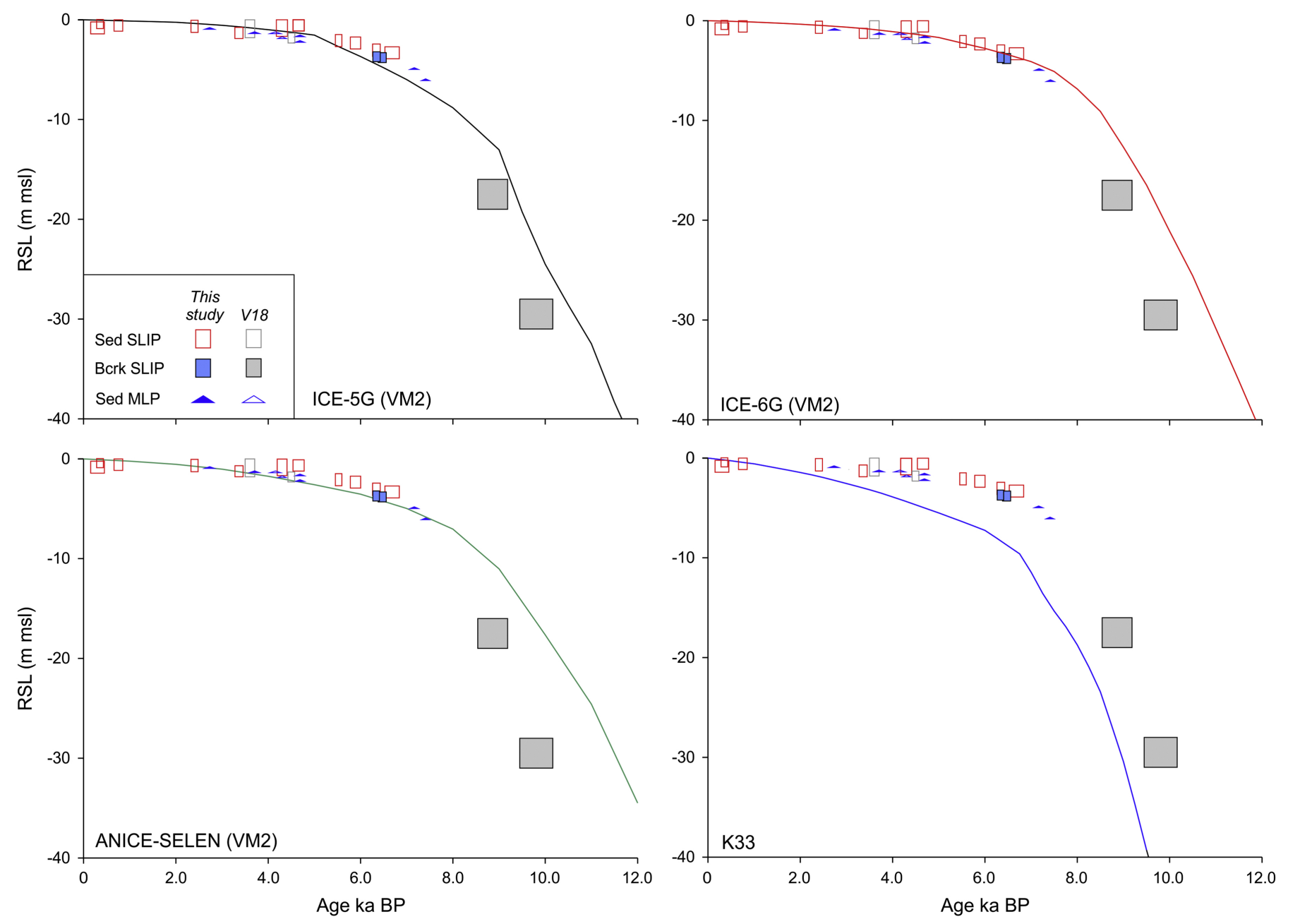

Figure 4 


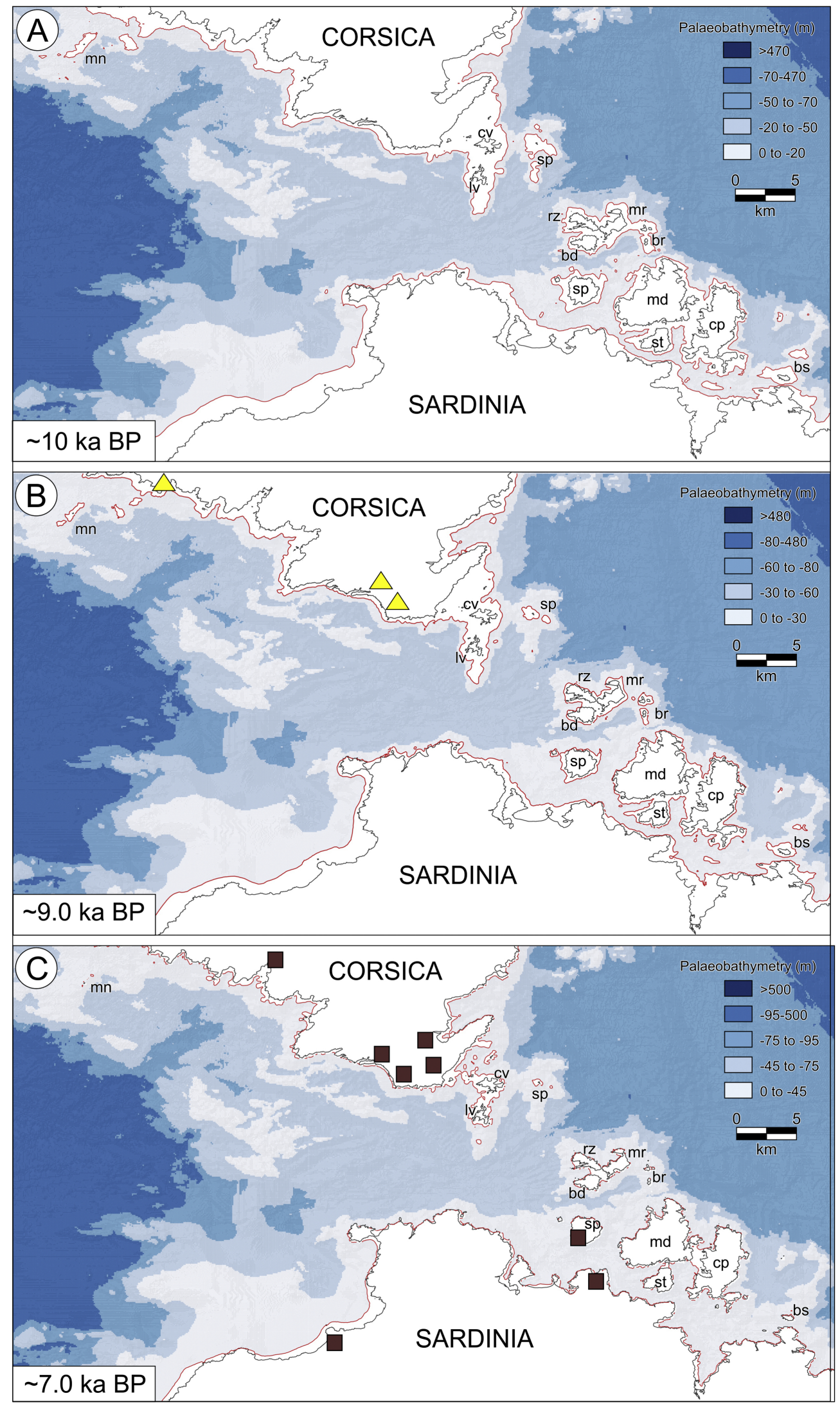

